\title{
Repository Disposal
}

Requirements for Commercial

Transuranic Wastes (Generated

without Reprocessing)
P. M. Daling
J. D. Ludwick
G. B. Mellinger
R. W. McKee

June 1986

Prepared for the U.S. Department of Energy under Contract DE-AC06-76RLO 1830

Pacific Northwest Laboratory Operated for the U.S. Department of Energy by Battelle Memorial Institute 


\title{
DISCLAIMER
}

This report was prepared as an account of work sponsored by an agency of the United States Government. Neither the United States Government nor any agency thereof, nor any of their employees, makes any warranty, express or implied, or assumes any legal liability or responsibility for the accuracy, completeness, or usefulness of any information, apparatus, product, or process disclosed, or represents that its use would not infringe privately owned rights. Reference herein to any specific commercial product, process, or service by trade name, trademark, manufacturer, or otherwise, does not necessarily constitute or imply its endorsement, recommendation, or favoring by the United States Government or any agency thereof. The views and opinions of authors expressed herein do not necessarily state or reflect those of the United States Government or any agency thereof.

\author{
PACIFIC NORTHWEST LABORATORY \\ operated by \\ BATTELLE \\ for the \\ UNITED STATES DEPARTMENT OF ENERGY \\ under Contract DE-AC06-76RLO 1830
}

\begin{tabular}{|c|c|}
\hline \multirow{2}{*}{\multicolumn{2}{|c|}{ Printed in the United States of America }} \\
\hline & \\
\hline \multicolumn{2}{|c|}{ National Technical Information Service } \\
\hline \multicolumn{2}{|c|}{ United States Department of Commerce } \\
\hline \multicolumn{2}{|c|}{ S285 Port Royal Road } \\
\hline \multicolumn{2}{|c|}{ Springfield, Virginia 22161} \\
\hline \multirow{2}{*}{\multicolumn{2}{|c|}{$\begin{array}{l}\text { NTIS Price Codes } \\
\text { Microfiche A01 }\end{array}$}} \\
\hline & \\
\hline \multicolumn{2}{|c|}{ Printed Copy } \\
\hline & \\
\hline Pages & Codes \\
\hline $001-025$ & $\mathrm{~A} 02$ \\
\hline 026-050 & $\wedge 03$ \\
\hline 051-075 & A04 \\
\hline $076-100$ & A05 \\
\hline $101-125$ & A06 \\
\hline $126-150$ & $\mathrm{~A} 07$ \\
\hline $151-175$ & $A 08$ \\
\hline $176-200$ & $A 09$ \\
\hline $201-225$ & $\wedge 010$ \\
\hline $226-250$ & A011 \\
\hline $251-275$ & A012 \\
\hline $276-300$ & A013 \\
\hline
\end{tabular}


REPOSITORY DISPOSAL REQUIREMENTS FOR COMMERCIAL TRANSURANIC WASTES

(GENERATED WITHOUT REPROCESSING)

P. M. Daling

J. D. Ludwick

G. B. Mellinger

R. W. McKee

June 1986

Prepared for

the U.S. Department of Energy

under Contract DE-ACO6-76RLO 1830

Pacific Northwest Laboratory

Richland, Washington 99352 
.

•,

.

.

\author{
.
}




\begin{abstract}
PREFACE
The following report was fundeo jointly by the Department of Energy (DOE) Office of Civilian Radioactive Waste Management (OCRWM) and Office of Nuciear Energy (NE). The portions funded by DOE-OCRWM were managed through the Systems, Transportation and Waste Fund Studies Program Office at Pacific Northwest Laboratory (PNL). Portions funded by DOE-NE were managed through the Commercial Nuclear Waste Treatment Program Office, al so at PNL.

This report proposes waste acceptance requirements for disposal of transuranic (TRU) wastes in a geologic repository. The proposed requirements are intended to ensure the safe and economic disposal of these wastes. These requirements are based on existing information regarding repository-mediaspecific waste emplacement conditions and waste-package design specifications. Repository and waste-package design activities are on-going and final designs will not be completed for several years. As a result, the basis for some of the proposed requirements discussed in this document will change as additional media-specific data are obtained. Comments from an external review of a draft version of this report have been accommodated to the maximum extent possible. However, some of the issues that were raised during the review process can only be addressed by significant additional studies, such as complex thermal analyses of the repositories or experimental programs with waste materials. These issues are identified, where appropriate, in the report. The DOE is planning further studies to update and revise these TRU waste acceptance requirements after additional data becomes available. These proposed requirements are thus subject to revision in the future and, as such, should not be construed as final.
\end{abstract}




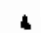

\section{.}

,
$\bullet$

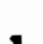

+
$\ldots$ 


\section{EXECUTIYE_SUMMARY}

This report forms a preliminary planning basis for disposal of commercial transuranic (TRU) wastes in a geologic repository. Because of the unlikely prospects for commercial spent nuclear fuel reprocessing in the near-term, this report focuses on TRU wastes generated in a once-through nuclear fuel cycle; (i.e., without fuel reprocessing). The four main objectives of this study were to:

- develop estimates of the current inventories, projected generation rates, and characteristics of commerclal TRU wastes

- develop proposed acceptance requirements for TRU wastes forms and waste canisters that ensure a safe and effective disposal system

- develop certification procedures and processing requirements that ensure that TRU wastes delivered to a repository for disposal meet all applicable waste acceptance requi rements

- identify alternative conceptual strategies for treatment and certification of commercial TRU wastes.

The first objective was accomplished through a survey of commercial producers of TRU wastes. The survey included nuclear power plants, the west Valley Demonstration Project, former mixed-oxide fuel fabrication facilities that are planned to be decontaminated and decommissioned, future ory spent fuel rod consolidation facilities (at a Monitored Retrievable Storage (MRS) facility, if authorized, or at the repository), commercial research laboratories, and other industrial users of TRU isotopes. It was concluded that, assuming dry rod consolidation is implemented at the MRS facility or repository, the repository should be designed to receive and handle approximately $300 \mathrm{~m}^{3} / \mathrm{yr}$ of contact-handled TRU ( $\mathrm{CH}-\mathrm{TRU}$ ) wastes and $330 \mathrm{~m}^{3} / \mathrm{yr}$ of remote-handled TRU (RH-TRU) wastes (RH-TRU wastes are defined as those TRU wastes with surface dose 
rates greater than $200 \mathrm{~m} 117 \mathrm{irem} / \mathrm{hr}$ ). If dry rod consolidation is not implemented, these repository waste acceptance rates should be about 200 $\mathrm{m}^{3} / \mathrm{yr}$ for $\mathrm{CH}-$ TRU wastes and $60 \mathrm{~m}^{3} / \mathrm{yr}$ for RH-TRU wastes. These estimates do not include the non-fuel bearing components of spent-fuel assemblies that result from rod consolidation.

The TRU waste acceptance and certification requirements that were developed were based on regulatory requirements, information in the 1 iterature, and from similar requirements already established for disposal of defense TRU wastes in the Waste Isolation Pilot Plant (WIPP) which were adapted, where necessary, to disposal of commercial TRU wastes. Waste acceptance and certification requirements were proposed in the following technical areas:

$\begin{array}{ll}\text { Requirements for Waste Package } & \text { Requirements for Waste Form } \\ \text { Documentation (data package) } & \text { Thermal output } \\ \text { Labeling and color-coding } & \text { Nonradioactive hazardous materials } \\ \text { Maximum dimensions, weight } & \text { Pyrophoric materials } \\ \quad \text { and geometry } & \text { Organic materials } \\ \text { Handling features } & \text { Free liquids } \\ \text { Surface dose rate } & \text { Maximum temperature of waste form } \\ \text { Surface contamination } & \text { Canister/waste form compatibility } \\ \text { Canister durability } & \text { Leach resistance } \\ \text { Impact resistance } & \text { Immobilization } \\ \text { Fire resistance } & \text { Maximum pressure } \\ \text { Maximum temperature of canister } & \text { Volatility limit } \\ \text { Canister leak tightness } & \text { Gas generation } \\ \text { Quality assurance } & \text { Criticality safety }\end{array}$

The results of the TRU waste-producer survey indicated that there were a relatively large number of producers of small quantities of TRU wastes. It is not cost-effective for these sma11-quantity producers to construct and operate their own waste-treatment and certification facilities. Three conceptual strategies that were developed for providing these capabilities are briefly described below: 
1) waste producers provide these capabilities at their ow facilities

2) the DOE provides for use of existing or planned DOE facilities (including those to be used for treatment and certification of defense TRU wastes for disposal in the WIPP, the potential MRS Facility, or the repository)

3) a centralized commercial TRU waste facility is established.

Additional research is needed to determine the costs and feasibility of these concepts. 
'

$\checkmark$

$t$

$+$ 


\section{ACKNOWLEDGMENTS}

The authors wish to acknowledge the assistance provided by staff at PNL and the DOE Richland Operations Office. Special thanks go to Mr. W. A. Ross (PNL) and $M r . K$. J. Schneider (PNL) for their long hours of review and comment on the report, and particularly for reviewing section 4.0. Special thanks also go to Mr. D. C. Langstaff (DOE-RL) and Mr. B. M. Cole (PNL) for their efforts in coordinating and directing this work. The authors also wish to thank Ms. K. J Morgan, Ms. M. R. Guttenberg, and Ms. M. H. White for secretarial support and Mr. C. A. Counts for editing the report. 
a 


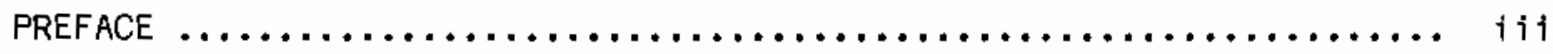

EXECUTIVE SUMMARY $\ldots \ldots \ldots \ldots \ldots \ldots \ldots \ldots \ldots \ldots \ldots \ldots \ldots \ldots \ldots \ldots \ldots \ldots$

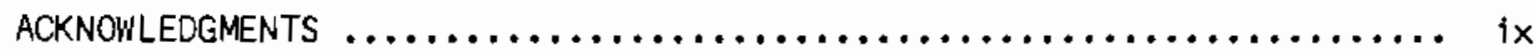

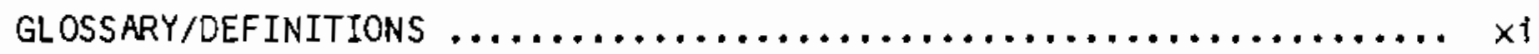

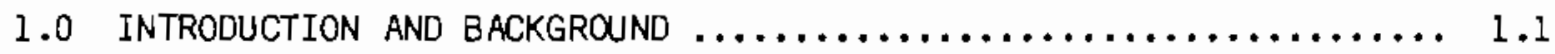

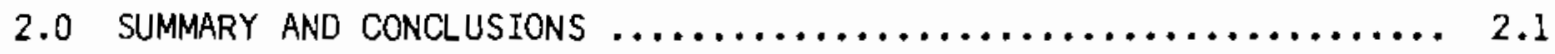

2.1 DESIGN BASIS FOR GEOLOGIC DISPOSAL OF COMMERCIAL

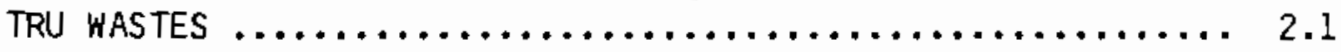

2.2 PROPOSED TRU WASTE ACCEPTANCE AND CERTIFICATION

REQUIREMENTS FOR REPOSITORY DISPOSAL $\ldots \ldots \ldots \ldots \ldots \ldots \ldots \ldots \ldots 2.7$

2.3 CONCEPTUAL TRU WASTE TREATMENT AND CERTIFICATION

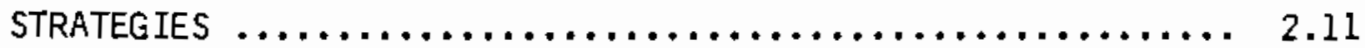

3.0 COMMERCIAL TRU WASTE INVENTORY AND CHARACTERISTICS $\ldots \ldots \ldots \ldots \ldots . . .1$

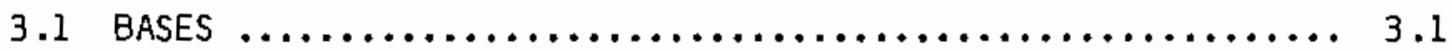

3.2 NUCLEAR FUel CYCle WASTES $\ldots \ldots \ldots \ldots \ldots \ldots \ldots \ldots \ldots \ldots \ldots \ldots \ldots \ldots .3$

3.2 .1 Nuclear Power Plants .................... 3.3

3.2.2 Fuel Reprocessing Facilities (West Valley Demonstration Project)..................... 3.8

3.2.3 Decontamination and Decommssioning of Former Mixed Oxide Fuel Fabrication Facilities ........... 3.10

3.2.4 Dry Spent Fuel Rod Consol idation Facilities ....... 3.14

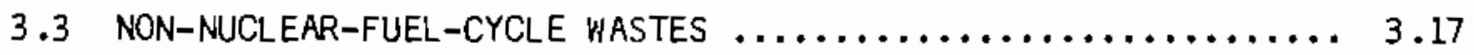

3.3.1 Commercial Research Laboratory Wastes............ 3... 37

3.3.2 Wastes From Other Industrial Users of TRU Isotopes ........................... 3.20

3.4 PLANNING BASE FOR GEOLOGIC DISPOSAL REQUIREMENTS $\ldots \ldots \ldots \ldots \ldots$

4.0 PROPOSED COMMERCIAL TRANSURANIC WASTE ACCEPTANCE AND CERTIFICATION REQUIREMENTS FOR DISPOSAL IN A GEOLOGIC REPOSITORY 


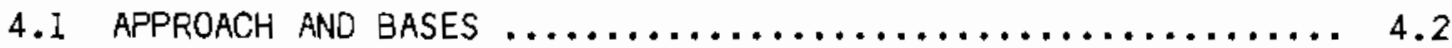

4.2 PROPOSED PACKAGED WASTE ACCEPTANCE REQUIREMENTS $\ldots \ldots \ldots \ldots \ldots .4 .7$

4.2 .1 Documentation........................... 4.7

4.2 .2 Labeling and Color Coding................... 4.10

4.2.3 Maximum Dimensions, Weight, Geometry............ 4.13

4.2 .4 Handing Features....................... 4.16

4.2 .5 Surface Dose Rate.......................... 4.18

4.2 .6 Surface Contamination..................... 4.21

4.2.7 Container Durabi7 ity, Leak Tightress, and
Compatability With Waste Form................ 4.23

4.2 .8 Impact Resistance...................... 4.26

4.2 .9 Fire Resistance............................. 4.29

4.2.10 Maximum Requirement of Waste Container........... 4.32

4.2 .11 Qual1ty Assurance.......................... 4.34

4.3 PROPOSED WASTE FORM ACCEPTANCE REQUIREMENTS $\ldots \ldots \ldots \ldots \ldots \ldots .4 .35$

4.3 .1 Thermat Output........................ 4.36

4.3.2 Nonradioactivo Hazardous Materials............... 4.39

4.3.3 Pyrophoric Materials....................... 4.40

4.3 .4 Organic Materials...................... 4.42

4.3 .5 Free Liquid............................ 4.45

4.3.6 Maximum Temperature of Waste Form............. 4.47

4.3 .7 Leach Resistance......................... 4.48

4.3 .8 Immobilization........................ 4.50

4.3.9 Maximum Pressure........................ 4.53

4.3 .10 Volati\}ity Limit........................ 4.55

4.3 .11 Gas Generation.......................... 4.56

4.3 .12 Criticality Safety...................... 4.59 
5.0 ALTERNATIVE TRU WASTE CERTIFICATION AND TREATMENT STRATEGIES $\ldots . .5 .1$

5.1 USE OF EXISTING OR PLANNED DOE FACILITIES $\ldots \ldots \ldots \ldots \ldots \ldots \ldots . . .1$

5.2 ESTABLISHMENT OF A CENTRALIZED COMMERCIAL WASTE

TREATMENT ANO CERTIFICATION FACILITY.............. 5.8

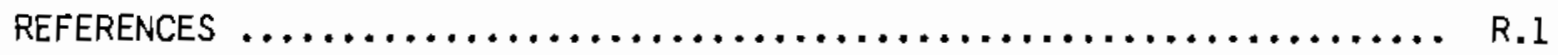

APPENDIX A RESULTS OF A SURVEY OF POTENTIAL PRODUCERS OF

TRANSURANIC WASTES $\ldots \ldots \ldots \ldots \ldots \ldots \ldots \ldots \ldots \ldots \ldots \ldots \ldots \ldots$. $I$

APPENDIX B A CONCEPTUAL WASTE CERTIFICATION PLAN $\ldots \ldots \ldots \ldots \ldots \ldots \ldots$ B.

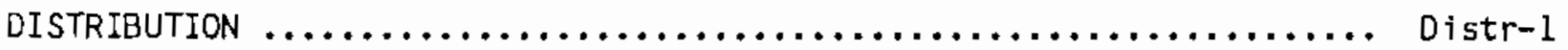


,

-. 


\section{EIGURES}

1.1. Diagram of Once-Through Nuciear Fuel Cycle $\ldots \ldots \ldots \ldots \ldots \ldots \ldots . . . . .3$

2.1 Summary of Proposed TRU Waste Acceptance Requirements for Repository Disposal............................ 2.9

4.1 Illustration of Approach to Develop TRU Waste Acceptance Requirements................................... 4.3

4.2 Purpose of Each TRU Waste Acceptance Requi rement............ 4.4

5.1 Illustration of Four Aiternative TRU Waste Treatment and Certification Strategies.......................... 5.2

B.1 Waste Form Check List........................... 8.5

B.2 Waste Package Data Sheet......................... 8.6

B.3 Organization Chart of ORNL Quality Assurance Program......... B.11 


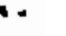




\section{IABLES}

2.1 Summary of TRU Waste Survey Results (Best Estimate)......... 2.3

2.2 Summary of $\mathrm{RH}-$ and $\mathrm{CH}-$ TRU Waste Quantities, Numbers of Waste Containers.................................... 2.5

3.1 TRU waste Volumes Resulting From TMI Cleanup.............. 3.5

3.2 Treated Waste Quantities From TMI Cleanup................ 3.6

3.3 Estimated RH and CH-TRU Waste Generation Rates from the Potential MRS Facility.............................. 3.16

3.4 Repository Design Basis for Transuranic Wastes............. 3.27

3.5 Summary of RH- and $\mathrm{CH}-$ TRU Waste Quantities, Numbers of Waste Contalners...................................... 3.33

A.1 Summary of TRU Waste Quantities Generated at Commercial Nuclear Power Plants.................................... A.2

A.2 Summary of TRU Waste Quantities Generated by the West Valley

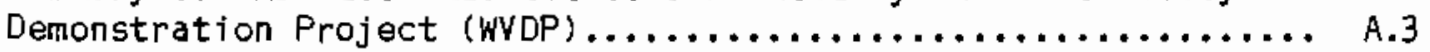

A.3 Summary of TRU Waste Quantities Generated During Decontamination and Decommissioning of Mixed Oxide Fuel Fabrication Facilities.. A.4

A.4 Summary of TRU Waste Quantities at Commercial Laboratories...... A.5

A.5 Summary of TRU Wastes From Other Industrial Users of TRU I sotopes..................................... A.6

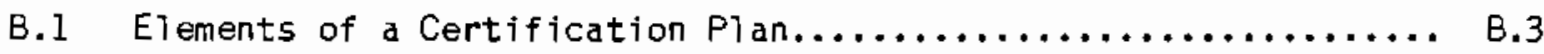


$\ddots$
$\cdots$

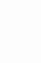




\section{GLOSSARY/OEFINIIIONS}

BW IP

Container

$\mathrm{CH}-\mathrm{TRU}$ Waste

Corrosive

Materials

Spent Fuei

Consolidation

Defense Waste

Engineered

Barriers

Free Liquids

HEPA Fi1ters

Immobilized

Materials

Lithostatic

Pressure

MRS Facility

Nanocuries

NNHSI

ONHI
Basalt Waste Isolation Project

Refers to overpack container placed around a waste container

Contact-handled TRU waste; TRU waste materials that are packaged such that the dose rate at the surface of the waste canister is less than $200 \mathrm{millirem} / \mathrm{hr}$

Materials defined as such in 49 CFR 173

The operation performed on spent fuel assemblies during which the upper and lower tie-plates are removed, the assembly spacer grids and other structural components are removed, and the fuel rods are collected and placed into a canister in a close-packed configuration

Radioactive wastes derived from atomic energy defense activities

The man-made components of the disposat system designed to prevent the release of radionuclides from the underground facility into the geohydrologic setting. These include the waste form, primary canister, materials placed over and around the canister, any other components of the waste package, and barriers used to seal penetrations in and to the undergound facility

Liquid that is not sorbed into a host materfal such that it could spill or drain from its container

High efficiency particulate air filters

Materials that are fixed in a matrix such as glass, ceramic, cement, etc.

The confining pressure at depth in the crust of the earth caused by the weight of the overlying rocks

Monitored Retrievable Storage Facility

A unit of radioactivity; (nanocurie $(n \mathrm{C} i)=10^{-9} \mathrm{C}$ i

Nevada Nuclear Waste Storage Investigations Project

Office of Nuclear Waste Isolation 


\begin{tabular}{|c|c|}
\hline Overpack & $\begin{array}{l}\text { An overpack is a second container placed around the waste } \\
\text { canister to provide additional structural and corrosion } \\
\text { protection for the contained TRU wastes }\end{array}$ \\
\hline $\begin{array}{l}\text { Pyrophoric } \\
\text { Materials }\end{array}$ & $\begin{array}{l}\text { Materials that might ignite spontaneously under ambient } \\
\text { conditions. A comprehensive listing of these materials } \\
\text { is found in } 49 \text { CFR } 173\end{array}$ \\
\hline Radiolysis & $\begin{array}{l}\text { Decomposition or splitting of a molecule (often the water } \\
\text { molecule) due to effects of radiation }\end{array}$ \\
\hline SNF & Spent Nuclear FueT \\
\hline $\begin{array}{l}\text { Transuranic } \\
\text { (TRU Waste) }\end{array}$ & $\begin{array}{l}\text { Radioactive wastes contaminated with certain alpha-emitting } \\
\text { radionuclides of atomic number greater than } 92 \text { and half- } 1 \text { ives } \\
\text { greater than } 20 \text { years in concentrations greater than } 100 \text { nand } \\
\text { curies per gram, as implemented by } 40 \text { CFR } 191\end{array}$ \\
\hline RH-TRU Waste & $\begin{array}{l}\text { Remote-handled TRU waste; TRU waste materials packaged such } \\
\text { that the dose rate at the surface of the waste canister is } \\
\text { greater than } 200-m i l l i \text { rem/hr }\end{array}$ \\
\hline $\begin{array}{l}\text { Waste } \\
\text { Canister }\end{array}$ & $\begin{array}{l}\text { The primary or innermost container for TRU wastes. Examples } \\
\text { include various sizes of steel boxes, drums, and cylindrical } \\
\text { canisters. }\end{array}$ \\
\hline Waste Package & $\begin{array}{l}\text { The system of engineered components immediately surrounding } \\
\text { an individual waste container that may include waste form, } \\
\text { stabilizer, canister, overpack, sleeve, and backfill } \\
\text { material }\end{array}$ \\
\hline WIPP & Waste Isolation Pilot Plant \\
\hline NIPP-WAC & ceptance Criteria \\
\hline
\end{tabular}




\subsection{INTROOUCIION AND BACKGROUND}

The Nuclear Waste Policy Act of 1982 (NWPA) provides for the ultimate disposal of commercially generated radioactive wastes in a deep geologic repository. The radioactive wastes for disposal include spent nuclear fuel, high-level wastes (HLW) from reprocessing of spent fuel, and other highiy radioactive materials that the U.S. Nuclear Regulatory Commission (NRC) determines by rule requires permanent isolation. A7though the NRC has not yet promulgated such a rule, it is presumed here as a basis for this study that transuranic (TRU) wastes will require repository disposal. Transuranic wastes are defined as wastes that contain more than 100 nanocuries $(n C i)$ of alpha-emitting transuranic isotopes with half-lives greater than twenty years per gram of waste. Examples of TRu isotopes include $\mathrm{Np}-237, \mathrm{Pu}-238, \mathrm{Pu}-239$, $\mathrm{Pu}-240, \mathrm{Pu}-242, \mathrm{Am}-241, \mathrm{Am}-243, \mathrm{Cm}_{\mathrm{m}} 245$, and $\mathrm{Cm}_{\mathrm{r}} 246$. These isotopes are generated in nuclear reactors during irradiation of uranium fuel. These isotopes typically remain within the uranium dioxide fuel pellets until the fuel is reprocessed. If the irradiated (or spent) fuel is not reprocessed, spent fuel will be disposed of in a reposftory and most of the TRU isotopes will remain in the spent fuel. However, small quantities of TRU wastes will still be generated. There are principally two types of TRU wastes; 1) contact-handled $(\mathrm{CH})$, which are those packaged TRU wastes that have a radiation dose rate at the surface of the waste container that is less than $200 \mathrm{mili} i \mathrm{rem} / \mathrm{hr}$, and 2) remote-handled $(R H)$, which have surface dose rates greater than $200 \mathrm{mili} \mathrm{irem} / \mathrm{hr}$.

Geologic repository programs initially focused on disposal of spent fuel reprocessing wastes (HLW and TRU wastes). However, commercial spent fuel reprocessing is not considered a viable business in the near term. Therefore, it is not anticipated that TRU wastes generated during fuel reprocessing (and subsequent mixed oxtde fuel fabrication) operations will be disposed of in the first commercial repository. The Department of Energy (DOE) is currently planning to dispose of spent fuel in the first repository (i.e., the once- 
through fuel cycle is assumed.) Vitrified HLW from DOE defense prograns and from the Hest Valley Demonstration Froject will also be disposed of in the first repository. A diagran of the nuclear fuel cycle without reprocessing is shown in Figure 1.1. As shown, the emphasis has shifted to disposal of commercial spent nuclear fluel and TRU wastes from sources other than reprocessing facilities.

This report focuses on TRU wastes generated without fuei reprocessing. A companion report(a) focuses on disposal of non-fuel bearing components of spent fuel assemblies. The objectives of this study are:

1) to develop a detaiied assessment of the sources, quantities, and characteristics of existing and future commercial TRU wastes

2) to develop proposed acceptance requirements for TRU waste forms and packaged TRU wastes that ensure safe and effective disposal in a geologic repository

3) to develop certification procedures and processing requirements that ensure wastes meet proposed acceptance requirements

4) to identify alternative conceptual strategies for providing treatment and certification of commercial TRU wastes.

In 1983, Hazelton(b) performed a preliminary survey to identify commerciat nuclear facility operators that ow TRU wastes and to determine their inventories and projected waste generation rates, waste forms, and handing requirements. The Hazelton(a) survey was used as a starting point to obtain additional information, such as physical and radiochemical characteristics of the waste forms. This information was updated for this PNL study.

(a) Luksic, A. T., et a?. 1985. "Repository Disposal Requirements for Spent FueT Disassembly Hardware and Other Non-Fuel Components, "Draft to be publ ished, Pacific Northwest Laboratory, Richl and, Washington.

(b) Hazelton, R. F. 1983. "Commercial Transuranic Haste Inventory Survey" Letter Report. Pacific Northwest Laboratory, Richland, Washington. 


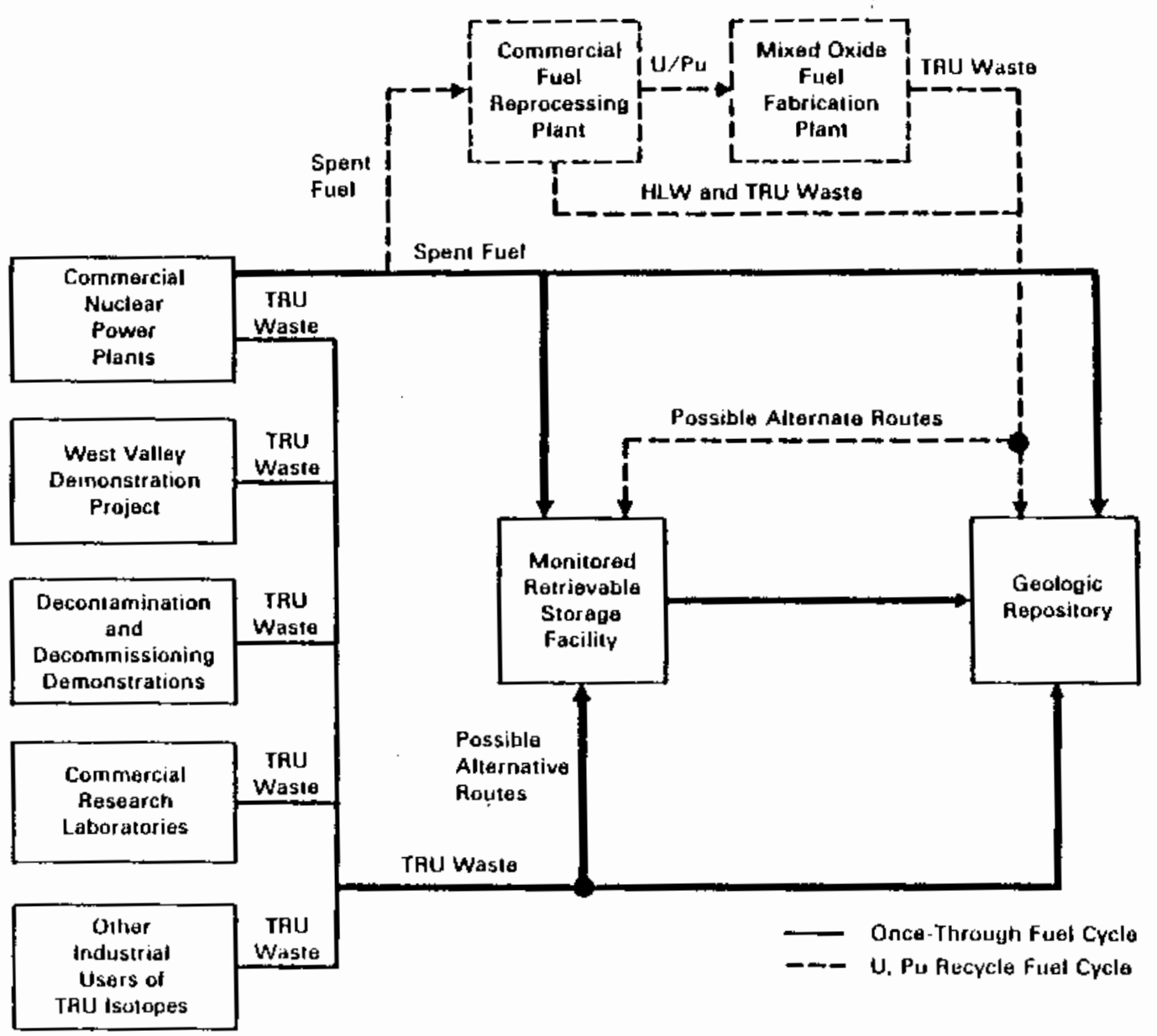

FIGURE 1.1. Diagram of Commercial Nuclear Fuel Cycle Waste Streams 
Currently there are no specific provisions for disposal of some of the currently generated TRU wastes. These wastes are generated by commercial fims that do not generate electricity. TRU isotopes are used for purposes such as well-logging, sensors in snoke detectors, and other applications and in research applications employing sealed sources or small quantities of radioisotopes. Since these users are not generating electricity, they are not paying for the civitian repository program (which is based on a fee of $1 \mathrm{mill} / \mathrm{kwh}$ of nuclear-generated electricity). Acceptance of these wastes for disposal is not addressed under provisions of the NWPA. However, because these wastes contain TRU isotopes in concentrations that exceed shallow-land burial limits, they are not acceptable at commercial low-level waste (LLW) disposal facilities and their disposal may ultimately be in a commercial repository. Thus, they are considered as materials for geologic disposal in this study.

Commercial nuclear power reactors are also a potential source of TRU wastes. However, the TRU isotopes are normally contained within the fuel pellets and would not be released in large quantities unless there were significant fuel failures. In addition to TRU wastes, commerciai reactors may generate wastes that are not necessarily classified as TRU but that exceed the Class $C$ low-level waste 1 imits and are thus not acceptable at a shallow-land burial ground (unless the NRC approves their disposal on a case-by-case basis).

Other TRU wastes for civilian repository disposal addressed in this report include DOE-owned wastes that were not generated in defense-program-related activities. TRU wastes produced in defense program activities are scheduled for disposal in the Waste Isolation Pilot Plant (WIPP) repository. However, there is some uncertainty regarding the disposition of the DOE-owned wastes generated by non-defense-related activities (e.g., research programs supporting the commercial nuclear industry).

This report al so proposes acceptance requirements for TRU wastes to be disposed of in a commercial repository. These requirements estab1 ish the

(a) Hazelton. 1983. See page 1.2. 
a] lowable properties of TRU waste forms and waste packages that are considered necessary for protecting the health and safety of the repository operators and the general pubific. Protection of the general public from the radiation contained within a repository is provided by a system of engineered barriers (e.g., waste forms, waste containers, overpack containers, and backfil materials) and the geologic media. It is assumed that the final waste package assembly operations, including placing the primary waste containers into any required overpack containers and installing the backfill material (if any), wili be performed at the repository. Therefore, waste acceptance requirements are assumed to appiy to only the waste form and the primary waste container (i.e., the configuration in which wastes will be delivered to the repository). The proposed requirements presented in this report represent the first stage in acceptance requirement development. It is expected that these requirements will be revised as additional information regarding repository geotechnical parameters, repository designs, and waste package designs are developed.

The third objective of this study is to develop commerciai TRU waste certification requirements, that is, methods that coulo be used by waste producers to ensure that their wastes are prepared in accordance with the waste acceptance requirements. Certification requirements can be administrative controls, tests, analyses, and procedures that would be used by waste producers to provide evidence to DOE that the wastes sent to a repository meet all applicable waste acceptance requirements. Because of the precedent of requirements placed on waste generators shipping to WIPP, it is assumed that waste producers will be required to perform a detailed evaluation of wastes intended for disposal in a repository, including assessments of the chemical, physical, and radiological characteristics of the wastes. This information would form the basis for a waste certification plan that would indicate how each producer intends to demonstrate or verify that their wastes meet the acceptance requirements for repository disposal.

The final objective of this report is to develop al ternative conceptual strategies for producers of TRU wastes to use in treating and certifying their 
wastes for repository disposal. Hazelton(a) determined that there were a relatively iarge number of producers of small quantities of TRU wastes. In most. cases, it would not be cost-effective for these producers to build their own treatment and certification facilities. As a result, some provisions will be needed in the future for treating and certifying the TRU wastes that will be generated by small-quantity producers.

The rest of this report is divided into four main sections and two appendices. Section 2.0 presents a summary of the results of this study and the conclusions drawn from these results; Section 3.0 describes the results of the survey of producers of TRU wastes and presents the design basis for a repository to dispose of these wastes; Section 4.0 presents proposed waste acceptance and certification requirements established for disposa? of these wastes in a geologic repository; and Section 5.0 presents alternative waste treatment and certification strategies that could potentially be used to prepare these wastes for repository disposa1. Detailed TRU waste inventories and generation rates are presented in Appendix $A$ and Appendix B describes a waste certification plan and waste certification qual ity assurance requirements that coulo be used by waste producers to provide evidence to DOE that the wastes they plan to dispose of in a repository meet the applicable waste acceptance requirements.

(a) Hazelton. 1983. See page 1.2. 


\subsection{SUMMARY AND CONCLUSIONS}

The U.S. Department of Energy's (DOE's) Office of Civilian Radioactive Waste Management (OCRWM) is developing a system to be used for the geologic disposal of commercially generated radioactive wastes. The principal types of radioactive wastes that require disposal include spent nuclear fuel rods, the non-fuel-bearing components of spent-fuel assemblies, defense high-level wastes (DHLW), Hest Valley high-level wastes (WVHLW), and presubiatly transuranic (TRU) wastes. This report focuses on the requirements for disposai of conimercial TRU wastes that are generated without fuel reprocessing. The four main objectives of this study were:

1) to develop estimates of the current inventory, projected generation rates, and characteristics of commercial TRU wastes (this information will contribute to the design basis for repository facilities)

2) to deveicp proposed acceptance requirements for TRU waste forms and waste containers that ensure a safe and effective disposal system

3) to develop certification procedures and processing requirements that ensure that TRU wastes meet all applicable waste acceptence requirements

4) to identify alternative conceptuai strategies for treatment and certification of commercia? TRU wastes.

The results and conclusions from this study are discussed in the following subsections.

\subsection{DESIGN BASIS FOR GEOLOGIC DISPOSAL OE COMMERCIAL TRU WASTES}

The results of a survey that was performed to estimate the quantities and characteristics of existing and future commercial TRU wastes are suramarizec in this section. This study aiso presents estimates of the quantities of low-ievel vastes (LLW) that are contaminated with radionuclides in concentrations greater 
than the $\mathrm{Class} C \mathrm{C}$ imits that are acceptable for shallow-land burial. This information is needed to establish a design basis for waste receiving, handing, storage and disposal systems at federal monitored retrievable storage (MRS) facilities and repository facilities. In the past, emphasis was placed on TRU wastes from commercial reprocessing facilities. However, since commercial reprocessing of spent nuclear fuel is not now anticipated for many years, emphasis has shifted to nonreprocessing wastes. For this reason, this study examines commercial TRU wastes that are generated from activities other than reprocessing of commercial spent fuel.

The final disposition of much of the TRU wastes examined in this study is uncertain. Some of the TRU wastes that are generated by commercial activities are being offered to DOE in exchange for research results. These wastes may ultimately become DOE-owned even though they were generated at commercial nuciear facilities. If a11 DOE TRU wastes are found to be acceptable for disposal at WIPP, some of the TRU wastes examined in this study may be disposed of at WIPP. Otherwise, these wastes could be candidates for a civilian waste repository. A second uncertainty involves commercial producers of TRU wastes that are not involved in the generation of electricity (i.e., they are not paying the $1 \mathrm{mill} / \mathrm{kW}-\mathrm{hr}$ foe for nuclear waste disposal that was set up by the NWPA). A special payment provision may have to be set up for these organizations to reimburse the Nuclear Waste Fund. A final uncertainty involves the greater-than-Class-C LLW. These wastes may ultimately be acceptable on a case-by-case basis for shallow-land burial or may eventually require repository disposal.

Nonreprocessing TRU wastes may be generated at commercial nuclear power plants, research laboratories, industrial facilities that fabricate RUisotope-using equiprent, and from decontamination and decommissioning (D\&D) of commercial facilities that were previously contaminated with TRU isotopes. An example of the latter is the West Valley Demonstration Project. The results of the TRU waste survey are sumarized in Table 2.1. The split between $\mathrm{RH}-\mathrm{TRU}$ and 
IABLE 2.1. Summary of TRU Waste Survey Results (Best Estimate)

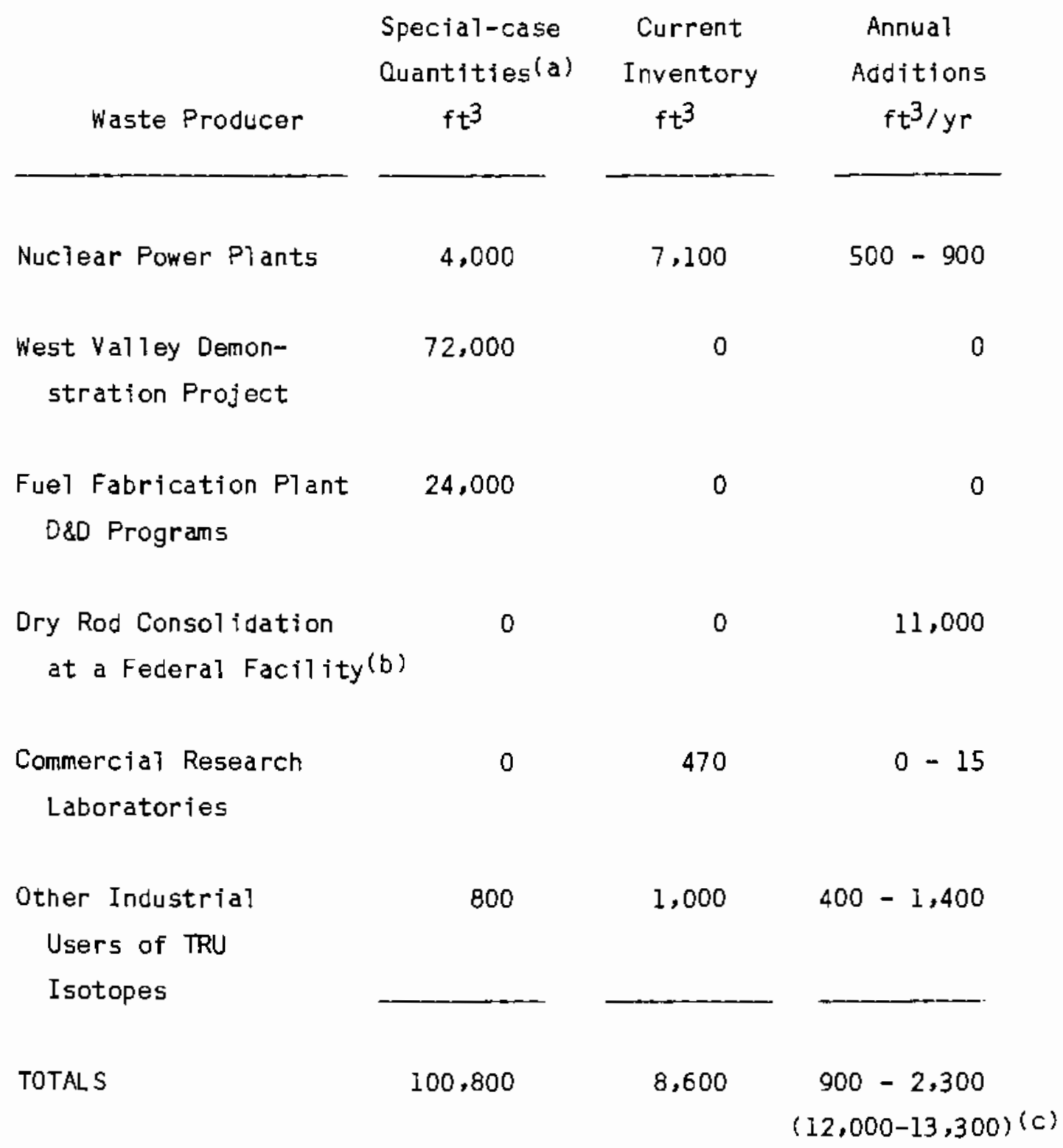

(a) Special-case quantities are those TRU wastes that have been or wi11 be produced on a one-time basis.

(b) Waste generation rate assuming spent fuel is consolidated at a rate of 3,000 MTU/yr. These wastes coulo be generated at the potential MRS facil ity or at the repository.

(c) Total annual generation rate assuming at-MRS or at-repository consolidation is implemented. 
Ch-TRU wastes is shown in Table 2.2, as well as the estimated number of waste containers. The waste volumes shown in the tables are the best available estimates. Actual TRU waste volumes may be as much as a factor of two higher, except for the potential MRS facility wastes generation estimates which include some wastes that may ultimately be classified as LLW. A more comprehensive survey, including visits to actual sites, would be required to reduce this uncertainty.

To estimate an average TRU waste receipt rate for the repository jesign, basis, which includes rod consolidation, the waste volumes and generation rates in Tabie 2.1 were extrapolated to the year 2022 (the last year under current pianning that the first repository will receive wastes for disposal; DOE 1985). It was assumed here that the repository receipt rate will be based on disposing of all of the current inventory, special-case quantities, and newly generated TRU wastes over a 20 - year period. It was estimated that the total inventory cf $\mathrm{CH}-\mathrm{TRU}$ wastes through the year $2022 \mathrm{will}$ be about $210,000 \mathrm{ft}^{3}\left(6,000 \mathrm{~m}^{3}\right)$ and the inventory of RH-TRU waste w111 be about $230,000 \mathrm{ft}^{3}\left(6,500 \mathrm{~m}^{3}\right)$. To dispose of these wastes over a $20-y r$ period, the repository would have to be designed to receive about $10,500 \mathrm{ft} 3 / \mathrm{yr}\left(300 \mathrm{~m}^{3} / \mathrm{yr}\right)$ of $\mathrm{CH}$-TRU waste and about $11,500 \mathrm{ft} 3 / \mathrm{yr}\left(330 \mathrm{~m}^{3} / \mathrm{yr}\right)$ of RH-TRU wastes. In terms of waste containers, these receipt rates correspond to approximateiy 1,500 55-gal orumis per year of $\mathrm{CH}-\mathrm{TRU}$ waste and about $400 \mathrm{RH}-\mathrm{TRU}$ waste containers/yr (assurning the RH-TRU waste container holds four 55-gal druns).

Assuming dry rod consolidation is not implemented, about 70 percent of the TRU wastes included in this survey will result from the West Valley Demonstration Project and an additional 20 percent will result from D\&D Programs at four commercial fuel fabrication facilities. The remaining 10 percent is spread over about 40 facilities that were contacted during this survey. Thus, with the exception of the five facilities mentioned above, nost commercial organizations that own TRU wastes do not have large quantities. 
Table 2.2. Summary of $\mathrm{RH}-$ and $\mathrm{CH}-\mathrm{TRU}$ Waste Quantities, Numbers of Waste Containers ( $\mathrm{ft}$ )

Special Quantities Current Inventory Annual Additions

Waste Producer $\mathrm{CH}-\mathrm{TRU}$ RH-TRU CH-TRU RH-TRU CH-TRU RH-TRU

\begin{tabular}{|c|c|c|c|c|c|c|}
\hline Nuclear Power Plants & $\begin{array}{c}520 \\
(3,600)\end{array}$ & $\begin{array}{c}15 \\
(400)\end{array}$ & $\begin{array}{c}910 \\
(6,400)\end{array}$ & $\begin{array}{c}25 \\
(700)\end{array}$ & $\begin{array}{c}65-120 \\
(450-840)\end{array}$ & $\begin{array}{c}2-4 \\
(50-100)\end{array}$ \\
\hline $\begin{array}{l}\text { West Valley Demonstration } \\
\text { Project }\end{array}$ & $\begin{array}{c}5,150 \\
(36,000)\end{array}$ & $\begin{array}{c}1,300 \\
(36,000)\end{array}$ & -- & -- & -- & -- \\
\hline $\begin{array}{l}\text { Fuel Fabrication Plant } \\
\text { D \& D Programs }\end{array}$ & $\begin{array}{c}3,430 \\
(24,000)\end{array}$ & --- & -- & -- & -- & -- \\
\hline $\begin{array}{l}\text { Dry Rod Consol idation } \\
\text { Facility }\end{array}$ & $-\infty$ & -- & -- & -- & $\begin{array}{c}440^{*} \\
(3,100) *\end{array}$ & $\begin{array}{c}290^{*} \\
(8,100)^{*}\end{array}$ \\
\hline $\begin{array}{l}\text { Commercial Research } \\
\text { Laboratories }\end{array}$ & $-\infty$ & -- & $-\infty$ & $\begin{array}{c}20 \\
(470)\end{array}$ & -- & $\frac{1}{(30)}$ \\
\hline $\begin{array}{l}\text { Other Industrial Users } \\
\text { of TRU Isotopes }\end{array}$ & $\begin{array}{l}120 \\
(800)\end{array}$ & $-\infty$ & $\begin{array}{c}150 \\
(1,000)\end{array}$ & --- & $\begin{array}{c}60-200 \\
(420-1,400)\end{array}$ & -- \\
\hline \multirow[t]{2}{*}{ TOTALS } & $\begin{array}{c}9,220 \\
(64,400)\end{array}$ & $\begin{array}{c}1,320 \\
(36,400)\end{array}$ & $\begin{array}{l}1,060 \\
(7,400)\end{array}$ & $\begin{array}{c}45 \\
(1,200)\end{array}$ & $\begin{array}{l}130-320 \\
(900-2,200)\end{array}$ & $\begin{array}{c}2-4 \\
(80-130)\end{array}$ \\
\hline & & & & & $\begin{array}{c}570-760^{*} \\
000-5,300)^{*}\end{array}$ & $\begin{array}{c}300^{*} \\
(8,200) *\end{array}$ \\
\hline
\end{tabular}

(a) CH-TRU Waste quantities are given in units of 55-gal drum-equivalents. Conversion factor: $1 \mathrm{ft}=0.028 \mathrm{~m}$.

(b) RH-TRU waste quantities are given in units of RH-TRU waste-container-equivalents. The RH-TRU waste container is assumed to hold four 55-gal drums.

(c) Numbers followed by an asterisk (*) indicate the annual TRU waste generation rate if atm MRS or at-repository consolidation is implemented. 
If dry rod consolication is not implemented, the total amount of TRU wastes and greater-than-Class-C LLW that will be available for disposal through 2025 wili be approximately $180,000 \mathrm{ft}^{3}\left(5,100 \mathrm{~m}^{3}\right)$. Approximately 80 percent, or $140,000 \mathrm{ft}^{3}\left(4,000 \mathrm{~m}^{3}\right)$, is estimated to be contact-handled TRU waste and the remaining 20 percent, or approximately $40,000 \mathrm{ft}^{3}\left(1,100 \mathrm{~m}^{3}\right)$, is estimated to be remote-handled TRU waste. To dispose of these wastes over a 20-yr. pertod, the reposttory would have to be designed to receive about 7,000 $\mathrm{ft}^{3} / \mathrm{yr}\left(200 \mathrm{~m}^{3} / \mathrm{yr}\right.$.) of $\mathrm{CH}-\mathrm{TRU}$ wastes and $2,000 \mathrm{ft}^{3} / \mathrm{yr}^{2}\left(60 \mathrm{~m}^{3} / \mathrm{yr}\right)$ of RH-TRU wastes.

Throughout the survey, it was evident that most organizations are uncertain about the actual quantities and characteristics of their TRU wastes. Littie or no treatment has been applied to the wastes. As a result, a wide variety of waste forms and properties must be consicered. Current TRU wastes consist of nonhomogeneous trash and debris that are contaminated with TRU isotopes. Most organizations do not know the level of TRU contamination in their wastes so they are uncertain in many cases whether or not the wastes should even be classified as TRU. The primary reason for this uncertainty is the high cost of installing and operating a waste assay facility that could adequately characterize the TRU isotope content of the wastes. It is not cost-effective for the many organizations with small quantities of TRU wastes to install such a facility.

A similar conclusion was drawn regarding the cost-effectiveness of waste treatment facilities. The survey indicated that treatment of most TRU wastes has been minimal. According to NRC regulations, liquid wastes must be solidified prior to shallow land disposal (10 CFR 61) and repository cisposal (10 CFR 60). TRU waste acceptance criteria for the WIPP also includes this requirement. Thus, it is anticipated that similar requirements will be imposed on TRU-contaminated 1 iquid wastes. In addition, it will be shown later that untreated organic materials will not be acceptable for repository disposal. Several treatment options are available for organic materials, inciuding incineration/cenentation and shredding/cementation. Thus, cemented wastes are 
expected to be a relatively common TRU waste form. Solid wastes are already in a relatively stable form and, as a result, have received less treatment. Only the West Valley Demonstration Project and the MRS Program indicated they would compact their compactable TRU wastes.

In general, the survey indicated that paper, plastic, and glass wastes in the past were essentially packaged without treatment and metallic wastes received minimal treatment (e.g., cutting and sectioning, spraying with a fixative agent, or placing them in plastic bags prior to their placement in larger metal waste containers). These practices have cominated TRU waste treatment and packaging activities in the past and are expected to continue to a large extent in the future.

It was conciuded that the reference TRU waste forms for repository design bases will include liquid wastes that have been evaporated or dewatered and incorporated into a cement matrix. The reference form for organic and combustible materials will be cement, either with shredded or incinerated organics within it. Metallic wastes will be essentially untreated with the exception of potential sizing or spraying operations. These wastes will generally receive no treatment to reduce volumes or alter the waste form prior to repository disposal. The reference waste container should be the DOT $17 \mathrm{H}$ 55-gal steel drum, al though the repository design should include provisions for receiving 1 arger waste containers, such as various sizes of drums and metal boxes. The larger boxes are needed for packaging of large itens, such as contaminated failed equipment.

\subsection{PROPOSED TRU WASTE ACCEPTANCE AND CERTIFICATION REQUIREMENTS FOR REPOSITORY DISPOSAL}

A team was established to develop proposed requirements related to the acceptance of TRU waste forms and waste containers at a repository. The team consisted of three members. One member was assigned to represent the interests 
of waste producers, another member represented the potentiai MRS facility, and the third member represented the repository. Transportation concerns were considered by all three members. The team was organized in that way to ensure that the concerns and considerations of all four major parts of the waste management system were addressed. Part of the effort to develop proposed TRU waste acceptance requirements was sponsored by the DOE Office of Nuclear Energy (NE) through the commercial Nuclear Waste Treatment Program at PNL. The team a) so developed proposed waste certification requirements to which waste producers must comply to certify to DOE that their wastes meet all applicable acceptance requirements for repository disposal. It was assumed that each waste producer will be required to submit a waste certification plan for DOE approval (see Appendix B) that describes the tests, analyses, controls, and processing techniques that will be used to provide evidence that the wastes meet the acceptance requirements.

The proposed waste acceptance and certification requirements were developed primarily from information in the literature and from federal regulations. The principal sources of information were reports prepared to support acceptance and certification of defense-program-related TRU wastes for disposal in the WIPP. Haste acceptance requirements developed for commercial high-level wastes for disposal at repositories in all three potential geologic media (salt, basalt, and tuff) were also utilized. These requirements were adapted, where necessary, to acceptance requirements for TRU wastes. The federal reguiatory requirements that were used include regulations promulgated by the NRC, the Department of Transportation (DOT), and the Environmental Protection Agency (EPA). A list of applicable regulations is presented in Section 4.0 .

The proposed TRU waste acceptance requirements are summarized in Figure 2.1. These requirements are described in more detail in Section 4.0. Some of the major implications of these requirements and implications of the proposed certification requirements are as follows: 


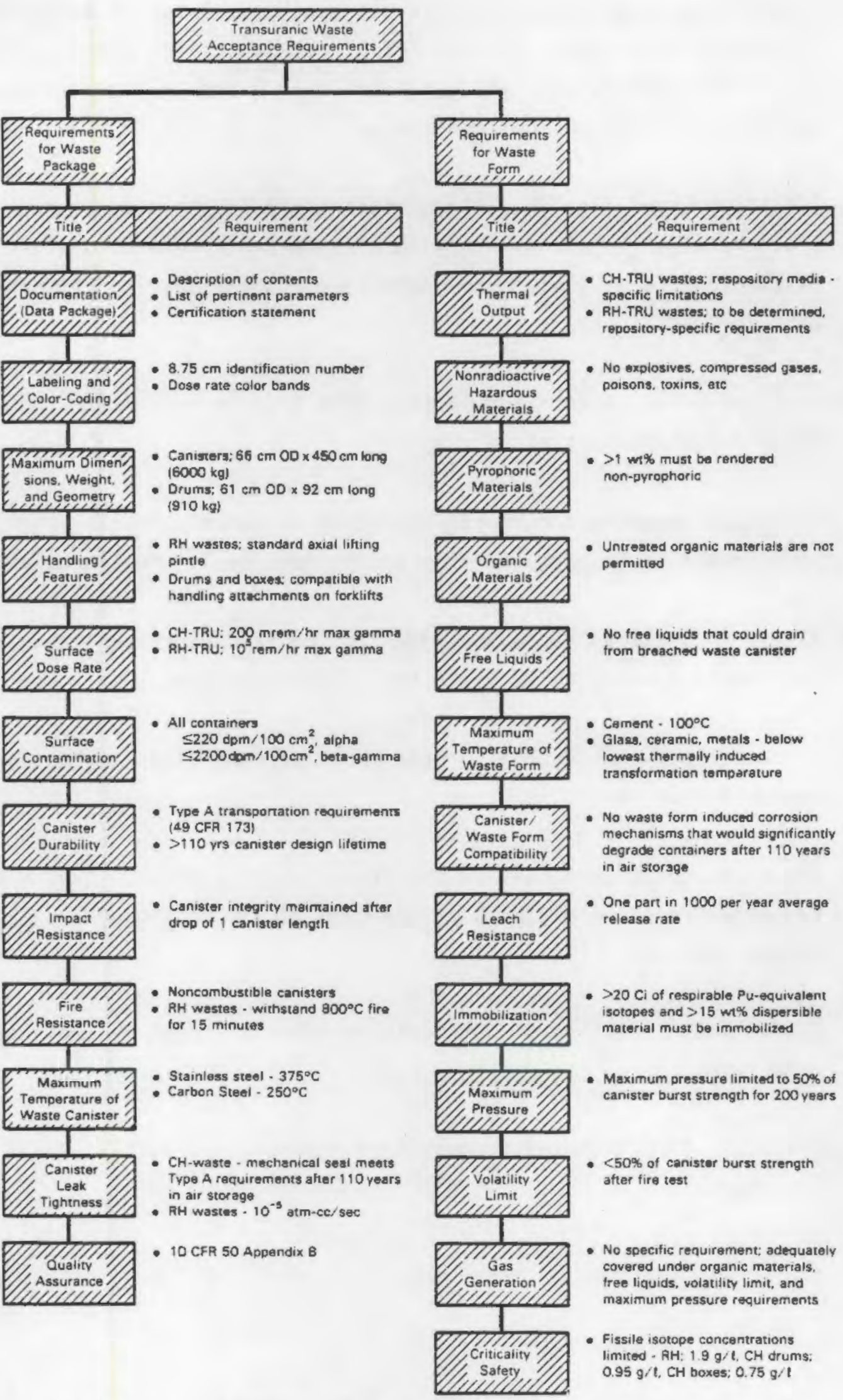

FIGURE 2.1. Summary of Proposed TRU Waste Acceptance Requirements for Repository Disposal 
- Organic and other combustible wastes must be treated to render them noncombustible. Thus, it will not be acceptable for waste producers to simply load paper, plastic, cardboard, etc., into waste containers and ship them off to the repository.

- A filtered vent for TRU waste containers is recommended to reduce problems with gas generation within waste containers during storage or disposal. The vent would be mechanically sealed during transportation and handling operations.

- Finely-divided powders and particulates must be immobilized in cement or other suitable material.

- All waste containers must be fabricated of noncombustible materials to prevent the waste packages from adding fuel to a potential fire.

- All waste packages to be delivered to the repository must receive a radionuclide assay to estimate the isotopic content.

- Al1 waste packages must also have their surface dose rate and surface contamination levels measured.

- TRU waste containers must be capable of meeting the DOT Type A shipping container requirements both at the time of production and after 110 years in air storage.

- CH-TRU waste containers must be color-coded to identify their surface dose rates.

- TRU waste form leach rates must be 1 imited to one part in one thousand per year. 
- Waste producers, and the repository operators must implenient a quality assurance plan that is consistent with the requirements of 10 CFR 50, Appendix B.

\subsection{CONCEPTUAL TRU WASTE TREATMENT AND_CERTIFICATION STRATEGIES}

The results of the commercial IRU waste survey indicated that there are a relatively large number of producers of small quantities of commercial TRU wastes. It is not cost-effective for these waste generators to construct and operate their own waste treatment and certification facilities. As a result, three conceptual strategies for providing these capabilities for small-quantity producers were developed. The first, as mentioned above, is for waste producers to provide these capabilities themselves. The other two strategies are briefly described below:

Use of Existing or Planned DOE Facilities: Federal nuclear sites, such as the Idaho National Engineering Laboratory (INEL), Hanford, Oak Ridge National Laboratory (ORNL), and Rocky Flats Plant (RFP), are currently preparing to dispose of their defense IRU wastes at WIPP. Many of the Federal sites are developing waste treatment and certification facility concepts for this purpose. Some of the DOE facilities that could potentialiy be used are described in this report. These DOE facilities have capabilities such as incineration/ immobitization, passive and active neutron interrogation, gamma radiography, and $x$-ray real-time radiography. It may be possible for producers of small quantities of commercial IRU wastes to use these facilities to treat and certify their wastes for disposal in a commercial repository. This concept should be explored further.

Estab]ish a Centralized Commercjal_TRU Waste Eacility: The third potential concept is to establish a centralized TRU waste treatment and certification facility that could be used by all of the small-quantity producers. In this concept, the centralized facility would be provided with all of the capabilities necessary to produce a waste package that meets the acceptance requirements. 
Waste producers would be required to prepare thef $r$ wastes in accorance with applicable transportation regulations but wculo not necessarily be required to meet the acceptance requirements for repository disposal. The treatment and certification capabilities could also be provided at the repository, at the potential MRS facility, or could be a stand-alone facility at a centralized location. Additional research is needed to determine the costs and feasibility of this concept. 


\subsection{COMMERCIAL IRU WASTE INYENTORY AND CHARACTERISIICS}

This section presents the results of a survey of conmercial senerators of TRU wastes. Also included in the survey are wastes generated at corminercial facilities that may be accepted in the future by the DOE. The wastes are categorized as either nuclear fuel-cycle or non-fuel-cycle wastes. Fuel-cycle wastes are defined as TRU wastes generated at commercial nuclear facilities including power reactors, fuel reprocessing facilities, and fuel fatrication plants. Non-fuel-cycle wastes are defined as TRU wastes generated by manufacturers of equipment and devices that contain TRU isotopes. Some exampies include companies that fabricate radiation sources, smoke detectors, well-logging devices, and medical devices such as plutonium-powered heart pacemakers. Brief discussions of the sources of these wastes are presented in this section. Summary tables of TRU naste inventories are presented in Appendix A. It should be noted that English units are used extensively in this section and in Appendix A. This is primarily because the waste generators contacted in this study also used English units. Where appropriate, metric-to-English conversion factors are provided. All of the IRU waste inventory data collected during the survey is included in the following section or in Appendix $A$.

\subsection{BASES}

The TRU waste-inventory, production rate, and characteristics data were obtained from a survey of facilities that generate TRU wastes. A previous survey by Hazelton(a) was used as a starting point for collection of additional data. It was found that the TRU waste producers could be divideo into two main groups: those that are or were involved with the comercial ruclear fuel cycle and those that are not. Under these two main categories, individual waste producers were further divided into subcategories, as shown below:

(a) Hazelton. 1983. See page 1.2. 
Nuclear Power Plants

Fuel Reprocessing Facilities

Fuel Fabrication Facilities

Monitored Retrievabie Storage

Facility
Commercial Research Laboratories

Industrial users of TRU Isotopes

Information regarding the wastes produced by these facilities was obtained through Titerature reviews and discussions with personnel at the facilities. An attempt was made to estimate the quantities and characteristics of LLW generated by these facilities that may exceed the 10 CFR 61 Class C 1 imits for shallow 1and burial. Wastes that exceed the $\mathrm{Class} \mathrm{C}$ limits require special provisions and NRC approval for disposa? in a LLW burial ground. Although some of these waste may be acceptable for shallow land burial, they are al so consiaered candidates for deep geologic disposal. This information was tabulated and examined to estimate the quantities and characteristics of commercial TRU wastes and greater-than-Class-C LLW. These wastes are discussed in Section 3.3 .

The repository design basis requires development of an estimated schedule for disposal of TRU wastes. It is assumed that the TRU wastes will be received at the repository over a 20 -year period. This is slightly different than the 25-year period planned for spent fuel disposal operations but it is believed that spent-fuel disposal will receive the highest priority (this woutd alleviate some concerns of nuclear utilities that are currently running out of spent-fuel storage space at their reactor sites). The assumed 20 -year receipt period will provide a bounding value for the TRU waste receipt rate.

To estimate the TRU waste receipt rate, the total inventory of conmercial TRU wastes in the year 2022 (2022 is the final year the first repository will be receiving radioactive waste; DOE 1985) was calculated using the current inventory and the annual waste production rates for each producer. The methods 
used to estimate TRU waste production rates are specific to each facility and are discussed in detail in Sections 3.2 and 3.3. The total inventory in 2022 was then divided by the assumed TRU waste receipt period for the repository (i.e., 20 years).

\subsection{NUCLEAR FUEL CYCLE WASTES}

The nuclear fuel cycle sources of TRU wastes for disposal in the first repository include (1) commercial power reactors, (2) a high-level waste treatment demonstration project, (3) decontamination and decommissioning (D\&D) of other fuel cycle facilities that have become contaminated with TRU radionuclides, and (4) the potential MRS facility. The following subsections present the information collected about these waste generators.

\subsubsection{Nuclear Power Plants}

TRU radioisotopes generated during normal nuclear power plant operations usually remain within the $\mathrm{UO}_{2}$ fuel pellets. TRU radionuclides may escape from the fuel pellets if the fuel cladding fails or is otherwise breached. The amount of TRU isotopes released from a failed fuel rod is usually small enough that when the nuclides are removed from the reactor coolant or spent fuel storage pool water (depending upon where the fuel failure occurs), the resulting concentrations in filter media or ion exchange resins are extremely low. This observation is based on results of radionuclide analyses of low-level waste samples from operating nuclear power plants reported by $\mathrm{Cline}$, Wright, and Hollcroft (1980). TRU and other nuclide concentrations were determined in that study for several categories of LLW generated at 25 nuclear power plants. Samples from evaporator bottoms, resins, filter sludge, smears and swipes, and reactor coolant insolubles were inciuded in that study. Their results showed that mean and median concentrations of the nuclide of most concern, Pu-Z39, for each category of solid waste are significantly below $10 \mathrm{nCi} / \mathrm{g}$. Since $\mathrm{Cline}$ et a1. (1980) included plants with a history of significant fuel failures, these results are believed to be applicable to most plants. 
Cline et ai. (1980) reported that less than 4 percent of all of the wastes analyzed had $\mathrm{Pu}$ concentrations greater than $10 \mathrm{nCi} / \mathrm{g}$. Even less than 4 percent of the wastes would be expected to contain over $100 \mathrm{nCi} / \mathrm{g}$ (the EPA definition of TRU wastes in 40 (FR 191). The study analyzed dried samples of waste which had not been diluted with any immobilization agent such as concrete. If these samples had been mixec with other wastes and immobilized, the Pu concentrations would be reduced further. In addition, most of the samples that contaired concentrations above $10 \mathrm{nCi} / \mathrm{g}$ were atypica?; for example, three primary filter sludge samples from a plant that had experienced recent and substantial fuel failures and three resin samples from a plant experiencing difficulties with its radioactive waste evaporation and fuel pool cleanup systems. Since the volumes of untreated resins and $f$ ilter sludges generated by nuclear fower plants are very small $\left(0.009\right.$ to $0.16 \mathrm{~m}^{3} / \mathrm{MHe}-\mathrm{yr}$ and 0.004 to $0.22 \mathrm{~m}^{3} / \mathrm{MWe}-\mathrm{yr}$, respectively) it is 1 ikely that mixing and solidification will produce wastes with TRU isotope concentrations less than $100 \mathrm{nCi} / \mathrm{g}$. Thus, it appears that commercial nuclear power plants generate little or no wastes that woulc be classified as TRU after it has been mixed and solidified.

The Hazelton(a) survey supports the conclusions discussed above with a few exceptions. Hazelton surveyed 12 nuclear utilities representing 28 nuclear power plants and only two plants reported they were certain they had some TRU wastes. One plant. Three Mile Island-2, is atypical in that the wastes were not generated during normal power operations. The significant fuel failures that occurred at TMI-2 resulted in relatively large amounts of TRU contaminaticn being released to the reactor coolant. Clearup operations are expected to produce TRU contaminated filters, resins, sludge, and metal wastes. A planning study conducted by EG\&G was used to obtain TRU waste data. (b) In some cases, insufflcient data were contained in the planning study to determine if specific wastes would be classified as TRU. To be conservative, these wastes were assumed here to be classified as TRU wastes. More recent data was presented by Snyder (1984) which indicated the volume of TRU waste may be as

(a) Hazelton. 1983. See page 1.2.

(b) E.G.\&G. Idaho, Inc. 1982. Elanning Study-Solid Waste_Disposal Characterization for IMI-2, TPO.TMI-025 Rev. 0 (Draft), Idaho Falls, Idaho. 
high as $57 \mathrm{~m}^{3}$ (2000 $\left.\mathrm{ft}^{3}\right)$. The EG\&G estimate was increased to al ign with this value. The breakdown of different vaste types was also revised upward by multipiying by the ratio of volume presented by Snyder (1984) to the volume presented by EG\&G. (a) The revised volumes are smajl, as shown in Table 3.1 .

IABLE 3.1. TRU Waste Volumes Resulting From TMI Cieanup

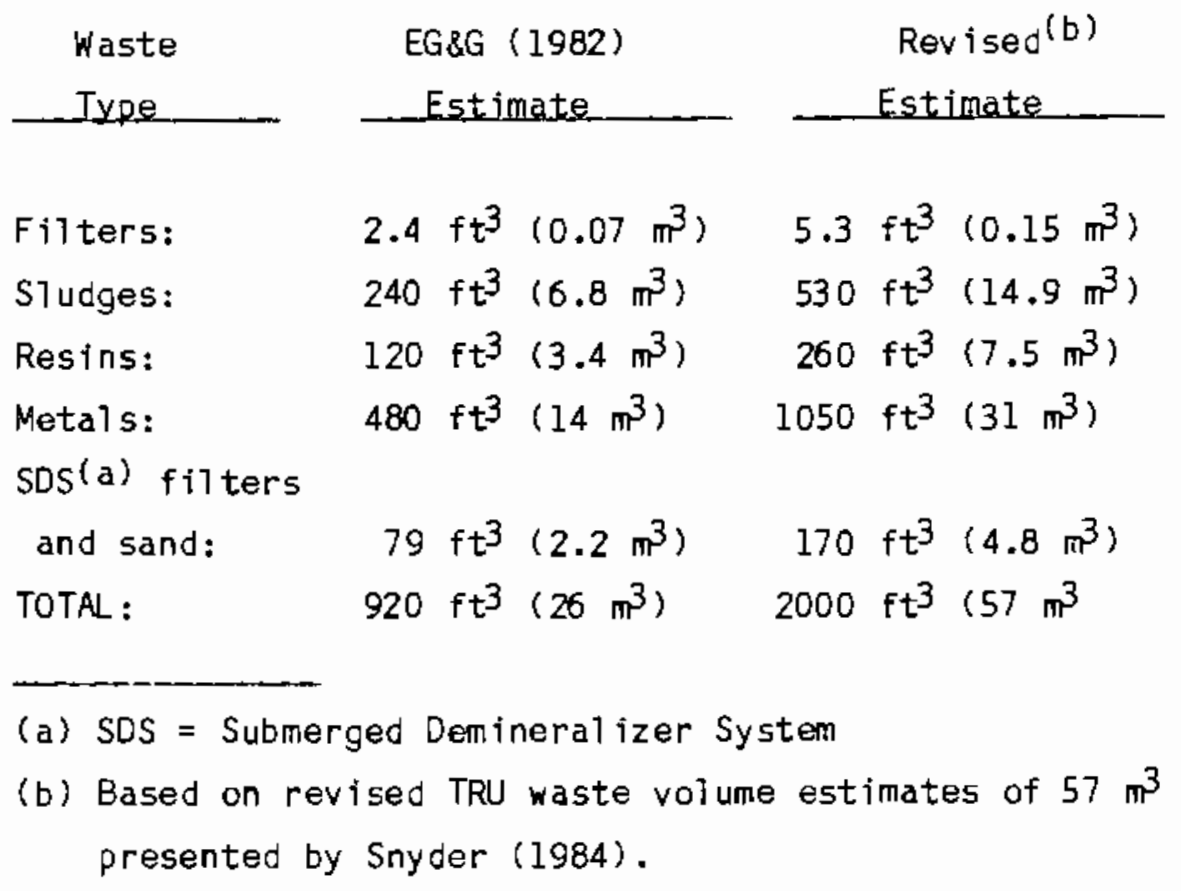

It should be mentioned that the estimates shown above represent untreated and unpackaged waste volumes. Final packaged waste volumes will be greater.

Packaged waste volumes for the TMI-2 wastes were estimated as follows. A volume increase factor of 2.1 was applied to the filters, resins, and siudges to account for mixing and solidification. The raticnale used for developing the volume increase factor is presented later in the report. The various waste forms were also assumed to be packaged in 55-gal drums. Metal wastes were assumed to be cut and/or disassembled to sizes that fit into a 55 -gal crum. A

(a) E.G.8G Idaho, Inc. 1982. See page 3.4 . 
50 percent packing fraction was assumed for the drummed metal wastes. The resulting treated waste volume estimates are shown in Table 3.2.

IABLE 3.2. Treated Waste Quantities Fron TMI Cleanup

$\begin{array}{lcc} & & \begin{array}{c}\text { Estimated } \\ \text { Number of } \\ 55-g a l \text { Drums }\end{array} \\ \text { Filters } & 11.0(0.3) & 2 \\ \text { S1udges } & 1060(30.0) & 150 \\ \text { Resins } & 520(15.0) & 75 \\ \text { Metals } & 2100(62.0) & 300 \\ \text { DS Filters and Sand } & 340(20.0) & 50 \\ \text { Rounded Totals } & 3860(117.0) & 577\end{array}$

Hazelton's survey(a) also identified a second nuclear power plant that had some filters and sludges with TRU activities in the range of $330-500 \mathrm{nCi} / \mathrm{g}$. The untreated volumes reported by Hazelton were $200 \mathrm{ft}^{3}\left(5.7 \mathrm{~m}^{3}\right)$ for filters and $200 \mathrm{ft}^{3}\left(5.7 \mathrm{~m}^{3}\right)$ for siudges. Final treated volumes were reported as $420 \mathrm{ft}^{3}\left(12 \mathrm{~m}^{3}\right)$ for both waste types. Thus, a total of $840 \mathrm{ft}^{3}\left(24 \mathrm{~m}^{3}\right)$ of these wastes are at this power plant. The nurnber of waste containers represented by this treated waste volume is about 115 55-gal drums.

A waste volume increase due to treatment and packaging can be estimated from the above data by dividing the packaged volume by the unpackaged volume. The result is a volume increase factor of 2.1 due to treatment and packaging of filters and sludges. This factor was appifed previously to filter and sludge wastes generated during decontamination of TMI-2.

(a) Hazelton. 1983. See page 1.2. 
The TRU waste inventory data from utilites that was collected during this study is presented in Appendix A (see Table A.1). These data form the basis for caiculating the current TRU waste inventory at all power plants and the future TRU waste generation rates. The method used to calculate the current inventories and future generation rates is discussed in Section 3.4.

TRU wastes could potentially be generated wen nuclear power plants are decommissioned. A recent study that included sampling and measurement of residual radionuclide distributions at Humboldt Bay found some TRU nucilides in reactor piping systems (Abel et a1. 1983). The largest inventory of TRU nuclides was found in the shutdown (or residual heat removal) cooling system. Trace amounts of Am-241 were also found in the condenser and spent fuel storage pool. The study concluded that all materials, with the possible exception of the pressure vessel and internals, could be disposed of as LLW at shallow land burial sites. However, the inventory estimates did not consider the pressure vessel and internals, contaminated concrete, materials stored in the spent fuel pool, or sludges that may be present in sumps, storage tanks, spent fuel pool, or other locations. Consequently, additional research is needed to define inventories and radionuclide distributions for these materials.

A similar study was performed at the Indian Point-l (IP-1) nuclear power plant (Lepel et al. 1984). The results of this study indicated that approximately $0.015 \mathrm{Ci}$ of TRU elements remain at IP-1, including $0.0065 \mathrm{Ci}$ of $\mathrm{Am}-241,0.049 \mathrm{Ci}$ of $\mathrm{Pu}-239$ and Pu-240, $0.0029 \mathrm{Ci}$ of $\mathrm{Pu}-238$, and $0.00078 \mathrm{Ci}$ of $\mathrm{Cm}-244$. This represents about 0.01 percent of the total resiaual radionuci ide inventory at IP-1 of $190 \mathrm{Ci}$ (mostly Co-60 and Fe-55). The inventories in the reactor vessel, biological shield, concrete surfaces, residues, sludges and resins in tanks and sumps, and the irradiated fuel are not included. The TRU activities are contained primarily in the primary coolant system pifing and associated equipment (excluding the reactor core).

Lepel et al. (1984) al so performed some comparisons of radionuclide concentrations at IP-I with the Class A LLW burial limits (see 10 CFR 61). 
Class $\mathrm{A}$ wastes have the lowest concentration 1 imits and are the least restrictive for disposal. The comparisons indicated that the residua? radionucilde levels found on contaminated piping never exceeded the $\mathrm{Cl}$ ass $\mathrm{A}$ limits. Therefore, it appears that contaminated piping, which is the location of the vast majority of TRU isotopes, will be acceptable for disposal in a shallow land burial ground. The average concentration of Cs-137 would be significantiy lower after mixing with concrete that is contaminated with much lower levels of Cs-137.

It is concluded from this information that only smal1 amounts of TRU wastes, if any, would be generated by decontamination and decommissioning of nuclear power plants.

\subsubsection{Fuel Reprocessing Facilities (West Valley Demonstration Project)}

The West Valley Demonstration Project (WVDP) will demonstrate the retrieval, solidiffcation, storage, transport, and disposal of liquio highlevel wastes (HLW) currently being stored in tanks at the Western New York Nuciear Service Center (West Valley). Transuranic wastes will be generated in all phases of the demonstration, including pre-solidification (initial decontamination), solidification (HLW processing), and post-solidification (fina? decontamination and decommissioning) phases. Although this project and the waste generated is being handled by the DOE, it is a product that results from commercial activities. Thus, there is some uncertainty regarding the fina] disposition of the TRU wastes (i,e., disposa? in a civilian or the WIPP repository). However, it has been decided that vitrified West Valley HLW will be disposed of in a commercial repository.

West Valley Demonstration Project TRU waste generation estimates were extracted from a draft preconceptual design report and from Cwynar et al. (1984). These reports indicated that a total of approximately $70,000 \mathrm{ft}^{3}$ (packaged waste volume) of TRU wastes will be generated. About 60 percent of 
these wastes will be generated during finat cecontamination and decommissioning operations, 30 percent during initial decontamination, and the remainder during HLW processing operations.

The bulk of the TRU wastes will be treated in some manner prior to final packaging. Current plans are to compact LLW general rubbish and trash into $1.9 \mathrm{~m}$ $\times 1.2 \mathrm{~m} \times 1.3 \mathrm{~m}$ rectangular steel boxes (Cwynar et al. 1984). TRU wastes are not pianned to be compacted because of the contamination risk. It is planned that 7 iquid wastes, such as decontamination solutions, will be filtered, dewatered (evaporation), demineralized and soljdified in cement (Cwynar 1984). The WVDP plans to use a $f l u i d i z e d$ bed dryer (FBD) to process evaporator concentrates and processed neutralized decontanination solutions. The dried wastes from the FBD, as well as filter sludges and spent ion exchange resins, will be solidified with cement and cast into 55-gal drums. Metallic wastes, such as contaminated chemical processing equipment and hardware, failed HLW processing equipment and hardware, and waste retrievai equipment, will be decontaminated and dismantled to the extent possible and cut where needed to sizes that will fit within the steel box mentioned above. Contaminated rubble from building demolition during the post-solidification phase are planned to be packaged without treatment in two metal box sizes $(1.9 \mathrm{~m} \times 1.2 \mathrm{~m} \times 1.3 \mathrm{~m}$ and $1.7 \mathrm{~m} \times 1.4 \mathrm{~m} \times 1.0 \mathrm{~m}$ respective1y). Waste generation estimates are summarized in Appendix $A$.

The physical properties of the treated TRU wastes are uncertain at this time. However, the preconceptual design report mentioned previousiy assumed the following densities for the various waste forms:

- Wastes solidified in binder (cement) - $1600 \mathrm{~kg} / \mathrm{m}^{3}$

- Compacted wastes - $480 \mathrm{~kg} / \pi^{3}$

- Contaminated rubble - $800 \mathrm{~kg} / \mathrm{m}^{3}$

- Contaminated equipment/hardware $-320 \mathrm{~kg} / \mathrm{m}^{3}$.

Radiolsotope distributions are not available for these wastes. However, estimates of the surface dose rates of the various waste containers have been 
developed. The maximum surface dose rate is $50 \mathrm{R} / \mathrm{hr}$ for solidification resins and filters. It is estimated that over 50 percent of the $55-g a l 1$ on drums, 50 percent of the 1 iners, and none of the boxes will be RH-TRU wastes (i.e., surface dose rate exceeds $200 \mathrm{mR} / \mathrm{hr}$ ). The remainder will be $\mathrm{CH}-\mathrm{TRU}$ wastes.

\subsubsection{Decontamination and Decomissioning of Former Mixed Oxide Fue] Fabrication Facilities}

A number of commercial nuclear fuel fabrication facilities were used in the past to fabricate small amounts of mixed ( $U$ and $P U$ ) oxide (MOX) fuel elements. Since commercial reprocessing is not a viable business at this time, most of the MOX fuel fabrication facilities have been mothballed. Ultimately, these facilities will be decontaminated and decommssioned. The final disposition of these wastes is uncertain because the companies that operated the Mox facilities are not contributing to the Nuclear Waste Disposal Fund set up by the NWA. It is assumed here that the TRU wastes generated during decontamination and decomissioning of these facilities will require repository disposal. Much of the information in this section was obtained from proposals developed by the Mox facility operators to perform decontamination and decommissioning demonstrations for DOE in exchange for DOE disposing of the wastes. Summaries of the IRU waste inventory data from these proposals are presented in Appendix A. It shoula be noted that Hazelton(a) contacted several operators of uranium fuel fabrication plants who indicated that they had no commercial TRU wastes. These facilities were not contacted during the present survey.

Nuciear Fuel Services, Inc.

In May 1983, Nuclear Fuel Services, Inc. (NFS), submitted an unsolicited proposal to the DOE to undertake a research and development program involving a large-scale decontaminaton and decommissioning demonstration. The proposed demonstration will involve part of NFS' facilities at Erwin, Tennessee, which were used in the late 1960 s and early 1970 s to manufacture plutonium fuel for

(a) Hazelton. 1983. See page 1.2. 
the DOE. The proposed decontamination and decommissioning demonstration will generate some TRU wastes which may require repository disposal. The proposal indicates that NFS wi11 perform the demonstration for the DOE and in exchange for the information to be gained, DOE will accept all TRU wastes resuiting from the program. Negotiations are in progress.

The NFS proposal contains estimates of TRU waste generation rates expected during the demonstration. NFS's overall objective during the demonstration will be to reduce the amount of TRU contaminated wastes to the smallest practical volume. The major types of TRU contaminated materials include glove boxes and associated equipment and the concrete building. Glove boxes and associated equipment represent the bulk of the volume of contaminated materials (approximately 40,000 $\mathrm{ft}^{3}$ untreated waste volume). Treatment of these waste types includes:

- removing and bagging material and equipment currently within the glove boxes

- cleaning glove boxes with high pressure spray

- fixing the contamination by spraying with a fixative

- detaching the glove box

- removing noncontaminated external hariware

- removing HEPA filters

- sectioning and disassembling the glove box

- decontaminating by vibratory finishing and/or electropolishing

- sorting according to contamination level

- packaging.

The untreated TRU waste forms will inciude metals, plexiglass panels, HEPA filters, and 1 iquid IRU wastes from vibratory finishing and electropolishing operations. 
In addition to glove boxes, nearly $30,000 \mathrm{ft}^{2}$ of contaminated concrete surface will be decontaminated. The concrete surface wi1l be decontaminated using a two-step spalling technique that removes only the contaminated outer layer. The decontaminated wall may be disposed of or resurfaced. Concrete decontamination is not anticipated to generate TRU wastes; oniy low-level wastes are expected.

The NFS proposal estimates that approximately $5300 \mathrm{ft}^{3}$ of TRU wastes will result from the proposed demonstration. These wastes will be packaged to meet DOE's TRU waste acceptance criteria for interim storage and disposal. For this study, it is assumed that all TRU wastes from this demonstration will be packaged in 55-galion orums. This assumption appears reasonable because the decontamination and decommissioning project will include cuting and sectioning of the larger metallic wastes. Thus, the large components may be cut into small enough pieces to fit into a $55-\mathrm{gal}$ crum.

Based on the above discussion, the bulk of the IRU wastes will be packaged with minimum treatment. Current plans do not include provisions to compact metallic wastes or HEPA filters. It is assumed that liquid TRU wastes will be dewatered in some manner and solidified with cement or other appropriate solidification agent. Additional treatment may be required for these wastes to meet the repository waste acceptance requirements developed in Section 4.0 .

\section{Exxon Nuclear}

Exxon Nuclear Co., Inc., plans to decommission a mixed oxide fuel fabrication facility that has been in mothball status since 1977. Exxon proposed to the DOE that the glove boxes and other associated equipment be decontaminated to below low-level waste burial limits after immobilization with concrete. However, Exxon expects some TRU wastes to result from the decontamination effort. These wastes be packaged in DOE-approved waste containers. 
Exxon estimates that about $1305 \mathrm{ft}^{3}\left(37 \mathrm{~m}^{3}\right)$ of mixed-oxide contaminated equipment are present at the facility. These wastes include glove boxes, glove box connectors, a sintering furnace and associated equipment, exhaust ports, ducting, valves, and filter boxes. These materials will be decontaminated as necessary to meet low-level waste burial regulations after stabilization. Also contained within the glove boxes are miscellaneous equipment items and cleaning tools that cannot be left within the glove boxes without exceeding LLW Jimits. Exxon proposes to bag these metallic IRU waste materials and place the bags in 55-gallon drums. Approximately $250 \mathrm{ft}^{3}$ (34 55-galion drums) of TRU wastes are expected. At this time, there are no plans for treating these TRU wastes.

\section{Babcock and $W i l c o x$}

Babcock and Wilcox (B\&W) also subnitted a proposal to DOE regarding development of decontamination technology in exchange for DOE acceptance of certain TRU wastes for disposal. These wastes will result from decontamination of the B\&W plutonium fuels development laboratory in Lynchburg, Virginia. B\&W is currentiy decontaminating this facility. They proposed to develop technology (methods, processes, equipment, and procedures) to support decontamination and decommissioning of fuel fabrication plants and radioactive waste treatnent activities.

The performance of the decontamination project has resulted and $w i 11$ continue to result in IRU contaminated wastes. All TRU wastes will be in solid form and packaged in 55-gallon drums. A71 wastes wi1l be packaged and certified using the Waste Isolation Pilot Plan (WIPP) - Waste Acceptance Criteria (Westinghouse 1984). The proposal indicates that up to 210 55-gallon drums of the waste material will be generated during the decontamination operations.

The proposal contains little data regarding the characteristics of the IRU wastes that have been or will be generated. The proposal does indicate the 
radioactive wastes include material resulting from decontamination of the laboratory building, its contiguous grounds, and its associated facilities. Thus, the types of wastes expected to be generated are as follows:

- concrete, building rubble

- soit

- metallic equipment (e.g., sectioned glove boxes and associated haroware)

- decontamination solutions (used primarily to remove epoxy faint and floor tile cement from masonry surfaces).

Treatment of these wastes is expected to be minima?. Decontamination solutions are assumed to be dewatered and solidified while the remaining wastes will be essentially packaged without treatment.

\section{Sequoyah Fuels Corporation}

Sequoyah Fuels Corporation (formerly Kerr-McGee) is presently in the final stages of a D\&D demonstration program involving their mixed oxide fuel facility near Oklahona City, Oklahoma. Hazelton(a) reported that 44255 -gallon drums were on hand with an additional 1400 drums anticipateo to be produced. Thus, up to about 1840 drunis totaling $16,600 \mathrm{ft}^{3}$ of TRU wastes are estimated to be produced. These wastes include sectioned glove boxes, storage tanks, pulse columns, filters, plastics, and wipers. The untreated waste forms include metais, plastics, glass, and celluiosic materials. It is not known if these wastes were treated before packaging. However, the wastes will be in solid form and certified using the WIPP-Waste Acceptance Criteria (Westinghouse 1984).

\subsubsection{Dry Spent. Euel Rod Consolidation Facilities}

DOE-OCRWM is currently evaluating the concept of disassembling spent fue? elements, separating the fuel rods from non-fuel-bearing components, placing the

(a) Hazelton. 1983. See page 1.2 . 
fuel rods into a canister in a close-packed array to reduce the volume of spent fuel emplaced in a repository, and disposing of non-fuel-bearing components as required. This process is called rod consolidation and it may ultimately be performed at the potential MRS facility or at the repository. The potentia? exists during this process for one or more fuel failures to cccur resulting in contamination of process areas and equipment with TRU isotopes. Other TRU wastes may arise from contanination of paper, boots, clothing, plastic bags, rags, gloves, and other combustible materials. Current plans at the potential MiRS facility are for these materials to be solidified with grout in 55-gal drums. Grout is made of sand, cement, and evaporator bottoms slurry. Spent ion exchange resins will also be generated and are planned to be solidified in cement. Other potentially combustible TRU wastes, inciuding HEPA filters and prefilters with wooden frames are expected to be compacted and placed in drums. The waste generation estimates in this report do not include the non-fuel-bearing components and hardware. These wastes are examined in a comparison report(a).

TRU waste generation data for dry rod consolidation operations were obtained from the architect-engineer (A-E) for the MRS facility design (Parsons 1985). These waste generation estimates are not expected to be significantly different than estimates based on consolidation at the repository because the unit processes and facility designs should be approximateiy the same. It is assumed here that the MRS facility will handle and process $3000 \mathrm{MTU} / \mathrm{yr}$ of spent fuel (the MRS facil ity waste generation rates were normalized to this processing rate from 3,600 MTL/yr assumed in the $A-E$ document). The estimates produced by the A-E do not distinguish between $\mathrm{CH}-\mathrm{TRU}$ waste and LLW because insufficient data is available. Therefore, these estimates are conservative because they contain wastes that may urtimately be classified as LLW and be acceptable for shallow-land burial. The waste generation data developed by the $A-E$ are shown in Table 3.3 .

(a) Luksic et al. 1985. See page 1.2. 
TABLE 3.3. Estimated RH- and CH-TRU Waste Generation Rates from the Potential MRS Facility (a)

Waste Generation Rate

Type of Waste $55-g a l$ drums/yr yolume, $\mathrm{ft}^{3} / \mathrm{yr}$

Contact-handied TRU Waste

Combustibies

Cemented Waste

HEPA Filters (wooden-framed)

Noncombustibles (failed

equipment, tools, etc.)

TOTAL CH-TRU

\begin{tabular}{rr}
221 & $\begin{array}{r}1,550 \\
207\end{array}$ \\
& 1,450 \\
9 & $\quad 60$ \\
\hline 437 & 3,060
\end{tabular}

Remote-handled TRU Waste

Combustibies

Spent Resin

Wooden HEPA Fi]ter Frames

Noncombustibles

Solidified Evaporater Bottoms

Metal HEPA Filter Frames

HEPA Fil ter Media

TOTAL RH-TRU

$\begin{array}{rr}10 & 70 \\ 39 & 270 \\ 17 & 120 \\ 523 & 3,660 \\ -562 & 3,930 \\ 1,151 & 8,050\end{array}$

(a) Source: Parsons 1985.

(b) Assume $7 \mathrm{ft}^{3}$ of TRU waste per 55-gal drum. Metric conversion factor; $1 \mathrm{ft}^{3}=0.028 \mathrm{~m}^{3}$.

The splits between $\mathrm{RH}-$ and $\mathrm{CH}-\mathrm{TRU}$ wastes were made as follaws. In-cell HEPA filters and first-stage testable filters were considered High Activity Wastes (HAW) by the A-E and are considered here to be RH-TRU wastes. HAW noncombustibles include failed equipment, broken tools, and miscellaneous items from a hot cell or equipment maintenance cell. HAw spent resins and evaporator bottoms slurry result from processing of HAW 1 iquid wastes and are processed separately from LLW/CHTRU evaporator bottoms slurry in parallel processing lines. The remaining wastes are, in general, generated in areas with lesser potential for contamination and are designated LLW/CHTRU wastes. It is planned that these wastes will be interrogated in the MRS facility to determine if they are LLW or TRI wastes. However, for conservatism, it is assurned here that al1 are classified as TRU wastes. 


\subsection{NON-NUCLEAR-FUEL-CYCLE WASTES}

This section presents the findings regarding nuclear facilities that are not involved with the commercial nuclear fuel cycle. As discussed previously, since factlities such as these do not generate electricity, they are currently not contributing to the Nuclear Waste Disposal Fund. Because of this, the ultimate disposition of these wastes is uncertain. For conservatism, these wastes were included in this survey. The wastes were categorized as commercial research laboratory wastes or wastes from other industrial users of certain TRU isotopes.

\subsubsection{Commercial Research Laboratory Wastes}

The Hazelton(a) survey reported that some commercial laboratories own TRU wastes that were generated during nuclear fuel development and testing programs. This information was updated during the current study. The two laboratories that indicated they had TRU wastes were the Battelle Memorial Institute's West Jefferson Laboratories and the Generai Electric Company's Vallecitos Nuclear Center. TRU wastes generated at these facilities are discussed below.

\section{Battelle/ West Jefferson Laborateries}

The TRU wastes currently at Battelie's West Jefferson laboratories were generated during spent fuel rod cutting operations and metallographic testing of commercial spent fuel rods. Battelie indicated by telephone that they have approximately 200 55-gallon drums of waste, of which 60 have been identified as TRU. Therefore, Battelle owns approximately $450 \mathrm{ft}^{3}$ of TRU waste. Of the

(a) Hazeiton. 1983. See page 1.2 . 
60 drums of TRU waste, it is estimated that 10 have surface dose rates in excess of $5 \mathrm{RJhr}, 17$ are in the range of 5 to $10 \mathrm{R} / \mathrm{hr}$, and the remaining 33 drums are in the range 1 to $10 \mathrm{FVhr}$. None of the TRU waste containers were identified as being contact-handled. These wastes are primarily metallic wastes that were packaged without treatment. Battelle indicated that they have no plans for treating their TRU wastes. They plan to continue to store these wastes untit provisions for their ultimate disposal are finalized.

\section{General Electric Company}

The radioactive wastes produced by the General Eiectric Company at the Vallecitos Nuclear Center (VNC) was the subject of a recent NRC-sponsored study (Kempf et a1. 1984a). This study performed detailed evaluations of the low-level and TRU radioactive wastes produced at the VNC. Radioactive wastes are generated at VNC during examination of reactor components and fuel and during production of radiopharmaceuticais and radioactive sources. A small fraction of the low-level radioactive wastes produced at VNC would be $L L W$ disposal Class $B$ or greater (see 10 CFR 61 for definitions of LLW Class A, B, and $C$, for least to most restrictive, respectively). Kempf et al. (1984a) indicate that only waste generated in hot cell facilities appear to contain sufficient levels of radionuclides to be considered $\mathrm{Cl}$ ass $\mathrm{B}$ or greater. These wastes consist of irradiated metals, glass, and general cell trash which are mainly in solid form. Compactable wastes are placed in one gallon cans and compacted prior to disposal. A very small volume (about 30 gal per year) of liquid wastes are produced from hot cell acivities. These wastes are solicified with cement in a one gallon can in a 2:1 cement to liquid ration. The wastes are piaced in $80-g a 11$ on steel orums which are subsequently filled with a cernent grout. The grout consists of 600-1b Portland cement, 600-1b sand, and 30-gal water.

Kempf et a?. (1984a) also examined the radioactive shipment recoros (which include radioisotopic contents) naintaineo by GE. It was determined that GE had shipped hot cell wastes prior to enactment of 10 CFR 61 that would have exceeded 
the $\mathrm{Cl}$ ass $\mathrm{C} 1$ imits. These wastes consisted of metal oxides and irradiated hardware in a single $80-g a l$ grouted drum that GE indicated was a one-tine event. However, for conservatism, it is assumed that GE will produce one such drum per year.

GE also has produced waste materials that may ultimately be classified as $\mathrm{RH}-\mathrm{TRU}$, including nuclear reactor irradiated $\mathrm{z}$ ircalioy-clad, $\mathrm{UO}_{2}$ fuel (intact fuel rods, fuel rod sections, pellets, and fragments) as well as some metallographic samples encased in plastic. These wastes will be essentialiy packaged without treatment. GE has indicated by letter that approximately 2000 to $3000 \mathrm{lb}$ (900 to $1400 \mathrm{~kg}$ packaged weight) of these waste materials totaling approximately $26 \mathrm{ft}^{3}\left(0.7 \mathrm{~m}^{3}\right)$ are in the1r possession. GE indicated that about 80 percent of these wastes are in $0.6 \mathrm{ft}^{3}$ ( 4.5 galion) containers and the rest is in $0.4 \mathrm{ft}^{3}(3-\mathrm{gallon})$ containers. The letter estimates that these wastes contain about $400,000 \mathrm{Ci}$ of radioactivity, of which $1600 \mathrm{C}$ a are TRU nuclides. About $3.5 \mathrm{~kg}$ of $\mathrm{U}-235$ and $0.7 \mathrm{~kg}$ of Pu are contained in the wastes. The density of packaged wastes is estimated between 75 and $115 \mathrm{ib} / \mathrm{ft}^{3}$ ( 1200 to $1850 \mathrm{~kg} / \mathrm{m}^{3}$ ) and total themal decay power is about $1.7 \mathrm{~kW}$.

GE also indicated they have a small volume of mixed wastes that would not be classified as low-level wastes for land disposal. These wastes include such items as solidified analysis solutions, abrasive cutting disks, dried grinding and polishing debris, and miscellaneous cloth and paper wastes. These wastes are packaged in $0.4 \mathrm{ft}^{3}$ (3-galion) containers. Packaged waste weight and density are estimated at about 375 to $5251 \mathrm{~b}(170$ to $240 \mathrm{~kg})$ and 60 to $90 \mathrm{lb} / \mathrm{ft}^{3}$ $\left(1000\right.$ to $\left.1400 \mathrm{~kg} / \mathrm{m}^{3}\right)$, respectively. Approximately 200 to $400 \mathrm{C} ;$ of radioactivity are contained in these wastes, of which 1 to $2 \mathrm{C} i$ are TRU nuclides. According to Kempf et al. (1984a), the average TRU isotope concentration in the solidified liquid wastes (not diluted) is approximately $1.5 \mathrm{mCi} / \mathrm{g}$, which is about $10^{4}$ times the Class $\mathrm{C} 1$ imit for these isotopes. A concentration of $3 \mathrm{mCi} / \mathrm{g}$ was given as the maximum TRU concentration in any of the VNC waste. Thermal decay power is negligible. 
GE indicated no plans for treating either the irradiated fuel or the mixed wastes. They aiso indicated that their TRU waste inventory will continue to increase, al though no annual production rate estimates were given.

\subsubsection{Wastes From Other Industrial Users of IRU Isotopes}

TRU wastes are generated during the fabrication of radiation sources, heat sources, well-logging devices, and other equipment that contain IRU radionuciides. Hazelton(a) reported that, with the exception of Monsanto Research Corp., other companies that manufacture devices using TRU isotopes produce only small quantities of TRU wastes if any. The Hazelton(a) survey was updated during the current study and additional information regarding TRU waste forms was obtained.

Monsanto Research Corp. fabricates radiation and heat sources using TRU isotopes at their Dayton, Ohio iaboratory. The material in their present TRU waste inventory consists primarily of production trash, with smaller quantities resulting from decontamination of working areas. Approximately 60 percent of the production trash is combustible material (e.g., paper, cardboard cartons, rags, gioves, piastics, etc). These materials are compacted by hand into l-gallon steel paint cans, placed in polyethylene bags (i.e., "bagged out") then removed from the production 1 ines. Liquid wastes are chemically stabilized and neutralized, then mixed with cement and an absorbent, placed in polyethylene bottles, and allowed to solidify before being bagged out. Solidified liquids represent less than 10 percent of the production trash. The remainder of the production trash consists of non-combustible materials such as metallic wastes (failed equipment, cans, tools, etc.). These materials are placed in l-galion metal cans and bagged out. Larger items are bagged out directiy in polyethylene bags. After the wastes are bagged out, they are placed in heavy polyethylene drum 1 iners with snap-on and adhesive-sealed lids, inside 55-gallon drums.

TRU wastes are also generated during cleaning and decontamination of working areas. These wastes include dried cleaning rags, strippabie surface

(a) Hazelton. 1983. See page 1.2. 
coatings, and small quantities of cleaning water (solidified in cement and absorbent as discussed above). The TRU wastes also include small quantities of HEPA filters and flexible (neoprene or viny 1) hose used to connect filters to the box 1 ines or ventilation system.

Monsanto reported that they currently have 76 55-gallon drums of TRU wastes and expect to generate additional TRU wastes at a rate of about 16 drums/yr. The principle radioisotopes involved are Pu-Z38 (estimated at about $10 \mathrm{~g}$ total), Am-241 (about $75 \mathrm{~g}$ ) and $\mathrm{Cf}-252$ (very small quantity). A total of $225 \mathrm{Ci}$ of activity was estimated. The approximate weight of the TRU wastes was estimated at about $5900 \mathrm{~kg}(13,000$ lbs). A11 of the TRU waste drums would be contact-handled (surface dose rate less than $200 \mathrm{mR} / \mathrm{hr}$ ).

Monsanto also indicated they have several obsolete glove box 1 ines which they would like to replace with more modern units. To do this, they would have to remove and dispose of the internally-contaminated obsolete units. Monsanto estimated that the total voiume of the glove boxes and external packaging into which they would be placed would be about $23 \mathrm{~m}^{3}$ ( $\left.800 \mathrm{ft}^{3}\right)$, or the equivalent of about 110 55-gallon drums. This material would be primarily metallic wastes that contain approximately 20 to $50 \mathrm{Ci}$ of mixed Am-24l and Pu-238. No treatment provisions for these potential wastes were indicated. The plans for removing and replacing the glove boxes will not be implemented until a means for disposal of TRU wastes is available.

TRU isotopes are also utilized in the fabrication of certain medical and industrial cevices. Some examples include well-logging devices, plutonium-powered heart pacemakers, smoke detectors, and other devices which use TRU isotopes as a neutron or heat source. The results of a survey of organizations that make or handle such equipment (see Appendix A) indicated that, in general, they handle only relativeiy small amounts of TRU isotopes. Thus, only small amounts of TRU wastes would be generated. The survey also indicated that, due to the high cost of these isotopes, they are carefully reclaimed and recycled back into the production Tine. Since most of the TRU 
isotopes are recycled, disposal of any resulting radioactive wastes can generally be accomplished as LLW at a near-surface disposal facility.

Gause et a1. (1983a) analyzed the waste produced by Union Carbide Co. (UCC). UCC produced Mo-99 for use as radioactive tracers by the fissioning of U-235. Essentially three types of waste, 1) neutron-activated stainiess steel target material, 2) hot cell processing items, and 3) cement-solidified liquid wastes are poduced. The liquid wastes are produced from separation and purffication of Mo-99 and are contaminated with fission products, uranium isotopes, and Pu-Z39 (from activation of U-238; UCC indicates Pu-239 is the only significant TRU isotope they produce). The liquid wastes are solidified in cement in a way that results in a Pu-Z39 concentration below $10 \mathrm{nCi} / \mathrm{g}$. The solid wastes are contaminated with insignificant quantities of Pu-239. Therefore, UCC does not generate any TRU wastes. Gause et a1. (1983a) also concluded that the wastes produced by UCC are within Class B LLW burial limits (10 CFR 61). It is noted that UCC in 1979 shipped iess than 1 percent of the U.S. LLW to shallow land burial but contributed about 15 percent of the activity (Gause et a1. 1983a). This indicates that a large fraction of the LLW produced in the U.S. is relatively low activity wastes and is not expected to exceed 10 CFR 61 Class C 1 imits.

A similar evaluation (Kempf et al. 1984b) was performed on the wastes generated by the Minnesota Mining and Manufacturing Co. (3M). 3M produces radicpharmaceuticals, radioactive implants, and radioactive sources. Kempf et a1. (1984b) found that $3 M$ had shipped waste to disposal that contained Co-57, Po-210, Tc-99, Cs-137, Sr-90, natural thoriun, and mixed fission products. Although none of these are TRU isotopes, it was found that some of the wastes may have exceeded $10 \mathrm{CFR} 61 \mathrm{Class} \mathrm{C}$ limits prior to its implementation. Kempf et a1. (1984b) analyzed 3M Radioactive Shipment Records over an 18 month period and calculated that $8,550 \mathrm{ft}^{3}$ of waste containing 2,299 $\mathrm{Ci}$ were shipped. This suggests an annual waste production rate of approximately $5,700 \mathrm{ft}^{3}$. It was found that one $30-\mathrm{gal}$ drum contained $\mathrm{Cs}_{s}-137$ concentrations that exceeded 
the $\mathrm{Class} C 1 \mathrm{imit.}$. For conservatism, it is assumed that $3 \mathrm{M}$ produces one of these containers annualiy that exceed the Class C 1 imits. This particular type of waste is produced in hot cell processing operations and consist primarily of plastic (50\%); HEPA filters (10\%); and glass, paper, and metal wastes (40\%). These wastes are essentially packaged without treatment in 1ead-1ined, 30-gal drums.

Gause et a1. (1983b) performed similar analyses of the waste generated by the New Engl and Nuclear Corp. (NENC). NENC produces, in addition to other products, $\mathrm{H}-3$ and $\mathrm{C}-14$ labeled compounds. Several types of NENC wastes were characterized. The largest portion was determined to fall within $10 \mathrm{CFR} 61$ Class A or B limits and are acceptable for disposal in a commercial burial ground. However. NENC also produces a high-activity gaseous waste package that contains greater than $100 \mathrm{C} 1$ of gas (primarily $K-3$ ) and thus does not meet the minimum requirements of 10 CFR 61 . These gaseous wastes are contained within flame-seajed glass bulbs which are placed in sand within a tin can. The tin cans are then stacked in a 55-gal drum and cement is poured around the cans to give a 6-in. thick concrete layer around them. Each drum was estimated to contain between 20 and $1000 \mathrm{Ci}$ of gaseous radioactivity. These waste are not expected to be acceptable for disposal at either a LLW burial ground or repository because of the gaseous content of the wastes. Therefore, they require further treatment, which is anticipated to result in wastes that are acceptable for shallow land burial. NENC al so indicated in the Hazelton(a) survey that they produce and store small volumes of TRU-isotope contaminated wastes onsite. Am-241 is the principal TRU isotope. They indicated that they have approximately $350 \mathrm{ft}^{3}$ of TRU waste onsite, primarily combustible laboratory trash, such as gloves, booties, and wipes. According to Gause et al. (1983b), NENC disposed of approximately 80,000 nanocuries of AM-241. It is conservatively estimated that NENC produces approximately $50 \mathrm{ft}^{3}$ of $\mathrm{TRU}$ wastes per year.

(a) Hazelton. 1983, See page 1.2. 
An annual production rate of greater than $\mathrm{Cl}$ ass $\mathrm{C}$ wastes from industrial users can be estimated as follows. Because they are involved in so many diverse applications, the wastes generated by $3 \mathrm{M}$ were assumed to be typical of producers of radiopharmaceuticals and radioactive sources, even though it has been shown that $3 M$ wastes are typically more radioactive than others. The annual waste generation rate (greater than $\mathrm{Class} C$ ) was estimated by multiplying the total LLW volume produced annually by all industrial users of radioisotopes by the ratio of the greater than Class $C$ wastes to the tota] LLW volume produced annuai7y by $3 \mathrm{M}$. This ratio of 3M's greater-than-Class-C to all LLW is $1 / 1425$ or $7.0 \times 10^{-4}$. According to DOE, a total of approximately $40,000 \mathrm{M}^{3}$ of (1.4 million $\mathrm{ft}^{3}$ ) of commercia) LLW was generated by non-fuel-cycle industrial users of radioisotopes in 1983 (DOE 1984). Therefore, the annual generation rate of greater than class $C$ wastes from industrial facilities is estimated at $28 \mathrm{~m}^{3} / \mathrm{yr}\left(1000 \mathrm{ft}^{3} / \mathrm{yr}\right)$.

According to data reported by Baker (1984), Am-24l and Pu-238 are the TRU isotopes in the greatest demand in the commercial sector $(485,000 \mathrm{~g}$ and $42 \mathrm{~g}$, respectively, sold in FY 1983). By far the greatest quantity of Am-241 is used in neutron sources; the largest use is in the petroleum industry for well logging (Mengeng and Thayer 1984). Neutron sources contain up to $20 \mathrm{Ci}$ or $6 \mathrm{~g}$ of Am-24l. The most widespread use of Am-24l is in home smoke detectors. However, only about 2.7 micrograms of Am-241 is used in any one srioke detector so only approximately five grams per year is used for this application (Mengeng and Thayer 1984). Most of these radioisotopes are produced at the Oak Ridge National Laboratory (ORNL) and sold to private organizations. The results of the survey of these organizations are shown in Appendix $A$.

Sealed neutron and heat sources are not generally considered a waste. However, after a private organization completes work that used a sealed source or, alternatively, if a certain type of source becones obsolete, they may wish to dispose of one or more sources. If an organization wishes to dispose of a source, it sends it to the DOE's Savannah River Plant. There the source will be appraised for potential economic recovery. If it is determined that it is 
cost-effective to recover the TRU isotopes, the source is shipped to the Los Alamos National Laboratory (LANL) for reprocessing. The sources for which it is not cost-effective to recover the TRU isotopes are placed in retrievable storage at a DOE facility. The non-recoverable sources will ultimately be disposed of in a geologic repository (WIPP or civilian repository).

In order to estimate the quantities of TRU isotope sources that will require disposal, a report entitied hjstinc of Sealed Sources by Radioisotope as of December 31, 1981 was obtained. This document is a computerized 1isting of a11 authorized companies that handie DOE sealed sources. The sources of interest are classified as either Type 50 (Pu-239 and Pu-24l) or Type 83 (a) 11 Pu isotopes). Type 83 sources are considered obsolete and are being replaced by a non-TRU isotopic source. The survey also indicated that Type 50 sources with Pu inventories greater than $15 \mathrm{~g}$ are reprocessed. The quantities of these sources that were determined to be wastes are thus the sum of the Type 83 sources and Type 50 sources with less than $15 \mathrm{~g}$. The results are as follows:

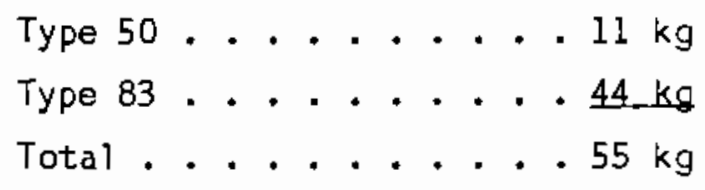

\subsection{PLANNING BASE EOR GEOLOGIC DISPOSAL REQUIREMENTS}

This section presents a preliminary recommendation for a planning base for the geologic disposal requirements of the TRU wastes generated without fuel reprocessing. Because of the limited data available, it should be clear that there is a large uncertainty regarding the actual volumes and characteristics of these wastes. The waste volume estimates for all categories of wastes except those generated at the potential MRS facility may be low by as much as a factor of two. The MRS facility waste generation rates are conservative because they include wastes that may ultimately be classified as LLW. 
The recommended planning base for geologic disposal of civilian TRU wastes is presented in Table 3.4. The table summarizes the existing waste volumes for those facilities that currently possess TRU wastes and the projected waste volumes for those facilities that are expected to generate TRU wastes on a one-time basis in the future (1.e., "special-case" quantities; includes West Valley and the fuel fabrication piant D\&D projects). Af so shown are estimated annual TRU waste generation rates, principle waste forms, approximate TRU isotopic contents, and radiation levels from sources that are expected to routinely generate $5 m a l 1$ quantities of TRU wastes. Where applicable, data regarding commercial LLW that exceeds the $10 \mathrm{CFR} 61 \mathrm{Class} \mathrm{C}$ radionuclioe concentration limits is included in the table.

The estimate of annual TRU waste generation rate from commercial nuclear power plants was based on the number of reactors currentiy operating, the current number of plant-years of operating experience, and the future number of plants if all plants operating and under construction are included. The estimated waste generation rate was calculated using the following equation:

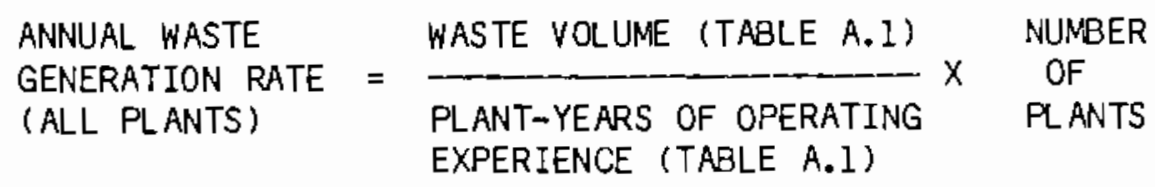

The first tem of the equation represents the average annual TRU waste generation rate per plant-year based on the operating experience of the plants listed in Table A.1. This value was then multiplied by the number of piants currently operating to estimate the current TRU waste generation rate from. nuclear power plants. The average annual TRU waste generation rate was also multiplied by the total number of plants operating and under construction to provioe an estimate of the future TRU waste generation rate. Thus, a range of TRU waste generation rates for commercial nuclear power plants is shown in Table 3.4. Again, recognize that these estimates may be low by a factor of two, except for the wastes produced at the potential MRS facility. 
TABLE 3,4. Repository Design Basis for Transuranic Nastes

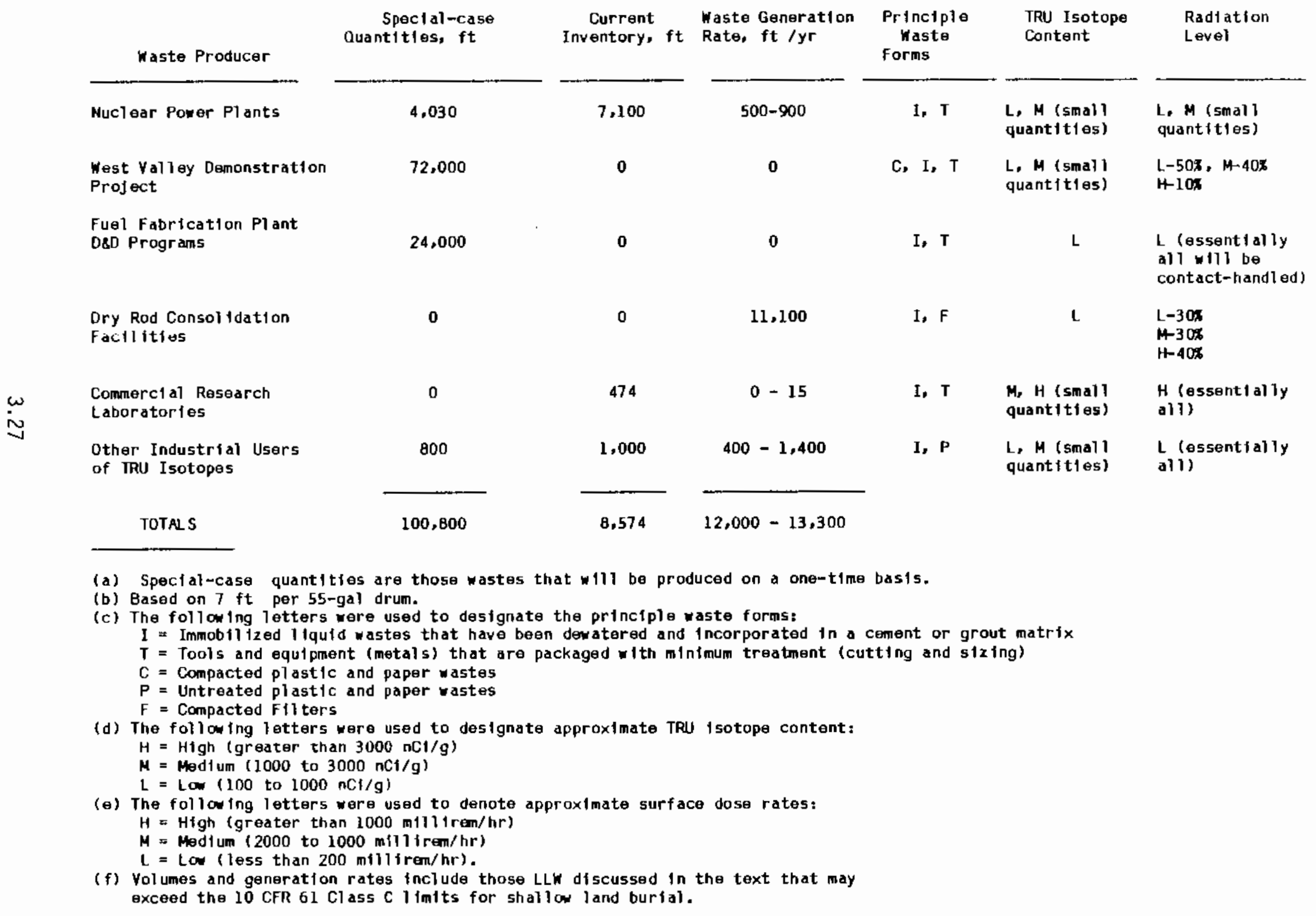


Annual waste generation rates for commercial research 7 aboratories and other industrial users of TRU isotopes are also shown in Table 3.4. Most of these sources were not able to provide estimated annual TRU waste generation rates. Therefore, the estimates shown on the table were based on the ratio of the TRU waste generation rate to the current inventory for Monsanto wastes. The data for Monsanto was selected as the basis because they were able to provide relatively detailed TRU waste data as well as an approximate waste generation rate. This ratio was about 0.2 . Thus, the waste inventories shown in Tables A.4 and A.5 were multiplied by this ratio to estimate the annual TRU waste generation rate for these facilities. TRU wastes that will be generated in one-time projects, such as decontamination of obsolete glove boxes, were not included when the waste generation rate was calculated but are included in the total inventories.

Table 3.4 shows that the estimated near-term inventory of TRU and greater-than-Class C LLW includes approximately $101,000 \mathrm{ft}^{3}$ of "specialcase" wastes and $8,600 \mathrm{ft}^{3}$ of routinely generated wastes. A total waste production rate of 12,000 to $13,300 \mathrm{ft} 3 / \mathrm{yr}$, inciuding the greater-thanClass C LLW, from all sources was estimated. This waste generation rate is equivaiant to approximately 1,700 to 2,000 55-gal drums/yr. If dry rod consolidation is not impiemented, the TRU waste generation rate would be reduced to about 900 to $2,300 \mathrm{ft}^{3 / y r}$. This is a small quantity of waste, which represents the equivalent of about 150 to 400 55-gal drums per year, when compared with the throughput of a spent fuel repository (about 6,000 to 15,000 spent nuclear fuel assemblies per year, based on a throughput of 3000 MTU per year at the repository).

The estimated waste production rates were extrapolated to the year 2022 (2022 is the last year the first repository will be receiving wastes for disposal; DOE 1985) to calculate the total amount of TRU and greater-than-Class $C \mathrm{LLW}$ expected to be produced through that year. The production rates for $\mathrm{CH}-\mathrm{TRU}$ and RH-TRU wastes were estimated based on the estimated radiation 1 evels in Tabje 3.4. It was estimated that the $\mathrm{CH}-\mathrm{TRU}$ waste generation rate would 
range from about $900 \mathrm{ft} 3 / \mathrm{yr}$ in 1985 to about $13,000 \mathrm{ft} 3 / \mathrm{yr}$ in 2020 (ciry rod consolidation facilities are assumed to startup in 1998 at a $3000 \mathrm{MTU} / \mathrm{yr}$ spent fuei throughput rate). The generation rate for RH-TRU waste was estimated to range from about $65 \mathrm{ft}^{3} / \mathrm{yr}$ in 1985 to $8,100 \mathrm{ft}^{3} / \mathrm{yr}$ in 2020 . Thus, the total new additions from 1985 to 2022 was estimated at approximately 130,000 $\mathrm{ft}^{3}$ of $\mathrm{CH}-\mathrm{TRU}$ waste and $190,000 \mathrm{ft}^{3}$ of FH-TRU waste. The total inventory in 2022, including the special-case quantities and current inventory, is estimated at about $210,000 \mathrm{ft}^{3}$ of $\mathrm{CH}-\mathrm{TRU}$ waste and $230,000 \mathrm{ft}^{3}$ of PH-TRU waste. The average annual repository receipt rate, based on the assumed 20 year receipt period, is about $10,500 \mathrm{ft} 3 / \mathrm{yr}$ of $\mathrm{CH}-\mathrm{TRU}$ waste and 11,500 $\mathrm{ft}^{3} / \mathrm{yr}$ of RH-TRU waste. This corresponds to approximately 1,500 55-gal drum-equivelants per year of $\mathrm{CH}-\mathrm{TRU}$ waste and $400 \mathrm{FH}-\mathrm{TRU}$ waste canisters per year (assuming RH-TRU waste canisters hold four 55-gal drums). These receipts are best estimates and may be low by as much as a factor of two, except for rod consolidation wastes. Since the rod consolidation waste estimates include wastes that may ultimately be classified as LLW (see Section 3.2.4), the level of conservatism included in these estimates should cancel the uncertainty in the other waste volume estimates. A more comprehensive survey, including visits to actual sites, will be required to reduce this uncertainty.

Assuming that rod consolidation is not implemented, it is estimated that the $\mathrm{CH}-\mathrm{TRU}$ waste production rate would range from $850 \mathrm{ft} / \mathrm{yr}$ in 1985 to $2,200 \mathrm{ft} 3 / \mathrm{yr}$ in 2020. RH-TRU waste production rates were estimated at 65 $\mathrm{ft}^{3} / \mathrm{yr}$ in 1985 to $100 \mathrm{ft} 3 / \mathrm{yr}$ in 2020. Assuming the production rates increase every 5 years in levelized increments, the total new additions (from 1985 to 2022) were estimated at approximately $62,000 \mathrm{ft}^{3}$ of $\mathrm{CH}-\mathrm{TRU}$ wastes and $3,200 \mathrm{ft}^{3}$ of $\mathrm{RH}-\mathrm{TRU}$ wastes. The total inventory in 2022 , including the special-case quantities and current inventory, was estimated to be 140,000 $\mathrm{ft}^{3}$ of $\mathrm{CH}-\mathrm{TRU}$ and $40,000 \mathrm{ft}^{3}$ of RH-TRU wastes. The average annua 1 repository receipts rates, based on the assumed $20-y r$ receipt period, were calculated to be about $7,000 \mathrm{ft}^{3} / \mathrm{yr}$ of $\mathrm{CH}-\mathrm{TRU}$ wastes and $2,000 \mathrm{ft}^{3} / \mathrm{yr}$ of $\mathrm{RH}-\mathrm{TRU}$ wastes. These receipt rates correspond to approximately 1,200 55-gal drum-equivalents of $\mathrm{CH}-\mathrm{TRU}$ waste per year and $100 \mathrm{FH}-\mathrm{TRU}$ waste canisters per year (assuming $\mathrm{RH}-\mathrm{TRU}$ waste canisters contain the equivalent of four 55-ga] 
drums). The first year that TRU and greater-than-Class C LLW are assumed to be received at the repository is 2003 . Due to uncertainties, the actual TRU waste inventories and repository TRU waste receipt rates may be higher by as, much as a factor of two.

Table 3.4 al so summarizes the principle TRU waste forms that were determined in this survey. As shown, the most common waste forms are solidified 7 iquid wastes and uncompacted metal $1 \mathrm{ic}$, paper, and plastic wastes. Solidification of liquids (such as decontamination solutions and filter sludges) represents the minimur treatment for these wastes because free liquids are not acceptable at low-level waste disposal facilities and they are excluded from jisposal at WIPP (Westinghouse 1984) and civilian repositories (10 CFR 60). Therefore, these wastes must be immobilized in some manner regardless of where they are disposed of. Metallic, paper, and plastic wastes from most producers have been essentially untreated because the volumes were smali and in most cases did not warrant volume reduction. One exception is the west Valley Demonstration Project where the plan is to compact the waste. Reiatively large quantities of TRU wastes produced a the MRS facility are also planned to be compacted. However, these facilities are unique in that relatively large quantities of TRU waste will be generated. Another exception is that some metallic wastes are cut and sectioned to fit with in waste containers and sometimes are aiso sprayed with a fixative to prevent the spread of contamination. Incineration of combustible wastes is unlikely to be an economic alternative because of the small waste quantities and the high costs of incineration and support facilities. Repository performance consicerations might, however, result in requirements to eliminate any organic components by incineration. Based on this preliminary analysis, the most common TRU waste forms were determined to be cemented wastes for liquids which have been dewatered (or evaporated), and metallic, paper, and plastic wastes which have not been treated either to reduce volumes or to alter the waste form matrix. 
TRU isotopic contents and radiation ievels of the TRU wastes are also shown on Table 3.4. The TRU isotopic contents and radiation leveis are shown to be relatively low for most of the TRU wastes. It is shown that only a small amount of the wastes contain a medium or high TRU isotope content (ciefined in this study as having concentrations greater than $1000 \mathrm{nCi} / \mathrm{g}$ ). Oniy the Battelle Columbus wastes have a potentially high TRU content. These wastes were generated from spent fuel rod cutting operations and some may ultimateiy be classified as high-level wastes (HLW). General Electric Co. has some spent fue? wastes that were not inciuded on the table because it was concluded that they should be classified as HLW (intact fuel rods, fragments, etc.). Approximately 70 percent of the TRU wastes will be contact-handled (i.e., they will have surface dose rates 1 ess than $200 \mathrm{mili}$ irem/hr). The remaining 30 percent are projected to be remote-handled.

The most widely used $\mathrm{CH}-\mathrm{TRU}$ waste primary container is the 55-gal steel drum. This applies to both high- and low-dose-rate TRU wastes. 0ther primary containers included 30- and 80-gal drums, two sizes of steel boxes, and two sizes of sealed aluminum tubes. The larger primary containers are typically used for applications tn which large pieces of discarded equipment are stored. The use of larger containers minimizes the amount of cutting and sectioning that are needed to place the equipment within the container. The aluminum tubes were used for special purposes and do not contain a large portion of the TRU wastes. These wastes could be placed in 55-gal drums or other primary containers, if necessary for disposal. It appears that 55-gal drums will continue to be used extensively in the future and should be considered the reference TRU waste primary contalner for repository design bases. However, the repository should also include provisions for receiving large contaniers on an as-needed basis.

Fifty-five-gallon drums are also used extensively for RH-TRU wastes. However, since RH-TRU wastes will be handled at the repository using the same equipment and facilities as those used for spent fuel, similar waste containers should be used (i.e., a monolithic steel canister that is handled from the top). One potential concept is to design an RH-TRU waste canister that can be used to 
overpack three to four 55-gal drums. Use of an RH-TRU waste container similar to the defense RH-TRU waste canister (Rockwell 1984), except about $3 \mathrm{ft} 1 \mathrm{onger}$ and designed to hoio four rather than three 55-gal drums, was here. This canister would measure approximately $25 \mathrm{in}$. in diameter and $13 \mathrm{ft} 1 \mathrm{ong}$, exciuding the lifting pintle.

Table 3.5 presents a summary of the TRU waste quantities and in terms of numbers of waste containers rather than waste volumes. The estimated spl it between $\mathrm{RH}-$ and $\mathrm{CH}-\mathrm{TRU}$ wastes is also presented. 
TABLE 3.5. Summary of RH- and CH-TRU Waste Quantities, Numbers of Waste Containers ( $\mathrm{ft}$ )

\begin{tabular}{|c|c|c|c|c|c|c|}
\hline & Special & Quantities & Current & Inventory & Annual & Additions \\
\hline Waste Producer & $\mathrm{CH}-\mathrm{TRU}$ & RH-TRU & $\mathrm{CH}-\mathrm{TRU}$ & RH-TRU & $\mathrm{CH}-\mathrm{TRU}$ & $\mathrm{RH}-\mathrm{TRU}$ \\
\hline Nuclear Power Plants & 520 & 15 & 910 & 25 & $65-120$ & $2-4$ \\
\hline $\begin{array}{l}\text { West Valley Demonstration } \\
\text { Project }\end{array}$ & 5,150 & 1,300 & $-\infty$ & $-\cdots$ & -- & --- \\
\hline $\begin{array}{l}\text { Fuel Fabrication Plant } \\
\text { D \& D Programs }\end{array}$ & 3,430 & $-\cdots$ & -- & $-\infty$ & -- & -- \\
\hline $\begin{array}{l}\text { Dry Rod Consolidation } \\
\text { Facility }\end{array}$ & $-\cdots$ & -- & -- & --- & 440 & 290 \\
\hline $\begin{array}{l}\text { Commercial Research } \\
\text { Laboratories }\end{array}$ & -- & --- & -- & 20 & -- & 1 \\
\hline $\begin{array}{l}\text { Other Industrial Users } \\
\text { of TRU Isotopes }\end{array}$ & 120 & -- & 150 & -- & $60-200$ & -- \\
\hline TOTALS & 9,220 & 1,320 & 1,060 & 45 & $\begin{array}{l}130-320 \\
(570-760)\end{array}$ & $\begin{array}{c}2-4 \\
(300)\end{array}$ \\
\hline
\end{tabular}

(a) CH-TRU Waste quantities are given in units of 55 -gal drum-equivalents.

(b) RH-TRU waste quantities are givenn in units of RH-TRU waste-container-equivalents. The RH-TRU waste container is assumed to hold four 55-gal drums.

(c) Numbers in parentheses indicate the annual TRU waste generation rate if at-MRS or if atMRS or at-repository consolfdation is implemented. 
•. 


\subsection{BRQPOSER COMMERCIAL_TRANSURANIC WASTE ACCEPTANCE AND_CERTIEICATION REOUIREMENTS FOR DISPOSAL IN A GEOLOGIC REPOSITORY}

The overall performance of a geologic repository is determined by the properties of the waste form, the system of engineered barriers placed around waste forms, and the geotechnical parameters that describe the properties of the geologic media or host rock. The repository must establish TRU waste acceptance requirements to ensure that the performance of the geologic isolation system (which includes the waste form, engineered barriers, and geologic media) is adequate to protect the health and safety of the general public and waste handling personnel. The requirements developed in this study apply specifically to the waste form and the primary or innermost waste canister for acceptance at a repository. Depending on the reposjtory media, an additional overpack and possibly some backfill material may be required at the repository to provide resistance to long-term corrosion and 1 ithostatic pressures. Haste acceptance requirements are established for both RH- and CH-TRU wastes that are generated without spent fuel reprocessing (1.e., a once-through fuel cycle is assumed -see Section 3.0). In some cases, these requirements are the same for both $\mathrm{RH}-$ and $\mathrm{CH}-\mathrm{TRU}$ wastes. This report al so suggests ways in which waste producers could potentially certify that their wastes meet each of the waste acceptance requirements. A description of the approach used to devel op these requirements as well as discussions of each specific waste acceptance requirement follows. Part of the effort to develop proposed waste acceptance requirements was sponsored by the DOE Office of Nuclear Energy (NE) through the Commercial Nuclear Waste Treatment Program at PNL.

In the foljowing section, the term "canister" refers to the primary or innermost container for TRU wastes. It is assumed that overpacking or assembly of the final waste disposal package, if required, will be performed at the repository. Thus, one can say that wastes will be delivered to the repository in "canisters" and will eventually be prepared and emplaced in the repository in a "waste package." If no overpack is added to the waste canister, the 
"waste package" and "waste canister" refer to the same component. If overpacking is required, the "waste package" will include the waste canister, overpack container, and any other components placed around the canister.

\subsection{APPROACH AND BASES}

The approach to establishing the proposed TRU waste acceptance requirements, as 111 ustrated in Figure 4.1 , for the repository consisted of: 1) defining several areas in which acceptance requirements should be established, 2) preparing a set of draft requirements as agreed to by the team, 3 ) circulating the draft requirements to interested indiviouals within PNL for review and comment, and 4) incorporating the comments into the final proposed requirement. The next step was to develop a list of technical areas in which waste acceptance requirements were needed to adequately protect the health and safety of the pubiic and waste-handling personnel. This list was compiled primarily from the waste acceptance requirements developed by Westinghouse (1984), ONW (1983), Oversby (1984) and Ranklev et. a1.(a) The technical areas were then categorized as either waste form requirements or packaged waste requirements. The purpose of each requirement was established based on information in the above documents and then, if it appeared to be applicabie to acceptance of commercial TRU wastes at a repository, it was retained for further development. The final 1 ist of technical areas and the purpose for a requirement in each area is presented in Figure 4.2 .

The next several steps consisted of dividing the technical areas into three groups. Each team member was assigned to develop draft requirements for one group. When a draft requirement was completed, it was circulated to the other team members for review and comment. The comments from this review cycle were incorporated into the draft requirement and resubmitted to the team for a final

(a) Randk]ev, E. H. et a1. 1983. Draft Waste Acceptance Requirements for the Basalt Waste Isolation Project. Draft Report, Rockwell Hanford Operations, Richland, Washington. 


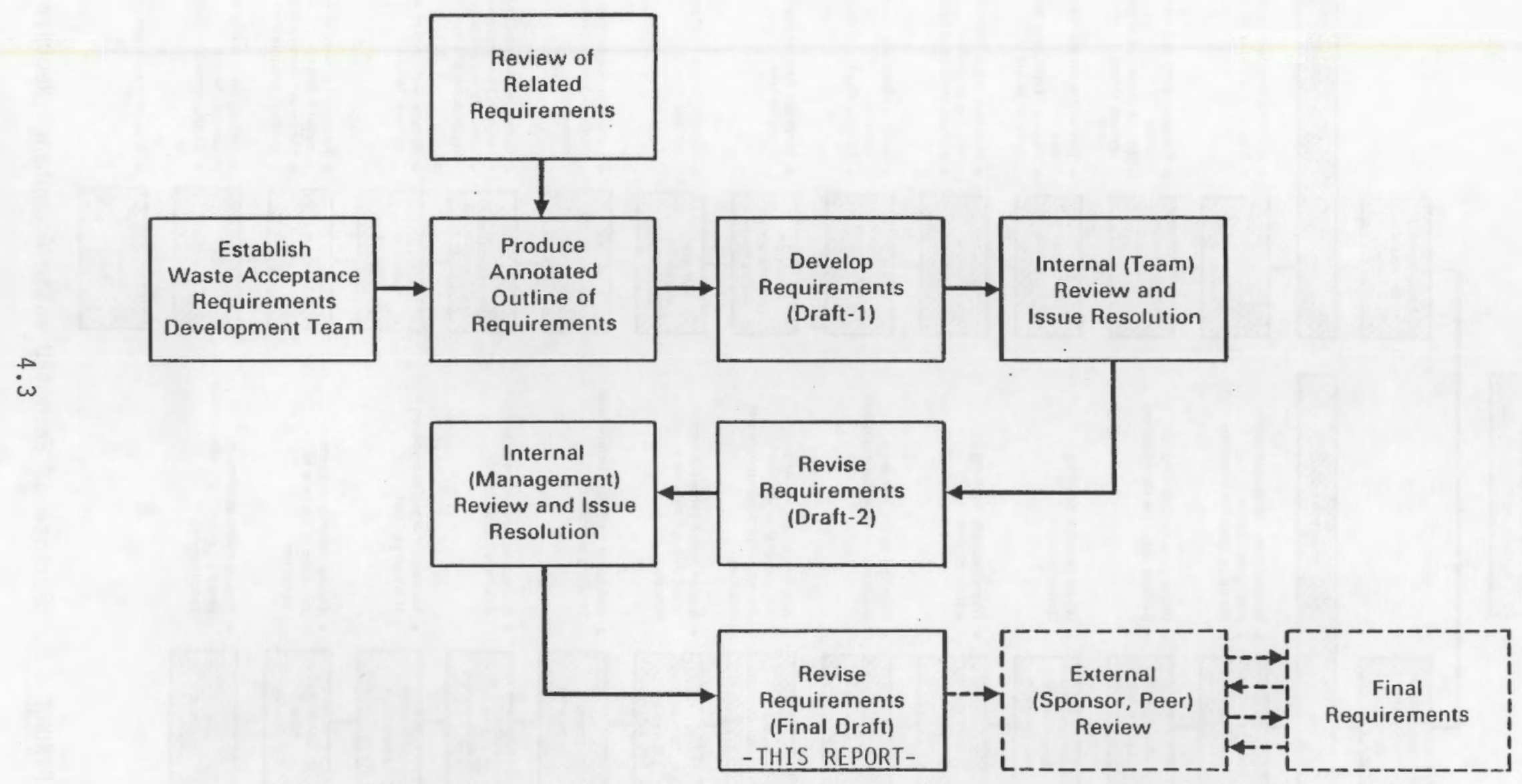

FIGURE 4.1. Illustration of Approach to Develop TRU Waste Acceptance Requirements 


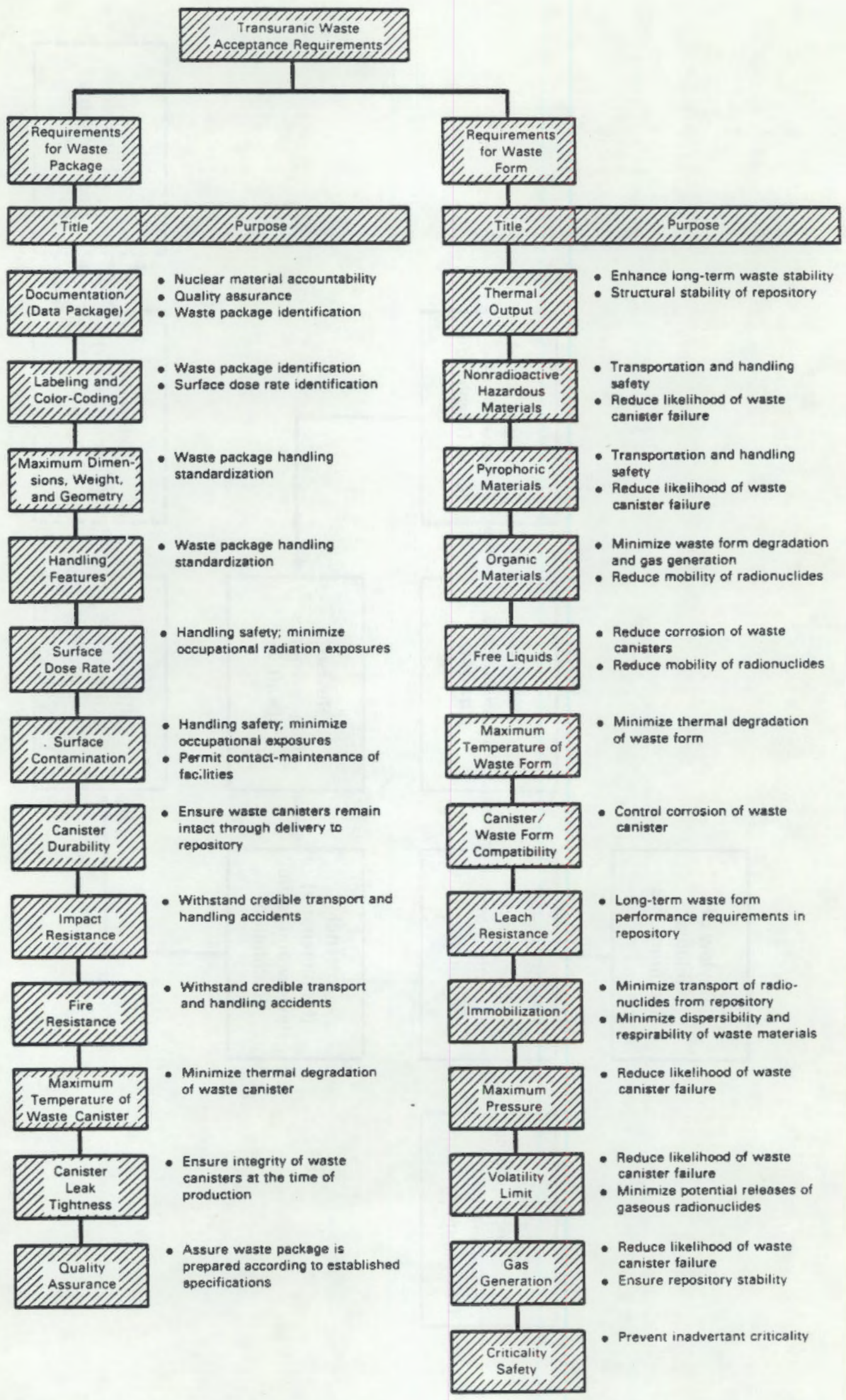

FIGURE 4.2. Purpose of Each TRU Waste Acceptance Requirement 
review to ensure that ali concerns were acidressed. The revised draft requirement was next submitted to an internal PNL management review for further review and comment. The comments from this review cycle were incorporateo into the final proposed requirements which are included in this report. Thus, the requirements that appear in this report have been through two extensive interna] reviews. A draft version of this report was also circulated for an external review. Comments from the external review have been accommodated to the maximum extent possible. However, some of the issues that were raised during the review process can only be addressed by significant additional studies, such as complex thermal analyses of the repositories or experimental programs $w i$ th waste materials. These issues are ioentified, where appropriate, in the report.

The draft waste acceptance requirements were primarily based on published information and on regulations promulgated by the DOT, the NRC, and the EPA. The principal reference used to establish the proposed requirements was the Waste Isolation Pilot Plant Waste Acceptance Criteria (WIPP-WAC) developed by Westinghouse (1984). The WIPP-WAC establishes the requirements for acceptance of defense TRU wastes at the WIPP, which will be the first geologic repository in the U.S. for disposal of radioactive wastes. Waste acceptance requirenents developed by ONWI (1983) and Randkiev et al. (a) for disposal of glass commercial HLW in a salt and basalt repositories, respectively, and by oversby (1984) for disposal of defense $H L W$ and HLW from the West Valley Demonstration Project were also used. These requirements were adapted, where necessary, to adoress the concerns of TRU waste disposal. The statutes that estabi ish the federal regulatory requirements used to develop the proposed specifications are 1 isted below:

- 10 CFR Part 20 - Standards for Protection Adainst Radiatione U.S. Nuclear Reguiatory Commission.

- 10 CFR Part 50- Apeendix B-Quality Assurance Criteria for Nuclear Power Plants and Fuel Reprecessing Plants, U.S. Nuclear Regulatory Commission.

(a) Randklev, E. H, et a1. 1983. See page 4.3. 
- 10 CFR Part 60 - Disposal of High-Lexel Radioactive Wastes in Geologic Repositories, Jechnical Criteria, Final Rule, U.S. Nuclear Regulatory Commission, Federal Register Vol. 48, No. 120, June 21, 1983.

- 10 CFR 70 - Domestic Licensing of Special_Nuclear Materiale U.S. Nuclear Regulatory Comission.

- 10 CFR Part 71 - Packaging of Radjoactive Material for Iransport_and Iransportation of Radjoactive Material Under Certain Condition. U.S. Nuclear Regulatory Commission.

- 10 CFR 960 - Nuclear Haste Poljcy Act of 1982; General Guidelines for the Recommendation of Sites for the Nuclear Waste Repositories Final siting guidelines, Federal Register Vol. 49, No. 136, December 6, 1984.

- 10 CFR 961 - Standard Contract for Djsposal of Spent Nuclear Fuel and High-Level Radioactive Waste U.S. Department of Energy.

- 49 CFR Part 173 - Shippers-General Requirements for Shipments_and Packaginose U.S. Department of Transportation.

- 40 CFR Part 191 - Environmental Standards for Management and Disoosal of Spent Nuclear Fuel, High-Level and Iransuranic_Radioactive Hastes, U.S. Environmental Protection Agency, Final Rule, Eederal Register Vol. 50 No. 182, September 19, 1985.

Suggested riethods for vaste froducers to certify that their wastes meet these acceptance requirements were alsc ceveloped. Most of this information was based on efforts in the defense TRU waste program to certify FH- and $\mathrm{CH}-\mathrm{TRU}$ wastes for disposal at the WIPP. It is assumed that al1 waste producers will be required to perform a detailed characterization of the quantities and properties of the TRU wastes generated at their facilities. This waste characterization will include assessments of the chemical, physical, and radioiogical properties of each distinctly separate waste form that will te froduced. The detailed characterization must also describe any treatment processes that will be used, 
the effects of treatment on the waste form and waste canister, and the properties of the treated waste form. Waste producers will then be required to describe the controls that will be used to ensure that their wastes meet all of the acceptance requirements. Collectively, this information can be calied a "Waste Certification Plan" (see Appendix B).

The next section of this report describes and discusses the proposed requirements in each of the technical areas shown on Figure 4.2. The format for these requirements includes sections for a statement of the requirement, a discussion of the objectives and bases of the requirement, and a section on suggested procedures waste producers can use to certify that their wastes meet each requitrement ("Assuring Compliance"). TRU waste acceptance and certification requirements for packaged TRU wastes are presented in Section 4.2.1 to 4.2.11 and for waste forms are presented in Sections 4.3.1 to 4.3.12.

\subsection{EROPOSED PACKAGED WASTE ACCEPTANCE REQUIREMENTS}

The proposed requirements established for acceptance of packaged TRL wastes at a repository are discussed in this section.

\subsubsection{Documentation}

Requirement

Complete documentation shall precede delivery to the repository by a minimum of 60 days, shall aiso accompany the shipment of nuclear waste materials, and shall provide the following information pertaining to each waste package.

- identification nuriber of waste package

- dated certification statement that the waste form and container meets applicabie repository acceptance requirements and regulatory requirements

- name of waste producer (origin of waste materials)

- date of packaging 
- prior storage time

- description and quantity of contents (remote- or contact-handied, physical description of waste form, etc.

- assay information, including fissije material content, total alpha curies, and quantities of individual radionuclides

- container description

- description of unusual operating conditions experienced during waste production

- thermal output level (method and date of determination)

- package weight

- maximum surface dose rate

- proposed shipment date (documents that precede shipment)

- actual shipment date and carrier

- items of non-compilance with acceptance specifications; an additional agreement with DOE regarding acceptance of non-standard wastes is required

- completed DOE/NRC Form 741 (Nuclear Material Transaction Report)

- any other data routinely required or provided by transportation operations.

\section{Basis for Requirement}

It is assumed that parameters important to the design and safety (both near- and iong-term safety) of the repository must be known and documented. Strict inventory controls, such as those required for wastes to be shipped to WIPP, will be needed to ensure that technical specifications related to handling and emplacement of wastes will not be violated. These specifications will presumably be established during the licensing process and will be developed based on consigeration of near-term transportation and handing safety and long-term repository performance. Also, these data as well as inventory and emplacement records must be avaitable if it becomes necessary to retrieve the wastes. 
Documentation is necessary to satisfy NRC requirements for nuclear material accountability and quality assurance requirements in 10 CFR 50 for traceability as well as to conform to written procedures for control of quality. For example, assay information on the radionuclides present in each waste container is needed for inventory control as well as to demonstrate that the allowable release limits specified by the NRC and EPA during the licensing process will not be exceeded. Rationale presented jater for the Labeling and Color-Coding requirements address the need for package identification. Guidance for the subjects to be included in such documentation is presented in the standard contract for spent fuel acceptance from utilities by DOE (10 CFR 961). The need for such documentation for TRU wastes can be made, by inference, to these format requirements. The applicable section, 10 CFR 961, Article VI A2(a), makes the following statement:

"Purchaser shall provide to DOE a detailed description of the SNF (spent nuclear fuell and/or HLW to be delivered hereunder in the form and content as set forth in Appendix $F$, annexed hereto and made a part thereof. Purchaser shall promptly advise DOE of any changes in said SNF and/or HLW as soon as they become known to the purchaser."

Appendix $F$ in 10 CFR 961 indicates the type of details needed and a requirement that this information is provided to the DOE by the waste producer no later than 60 days before the scheduled transportation date. An additiona? copy of the data package must accompany the shipment.

Documentation needs stated in this criteria are also based on a number of sources of proposed criteria within the waste management program (ONWI 1983 , Oversby 1984, Randklev et al.(a) and Ross et al. (b)) which are applicable acceptance conditions throughout the waste management system.

(a) Randklev, E. H. et al. 1983. See page 4.3 .

(b) Ross, W. A. et al. 1984. Draft Acceptability Specifications for Disposal of High-Level Waste Solfdified as Borosiljicate_Glass. Draft Report, Pacific Northwest Laboratory, Richland, Washington. 
Assuring Compliance

A data package with the requested information or a completed DOE form will be developed for the presentation of the information in a standardized format. The producer w111 be required to certify that the data package is correct.

\subsubsection{Labeling and Coler Coding}

Requirement

The waste package shall be 1 abeled in code with characters at least $8.75 \mathrm{~cm}$ in dimension and $17 \mathrm{~mm}$ in thickness, that contrast with their surroundings, to unfquely identify the contained waste and provide a means of relating it to the records supplied prior to the arrival of the waste. The character sequence shall signify the type of waste, the waste producer, and a unique waste package identification number.

The waste package shall be consistently coior-coded with $2-i n$. wide bands around its diameter or width, to identify the surface dose rate and waste form. An example of a color-coding scheme is as follows: Single bands for CHTRU: <10 mRem/hr (yel10w), 10-50 mRern/hr (orange), and 50-200 mRem/hr (red); double bands for RHTRU: <10 Rem/hr (red/yellow), 10-40 Rem/hr (red/orange), 40-100 Rent/hr (red/red) and >100 Rem/hr (purple/purple). The color bands may be painted, etched, affixed by a separate color band, or applied by other suitable means. In addition, a similar band, identifying the primary form of the waste shall be located beneath the dose rate bands. Coding shall be as follows: Cement (black), metallic (blue), and all other (brown).

The label and color code shall not adversely affect the performance of the waste package, shall remain permanently affixed, shall be made of a non-interacting material, and shall have a minimum functional lifetime as specified in the container durability requirement. 


\section{Basis for Labeling Requirement}

This requirement is based on a number of sources within the waste management program (Westinghouse 1984; ONWI 1983, Randklev et a1. (a) and Ross et $a 1 .(b)$ ) and are applicable acceptance conditions throughout the waste management system. Package identification is necessary for material management to assure traceability and satisfy quality assurance requirements. An example of a type of marking that might meet this requirement would be an engraved metal tag permanently or rigidly attached to the external surface of the waste package.

The proposed character size is conservatively large (in comparison with the sizes proposed by others) to provide easy identification by workers and will provide visibility by the eye at $20 \mathrm{ft}$ with vision of no more than $20 / 200$. Vision of $20 / 200$ is defined as that necessary to identify characters $8.75 \mathrm{~cm}$ in dimension with a thickness that subtends an arc of 16 minutes of angle ( $17 \mathrm{~mm}$.) These size specifications provide a conservative basis for relating the character size to the vision necessary for identification.

When HLW regulations are adopted for 10 CFR 961 Appendix D, it is anticipated (by inference to identification and information requirements for spent fuel promuigated in Appendix $E$ of that statute) that identification and other information requirements for $\mathrm{HLW}_{\mathrm{W}}$ will be presented therein. This information should also be applicable (by inference) to TRU wastes. This subject is al ready addressed in 10 CFR Part 60 for HLW, as follows:

"Unique Identification A label or other means of identification shall be provided for each waste package. The identification shall not impair the integrity of the waste package and shall be applied in such a way that the information shall be leoible at least to the end of the period of retriexabjlity. Each waste package icentification shall be consistent with the waste package's permanent written records".

(a) Randklev, E. H. et al. 1983. See page 4.3.

(b) Ross, W. A. et al. 1984. See page 4.9. 
The proposed labeling requirement, except for the character size, is consistent with other proposed labeling requirements.

\section{Basis for Color-Coding Requirement}

To assure appropriate waste handling procedures are followed and occupational radiation hazards to waste handing personnel are minimized, radiation levels of the waste containers must be established. Once the radiation levels of the packages are established and coded, unnecessary reevaluation will be eliminated. Regulations applicable to operators handing these wastes require that the whole body dose to personnel not exceed 1.25 Rer/calender-quarter ( 10 CFR 20) and that radiation exposures meet ALARA requirements. The color-coding system will provide a means for operators to rapidiy identify the highest dose-rate containers and take actions to place these containers in a shielded area (such as placing them behind lower dose rate containers or in a shielded storage rooms.

Since RH-TRU wastes will be handled within shielded areas, WIPP (Westinghouse 1984) did not propose a color-coding requirement for this material. However, for RH-TRU wastes, the color-coded surface dose rate will be useful to estimate personnel exposures during routine operations for planning purposes and for demonstrating and verifying compliance with applicable occupational exposure regulations.

\section{Assurino Compliance}

The 1 abel may be either permanent]y attached, stamped or engraved on the external surfaces of waste containers. Accelerated-wearability testing or historical weather-testing data and radiation-damage estimates may be used to demonstrate compliance with the durability requirement placed on their labeling and color-coding system. Administrative controls will be needed to ensure that the correct labeling and color-coding symbols are placed on waste containers. Waste-handling personnel will be trained to quickly identify the meanings of the labejs and colored bands. 


\subsubsection{Maximum Dimensions, Weight, Geometry}

Requirement

$\mathrm{CH}-\mathrm{TRU}$ wastes shall be packaged within metal drums and boxes; drums must be cylindrical and boxes must be right rectangular. Maximum external dimensions of $\mathrm{CH}$ waste containers shall be 1 imited to $220 \mathrm{~cm}$ long by $140 \mathrm{~cm}$ wide by $140 \mathrm{~cm}$ high ( $87 \mathrm{in.} \times 55 \mathrm{in.} \times 55 \mathrm{in.})$. The maximum weight of $\mathrm{CH}$ waste packages shall be 1 imited to $5,000 \mathrm{~kg}(11,000 \mathrm{lbs})$. Waste packages exceeding these limits will be accepted only with the prior approval of the repository operators.

RH-TRU wastes shall be packaged within cyindrical metal canisters. External dimensions of the canisters shall be less than $66 \mathrm{~cm} 00$ by $450 \mathrm{~cm}$ long (26 in. $\mathrm{OD} \times 180 \mathrm{in.}$ iong). The maximum weight of $\mathrm{RH}-\mathrm{TRU}$ canisters shall be $6,000 \mathrm{~kg}(13,2001 \mathrm{bs})$.

\section{Basis for Requirement}

The purpose of these requirements is to ensure that waste producers and/or packagers produce waste canisters and/or packages that are compatible with the repository receiving and handing facilities. $\mathrm{CH}$ wastes will be handled at the repository facilities using forklift equipment (both above- and below-ground facilities). Forklift equipment will be used at the repository to unload the waste packages from transportation packagings, moving thern to and from lag storage, load them onto the hoisting system, and during underground emplacement operations. Thus, waste packages must be compatibie with the lifting attachments provided for the forklift equipment. To facilitate stacking of the waste pakages in the storage or disposal rooms, drums must be right cylindrical and boxes must be right rectangular. Odd-shaped canisters must be overpacked in cylindrical orums or rectangular boxes to assure stacking stability. Small canisters, such as 1 - and 5-gal paint cans and 30-gal drums must also be overpacked in one of the standardized TRU waste primary canisters. 
The most commonly-used $\mathrm{CH}$-waste canister is the 55-gal drum. Other sizes of drums, including 30- and 80-galion drums, have also been used extensively. Current plans call for 55-gal drums to be tanded together in "six-pack" configurations to increase handling efficiency. Boxes are currently being designed and tested; a number of sizes are currently being consiciered. Development of standardized $\mathrm{CH}$-waste canisters and/or packages would increase handling efficiency at MRS and repository facilities, reduce problems with stack instability, and possibly improve storage efficiency. It would be ideal from the standpoint of the repository if oniy one size of drum and one size of box were allowed. However, due to the diverse nature and sizes of the wastes and the many potential sources, it would be inconvenient (and potentially expensive) to waste producers if only one size of drum and one size of box were allowed. Therefore, it is assumed that $\mathrm{CH}-\mathrm{TRU}$ wastes may be packaged in 30-gal and 80-gal drums if necessary, but they would have to be overpacked in the standard 55-gal drum or metal box to accommodate the repository's waste handing systems.

The maximurn allowable dimensions and weights of waste canisters was obtained from DOE (1983) and from reviews of repository and MRS facility designs. The review indicated that the designs of waste handing facilities are not far enough along to provide fim details on sizes and capacities of waste handiing equipment. A review of the conceptual MRS facility design indicated that $\mathrm{CH}$ waste boxes up to $2.2 \mathrm{~m} \times 1.4 \mathrm{~m} \times 1.4 \mathrm{~m}$ would be acceptable. This corresponds to Box $C$ as shown in DOE (1983). The maximum allowable weight was $5,000 \mathrm{~kg}(11,000$ 1bs.). This box could al so be used to overpack six 55-gal drums, if necessary.

RH-TRU waste containers will be handled in hot cells by cranes and rericte manipulator systems. The designs of containers, handling facilities, and interim storage or disposal systems must be coordinated to ensure no mismatches occur. The thermomechanical properties of the host rock and the thermal loadings of RH-TRU waste containers determine, for example, the designs of repository emplacement rooms (e.g., borehole spacing). The thermal loadings 
are, in turn, determined by the heat generation rate of the waste form and the size of the canister. As a result, the design of the emplacement room is a function of the size of the canister (or vice versa).

Designs of waste packages for repository disposal are based on placing one or more overpacks around a canistered waste form. Therefore, the waste generator must use a canister design that is compatible with the systen of overpacks to be placed around it at the repository. The canister must also be compatible with the handling and storage system at the potential MRS facility. A review of waste package conceptual designs in Westinghouse (1982, 1983b, and 1983 c) indicate that the largest waste canister consijered was $61 \mathrm{~cm}$ (24 in.) 00 by $450 \mathrm{~cm}$ (177 in.) long. Therefore, the RH-TRU waste canisters used by waste producers should approximate these limits. This is also consistent with the designs of MRS facility handling and storage systems. The defense RH-TRU waste canister described in Section 3.4 will be slightly larger in diameter ( 26 in. vs. 24 in.) to accommodate four 55-gal orums. This should be considered in the design of the repository's Rfi-waste handling systems.

\section{Assuring Compliance}

As discussed above, the designs of the MRS facility, repository, and waste containers should be coordinated. Additional research is needed to establish the most cost-effective canister design based on the handling capabilities and thermal limits of the disposal system. After this is done, all waste producers shoula use canisters of the established size.

The waste canisters will be received by waste producers from vendors. Administrative controls and control of purchase orders is all that is deemed necessary to ensure compliance with this specification. The control of purchase orders, including surveillance of vendors and their suppliers, will be performed. All waste canisters will be inspected and measured at the source or upon receipt at the waste producers' facilities. The surveillance procedures 
and results as well as the results of inspections of the waste canisters will be documented. These procedures should ensure that waste canisters obtained from vendors meet the applicable specification.

\subsubsection{Handling Features}

Requirement

$\mathrm{CH}-\mathrm{TRU}$ waste packages shall be provided with cleats, offsets, chines, detents, or skids to facilitate their handling with forklift equipment. These features should not interfere with stacking or close-packing of the waste packages and should be designed with a minimum safety factor of three.

RH-TRU waste packages shall be provided with a standardized axial lifting pintle whose design has been approved by the receiving facility and the waste producer. The lifting pintle should be designed with a minimum safety factor of three.

\section{Basis for_Requirement}

Most $\mathrm{CH}-\mathrm{TRU}$ wastes have historically been placed in 55-gal steel arums. This practice is expected to continue in the future. To increase their handling efficiency, drums may be banded together in "six-pack" configurations. In addition to drums, various sizes of steel boxes will be used because they can accomodate larger sized objects (e.g., faijed equipment) and because of their increased stacking efficiency. It is planned that these wastes will be handied using conventional forklift equipment. Standard forkifft trucks equipped with special handling attachments for orums, six-packs, or boxes will be used to handle the waste packages. This does not appear to be significantly different than the current practices at most waste generating sites.

Current emplacement pians at WIPP are to stack $\mathrm{CH}-\mathrm{TRU}$ waste packages in disposal rooms in up to three-high, close-packed arrays. Therefore, the waste packages should not have handling features that woula interfere with stacking, 
such as a lifting pintle or other device that protrudes above the top of the container. In addition, waste packages should not have handing features that protrude from their sioes (e.g., handles or excessively large chines). This would interfere with placing waste pacages against themselves in a close-packed array. The handing features should be designed with a minimum safety factor of three, based on transportation requirements in 49 CFR 173.411 .

Remote-handled wastes must be handled when they are within specially designed shielded hot cells, transfer casks, or transportation casks. This equipment will only handle standardized waste packages because of difficulties in repetetively changing connectors and handling attachments (e.g., handling attachments on cranes) in a remote environment. Remote-handled waste facilities will be designed to handle the waste packages in a vertical orientation; also, conceptual designs of transfer casks and transportation casks typically incorporate top-loading features. Thus the canisters and/or packages must be designed to be lifted from the top. This has been accomplished in the past through incoporation of an axialmifting pintle. The iifting pintle should be of a standardized design that is used throughout the waste management system (i.e., waste generators, MRS and repository facilities). This standardization would eliminate the need for several different lifting attachments for remote-handled waste canisters and packages at these facilities. Packages for al1 types of remote-handled wastes, inciuding spent fuel, HLW, FH-TRU, and spent fuel consolfation wastes, should incorporate the same design of lifting pintle. Overpack containers should also incorporate a standarúdesign lifting pintie. Coordination of the designs of the waste package and the designs of the waste handling systems (i.e., at the PRS facility and repository) should be undertaken to ensure that no mismatches occur.

\section{Assuring Compliance}

It is recommended that $D O E$ issue detailed interface specifications regarding lifting attachments and waste package handling features to ensure their compatibility with all facility designs; i.e., they should specify

\subsection{7}


standard or uniform designs. Alternatively, waste producers may generate their own designs which would then be subject to review and approval by the DOE. At this time, these specifications have not been developed. Once the specifications are developed, it will be the responsibility of the DOE to ensure that standard-design primary waste canisters and waste packages are used that are compatible with all parts of the waste management system.

Waste producers are anticipated to obtain pre-fabricated waste canisters from qualified vendors. Administrative controls and inspections of the vendors and their products are needed to ensure these criteria are met. The waste producers will perform surveillance audits and will visualiy inspect each waste canister. The inspections may be performed at the vendor's facility or at the waste generator's facility. The results of the surveillance audits and inspections shall be documented.

\subsubsection{Surface Dose Rate}

\section{Requirement}

$\mathrm{CH}-\mathrm{TRU}$ waste packages shall have a maximum surface dose rate at any point no greater than $200 \mathrm{mRem} / \mathrm{hr}$. CH-TRU waste packages with surface dose rates greater than $10 \mathrm{mRem} / \mathrm{hr}$ shall be color-coded. Waste packages with a neutron emission rate that produces a dose rate greater than $50 \mathrm{mRem} / \mathrm{hr}$ shall be so noted in the data packages.

PH-TRU waste packages shall have a maximurn surface dose rate at any point no greater than $1 \times 10^{5}$ Rem/hr for gamma radiation and a maximum neutron emission rate of $6 \times 10^{8}$ neutrons/sec.

\section{Basjs for Requirement}

Current designs of $\mathrm{CH}-\mathrm{TRU}$ waste handling, storage, and disposal systems for the repository (and MRS facility) are primarily warehouse-type, large throughput systems. These facilities are designed to receive over-the-road transport 
packagings, unload waste canisters from the packagings, and temporarily store waste canisters until they are transferred to longer-term interim storage or disposal facilities. The $\mathrm{CH}-\mathrm{TRU}$ waste handling personnel will use standard forklift equipment (in some cases, shielding on the forktruck may be provided) and special handling devices to $1 \mathrm{ift}$ and move the CH-TRU waste packages. The radiation doses received by these persons must be less than the allowable 1.25 Rem/calender-quarter whole-body dose specifled in 10 CFR 20 . The WIPP defensewaste disposal facility (Westinghouse 1984), the tuff commerciai repository (Dennis et al. 1984), and possibly the commercial repositories in salt and basalt are using onem fifth of this value as their design objective.

$\mathrm{CH}-\mathrm{TRU}$ wastes are defined as those TRU waste materials that are packaged in such a way that their surface dose rate is not greater than $200 \mathrm{mRem} / \mathrm{hr}$ (Westinghouse 1984). This definition also establishes the waste acceptance requirement in this area. Even though this is a low dose rate and most CH-TRU waste packages will have surface dose rates much less than this value, the repository or MRS facility operator should attempt to minimize the background radiation level, which will reduce occupational exposures, in the CH-TRU waste handling facilities. This is being done at WIPP by providing a shieided storage area to temporarily store waste packages with surface dose rates between 100 and $200 \mathrm{mRem} / \mathrm{hr}$ and by placing the higher dose rate packages at the rear of disposal rooms so they are shielded by the lower jose rate waste packages in front. These plans will be facilitated by color-coding CH-TRU waste packages that have surface dose rates greater than $10 \mathrm{mRem} / \mathrm{hr}$ (for ease of identification; see also the color-coding requirement). The WIPP-WAC al so requires that waste packages with significant neutron emissions (greater than $50 \mathrm{~m}$ Rerin/hr) will be so noted in the data packages.

The RH-TRU waste acceptance requirement in this area is based on the waste type with the highest surface dose rate expected to be delivered to the repository or MRS facility. This limit is assumed to apply to all types of remote-handled wastes, including spent fuel, spent fuel consolioation wastes, $H L W$, and $\mathrm{RH}-\mathrm{TRU}$ wastes, because these wastes $w i 11$ be handled by the same waste 
handling subsystems. Spent nuclear fuel will be the highest dose rate material received at disposal facilities. If the $\mathrm{PH}-T \mathrm{RU}$ waste handing fac $\$ 1$ ities are largely separate from spent-fuel handing facilities, a lower dose 7 iriit for FH-TRU wastes may be appropriate.

The reference spent fuel waste package conceptual aesigns for salt and tuff include inner canjsters that contain the rods from 6 PHR or 18 BWR assemblies (Westinghouse $1983 \mathrm{~b}$ and $1983 \mathrm{c}$ ). The gamma dose rate at the surface of these canisters is estimated to be approximately $1 \times 10^{5} \mathrm{Ren} / \mathrm{hr}$ and a neutron emission rate of approximately $6 \times 10^{8}$ neutrons/sec. These canister capacities are approximately two times the capacities of the inner canister of the reference basalt waste package (Westinghouse 1982) and the design criteria of the conceptual MRS facility (in whtch the consolidated fuel canisters contain the rods from 3 PWR or 7 BWR assemblies). These radiation intensities are based on PWR fuel with an initial uranium content of $0.46 \mathrm{MTU}$, a 3.2 wt\% enrichment, and exposures of 33,000 MWd/MTU and BWR fuel with an initial uranium content of $0.19 \mathrm{MTU}$, a $2.75 \mathrm{~W}$ enrichment, and exposures of $28,000 \mathrm{MW} / \mathrm{MTU}$. The assemblies are assumed to be 10 years out of reactor. These gamma and neutron radiation intensities represent a preliminary acceptance requirentent; they are subject to change when results of detailed analyses of the waste management system determine the most cost-effective configuration for spent fue?. In addition, consideration must be given in the future to higher exposure fuel which significantly increases radiation intensities and heat generation rates in comparison to lawer exposure fuel at equivalent cooling times. However, these intensities are representative approximations of the upper current design basis for repository and MRS waste handing faciities.

\section{Assuring Compliance}

The waste producer will be required to certify that the surface dose rates of their waste canisters are below the acceptable limits. This can be accomplished by a combination of administrative controls and non-cestructive tests. Adninistrative controls will track the contents of each canister as it 
proceeds through the waste producer's facility, and will also identify the surface dose rate of the canister on inventory check lists. Surface dose rate tieasurements wirl al so be taken prior to the release of each waste canister from the packaging facility. The purpose of these measurements will be to demonstrate compliance with the above criteria, to obtain the information needed for the data packages, and to facilitate color-coding of $\mathrm{CH}-\mathrm{TRU}$ waste packages with surface dose rates greater than $10 \mathrm{mRem} / \mathrm{hr}$. Measurement equipment must be maintained in accordance with an approved calibration and maintenance plan.

\subsubsection{Surface Contamination}

\section{Requirement}

The ievel of radioactive contamination on the external surfaces of both RH-TRU and $\mathrm{CH}-\mathrm{TRU}$ waste canisters shall be kept as low as practical but shall not exceed 220 disintegrations/ritn per $100 \mathrm{~cm}^{2}$ for alpha activity and 2200 disintegrations/min per $100 \mathrm{~cm}^{2}$ for beta-gamma. The method of measuring surface contamination levels shall be equivalent to the methods presented in 49 CFR 173.443 .

\section{Basis for Requirement}

The external surfaces of waste canisters are often contaminated with low levels of radioactive materials. This radioactive contamination is difficult to avold completely in a waste production or waste handling facility. Therefore, the levels of surface contamination should be kept as low as possible to minimize occupational radiation exposures, to minimize the amount of decontamination of facilities that may be needed and to permit contact (or "hands-on") maintenance of facilities for as long as possible.

A11owable surface contamination levels for shipping canisters for offsite transport are specified by the Department of Transportation (OOT) in 49 CFR 
173.443. The DOT considers these levels are adequate for transportation. However, the WIPP-WAC states that "... for high throughput facilities, such as WIPP, even (the DOT-specified) levels can result in a bulldup of contanination levels within a facility over a period of time that will require significant decontamination efforts" (Westinghouse 1984). As a result, WIPP based their acceptable surface contamination levels on experiences in the Naval nuclear program. These 1 imits were specified at 50 picocuries $/ 100 \mathrm{~cm}^{2}$ for removable alpha contamination and 450 picocuries $100 \mathrm{~cm}^{2}$ for beta-gamma contaminaticn (approximately 2 and $18 \mathrm{dpm} / 100 \mathrm{~cm}^{2}$, respectively). The allowable surface contamination levels specified for commercial TRU waste canisters, however, are based on DOT ifmits because the throughput of the commercial repository is substantially lower than the WIPP throughput rate.

The $\mathrm{CH}-$ TRU waste handling facility designs at WIPP and commerctal repositories are basically large, open-warehouse-type buildings. At WIPP, the CH-TRU waste facilities will handle approximately 70,000 individual waste packages per year (based on a design receipt rate of $500,000 \mathrm{ft}^{3}$ of waste per year). At this throughput, contamination bulldup within the CH-TRU waste handling area could potentialiy be a problem if the DOT surface contamination 1 imits are used (Westinghouse 1984). This throughput rate can be compared with the repository design basis throughput rate for $\mathrm{CH}$-TRU wastes estimated in Section 3.4. The design basis rate was estimated at $10,500 \mathrm{ft} 3 / \mathrm{yr}$ (assuming at-MRS or at-repository consolidation is implemented), which is approximately 2 percent of the WIPP throughput rate. If the wastes are treated to reduce volumes, an even lower fraction of the WiPP capacity would be produced. As a result, contamination buildup within the $\mathrm{CH}$-TRU waste handling facilities will be a substantially smaller problem at the commercial waste storage or disposal facilities. Therefore, the DOT surface contamination limits are consicered adequate for $\mathrm{CH}-\mathrm{TRU}$ waste canisters at the repository and MRS facility.

The RH-TRU waste canisters to be shipped to commercial waste storage or disposal facilities will be handled using hot cells and shielded transfer 
equipment. Thus, surface contamination of these waste canisters is not a direct problem. However, these facilities and components should be kept as "clean" (i.e., free of radioactive contamination) as possible to permit hands-on maintenance as long as practical and to prevent the buildup of contamination within shipping canisters. Therefore, the maximum surface contamination jevels of RH-TRU waste canisters should be kept at or below the DOT limits.

\section{Assuring Comoliance}

The waste producer will be required to measure the removabie (nonfixed) surface contamination levels of waste canisters before they are placed in a shipping canister for offsite transport. Procedures for measuring surface contamination will require sampling of the external surface of the waste canister such as described in 49 CFR 173.443 . These procedures must be documented and the performance of the measurement procedures must be in accordance with an approved Quality Assurance plan. The results of these measurements must al so be documented and the appropriate information must be recorded in each waste canister's data package.

\subsubsection{Canister Durabilitye Leak Tightness, and Compatibility With Waste Form}

\section{Requirement}

Remote-handled and contact-handled TRU waste primary canisters must meet the requirements specified for a Type A package as found in DOT transportation regulations ( 49 CFR 173), both at the time of production and after 110 years in air storage.

\section{Basjs for Requirement}

The purpose of this requirement is to ensure that waste packages renain intact without showing indications of significant degradation (e.g., extensive external corrosion, visible failure of seal or canister, contents spilled). To 
avoid having to repackage or overpack TRU wastes prior to repository disposal, the waste packages shoulo remain intact during maximum potential producer (10 years) and MiRS facility ( 100 years) storage. Both the effects of air storage and any potential corrosion mechanism of the canister materials, including internal corrosion caused by the waste form, must be taken into consiceration when demonstrating compliance with this requirement. These requirements are Iisted and discussed together to avold repetition because they have similar bases. The requirement that the primary waste cotainers meet Type $A$ requirements for 110 years may be reduced in the future after wast management system operating alternative are refined.

In the past, disposal of TRU wastes has been primarily in waste canisters that meet the requirements of the DOT for Type A radioactive material packaging. These canisters, such as the DOT Specification $17 \mathrm{H} 55-\mathrm{gal}$ carbon steel orum, must meet certain minimum requirements for durability and resistance to transportation-imposed environments. Tests for certification of Type A packages include a water spray test, free drop test, compression test, and penetration test (49 CFR 173.465). Most of the more durable Type B transportation canisters (which are required to withstand hypothetical accident conditions) are required to have their contents packaged in Type A canisters. Since most TRU wastes are expected to be transported in Type $B$ canisters because of theí $r$ radionuclice contents, TRU waste canistors must, at a minimum, meet the requirements of a Type A package.

CH-TRU waste canisters are assumed to be provided with a filtered vent in the lids to allow gases generated in the waste canisters to escape. It is assumed that the filtered vent will be designed with an opening that could be mechanically sealed during transport and removed for storage or disposal purposes. RH-TRU wastes are assumed to be welded closed, similar to HLW and spent fuel canisters. However, these canisters are assumed to need only Type $A$ certification from DOT, simflar to $\mathrm{CH}-\mathrm{TRU}$ wastes, because their performance in the repository depends primarily on the system of overpacks and engineered barriers that will be placed around the waste form primary canister in the 
repository. Therefore, since Type A canisters should be sufficiently ieak-tight to meet the needs of transportation and handing, additional leak tightness requirements are not needed. See also the requirement for impact resistance which establishes an allowable leak rate after an RH-TRU waste canister is subjected to a free drop test.

This requirement does not specify that waste canisters must remain intact for any length of time after emplacement at the repository. Eecause they are not designed for long 7 ife in a corrosive environment, standard DOT $17 \mathrm{H} \mathrm{55-gal}$ drums cannot be expected to remain intact in a saturated repository (basa)t and possibly tuff) for long periods of time. This observation is based on the results of a project (Bishoff and Hudson 1979) to retrieve buried TRU wastes at the Idaho National Engineerfing Laboratory (INEL). It was found after exhuming the wastes, which had been buriec in trenches that were inadvertently flooded, that approximately two thirds of the drums were severely breached. Therefore, if a basalt or tuff repository requires waste packages to remain intact for a specified period of time, such as the operational period, it is assumed to be the responsibility of the repository operator to provide this capability. The repository operators could repackage wastes in more durable canisters, such as stainless steel canisters, or alternatively, could place the TRU waste canisters in a high integrity overpack. This should not be a major concern at a sâlt repository because the waste pacages are expected to remair dry.

\section{Assuring Compliance}

Waste producers must present evicience to the DOE that the particular waste canister they pian to use will meet this requirement. Proposed waste canisters that have not already been certified as a Type A package will be tested to show that they meet these requirements. The test results and supportiris analyses niust be subritted to the DOT for review and approval. Testing programs to certify waste canisters must consicer the effects of long-term (110 years) storage in air, including thermaliy-induced and radiation-induced degradation 
of the waste canister materials. The effects of internal corrosion caused by the waste form must also be considered.

Waste producers are anticipated to obtain fabricated waste canisters from qualified vendors. Administrative controis and control of purchase orders is all that should be needed to ensure these requirements are met by the asfabricated waste canisters. Surveillance of vendors and their suppliers, including quality assurance inspections, shall be performed by the waste producer. The surveillance procedures and results as well as the results of inspections of waste canisters will be documented.

\subsubsection{Impact Resistance}

\section{Requirement}

CH-TRU waste canisters shall not be breached if dropped a minimum of $2 \mathrm{~m}$ or 2 canister-lengths onto an unyielding surface in the most damaging orientation. Visual inspection of the waste canisters after this orop test shall reveal no evidence of canister breach.

RH-TRU waste canisters shal1 not be breached if droppeo a minimum of one canister-length onto an unyielding surface. Breach is defined as a release rate that exceeds $10^{-5} \mathrm{~atm}-\mathrm{cc} / \mathrm{sec}$ (based on dry air at $25^{\circ} \mathrm{C}$, with a differential pressure of 1 atm.)

\section{Basjs for Requirement}

The drop test specified for CH-TRU waste is based on conditions expected to be encountered in repository emplacement rooms. The current underground emplacement plans call for stacking CH-TRU waste drums and boxes in three-high arrays (Stinebaugh 1984). Thus, in order for a canister to be placed on the top row, it would have to be 1 ifted approximately $2 \mathrm{~m}$ off the floor of the emplacement room. This is the highest lift the canisters are expected to encounter. This drop height aiso exceeds the drop height specified for a Type $A$ canister ( $1.3 \mathrm{~m}$ ) in DOT regulations (49 CFR 173.465). 
CH-TRU waste canisters can be considered acceptable if they pass the specified drop test without a visible breach. This acceptance criterion was obtained from DOT regulations which state that Type A canisters shall be designed so that "... when subjected to the tests specjfied in section 173.465 or evaluated against these tests by any of the methods authorized by section 173.461(a), the packaging wi11 prevent: (1) loss or dispersal of the radioactive contents; and (2) any significant increase in the radiation levels recorded or calculated at the external surfaces for the condition before each test." Therefore, breach is defined in terms of a gross 105 s of mechanical integrity, rather than in terms of a maximum allowabie leak rate. This acceptance criterion is believed to be adequate for CH-TRU waste canisters and waste packages because they are not expected to be required to maintain radionuclide containment for 300 to 1000 years under repository conditions. Thus, the concern is related to near-term transportation and handling safety rather than long-term performance in the repository (see canister durability requirement). An additional acceptance criterion is presented in the discussion related to immobilization of the TRU waste form (i.e., there are limits on the sizes of particles that can be produced as a result of the impact test).

The drop height specified for RH-TRU wastes is also based on the highest expected lift of canisters during handling operations. The highest lift is approximately one canister-length. This may occur if it is necessary to i ift one canister over another; e.g., when one canister is in lag storage in a vertical position and a second canister must be 1 ifted over it. In most cases, this will not occur because designs of hot cell facilities should provice for recessed $1 \mathrm{ag}$ storage sleeves which protrude only a short distance above the floor of the hot cel1. In other words, most of the length of the lag storage sleeve, and thus, most of the length of the canister, will be located below the floor of the hot cell. As a result, a drop height of two canjster-lengths is considered to be adequate. 
As specified, the RH-TRU waste canisters must not be breached after the drop test. Breach is defined as a release rate in excess of $10^{-5} \mathrm{~atm}-\mathrm{cc} / \mathrm{sec}$ (measured on the basis of dry air at $25^{\circ} \mathrm{C}$, with a differential pressure of $1 \mathrm{~atm}$ ). This is a significantiy more stringent requirement than that imposed on $\mathrm{CH}-$ TRU waste canisters. A more stringent requirement was justified on the basis that RH-TRU wastes contain significantly larger quantities of fission products, such as, Co-60, Sr-90, Ru-106, and Cs-137. Additional research is needed to specify the most appropriate maximum allowable release rate. This release rate would presumably be based on minimizing exposures of operators and the general public to radioactive materials released during potential accicents during transportation and handling operations.

\section{Assuring Compliance}

Waste producers will be required to provide evidence that the waste canisters they plan to use can meet these specifications. In general, the producer $w 111$ be required to produce experimental or analytical results that support the acceptance of their particular canister designs. This may be done by appropriate references to tests and analyses of waste canisters conducted by the DOE. If the canister design is determined to be acceptable by the DOE, then that particular design will be considered acceptable for use. Thereafter, that particular waste canister design will be considered acceptable if it is manufactured wthin appropriate specifications and is undamaged.

The waste producer will be required to verify, by implementation of a quality assurance program, that the waste canisters were fabricated in accordance with their design specifications and within dimensional tolerances. Administrative controls and control of purchase orders, such as inspection and surveillance of vendors, will be necessary to ensure compliance with fabrication specifications. Each waste canister will be inspected at the vendor's facility and/or upon its receipt and after packaging operations at the waste producer's facility. The surveillance procedures and results, as well as the results of inspections of the waste canisters, will be documented. 


\subsubsection{Eire Resistance}

Requirement

$\mathrm{CH}-\mathrm{TRU}$ wastes shall be packaged in noncombustible canisters.

RH-TRU wastes canisters shall be noncombustible and shall have sufficient burst strength to withstand an $800^{\circ} \mathrm{C}$ fire for 15 minutes duration without resulting in a breach.

\section{Basis for Requirement}

There is a low probability that waste canisters will be involved in a petroleum or electrical fire during transport and handing operations. Fires could potentially cause waste canisters to fail due to overpressurization or thermal degradation and could a1so contribute to the dispersal of gaseous or other volatile radionuclides and other contaminated materials from a breached canister. Therefore, criteria in this area are needed to mitigate the effects of potential fires.

In the event of an accidental fire, the RH-TRU waste canister must not act as a means of fire propagation by adding fuel to the fire and must have sufficient burst strength to resist a breach due to overpressurization. NRC transportation regulations (20 CFR 71) require shipping canisters to be capable of withstanding the effects of an $800^{\circ} \mathrm{C}$ fire for 30 minutes without releasing its contents. This particular choice of fire temperature and duration is representative of an extremely low probability but credible transportation accident environment and considers the availability of fuel to sustain the fire and the availability of resources to extinguish it. For transportation fires, this includes conslderation of the proximity to truck and rail fuel tanks. For waste management facilities (and other fixed facilities), however, large quantities of fuel are not expected to be stored in close proximity to waste canisters and fire equipment is more readily available. As a result, the 
hypothetical fire in a fixed facility would not be expected to last as long as a transportation fire. Therefore, it is assumed that the fire resistance specification for RH-TRU waste canisters should reflect a lower duration than a transportation fire. A fire duration of 15 minutes is assumed based on similar specifications for HLW canisters in BMI/ONWI-521 (ONWI 1983).

$\mathrm{CH}-$ TRU wastes are less of a concern because they contain substantially lower amounts of gaseous and other radionuclides. In addition, CH-TRU waste canisters are assumed to be vented and thus, overpressurization during a fire in a disposal room is not expected. However, research is needed to design the most effective vent system that could handle the rapid outgasing that could occur in a severe fire. Also, since untreated combustible materials have been exciuded from the repository (see specification on organic materials), the waste form itself will not be combustible, and thus, if a waste canister were to become breached, only minute amounts of radioactive materials would be released from the canister and subsequentiy dispersed. As a result, no specific hypothetical fire accident test conditions for acceptance of CH-TRU waste canisters will be proposed. However, since the waste canisters must be qualified as a Type $A$ canister under DOT regulations, they must be designed so that containment and shielolng are maintained during transport and storage in a temperature range of $-40^{\circ} \mathrm{C}$ to $70^{\circ} \mathrm{C}(49 \mathrm{CFR} 173.412)$.

WIPP personnel (Westinghouse 1984) examined the capabilities of CH-TRU waste canisters to: 1) function as a fire barrier to prevent the contained wastes from becoming involved in a f1re; and 2) not act as a means of fire propagation by adding fuel to the fire. They performed a number of fire simulations to address these concerns. One conclusion from these studies was that plywood boxes and steel drums failed to function as fire barriers to protect the contained wastes. However, since combustible waste forms have been excluded from the commercial repository, the waste canisters need not function as fire barriers because the wastes presumably have been rendered noncombustible. A further conclusion of the fire studies was that plywood boxes 
actually provide fuel to the fires and, because they have been coated with fibergiass for moisture protection, the protective coating produces a dense toxic smoke. Metallic waste canisters and overpacks will not support combustion or contribute to the formation of toxic fumes.

\section{Assuring Compliance}

The waste producer will be required to demonstrate the capability of RH-TRU waste canisters to satisfy the fire resistance requirement. A related requirement deals with the volatility of the waste form and subsequent pressurization of the waste canister during a fire. Results of tests or calculations to show that these requirements are satisfied shall include the maximum internal pressure and temperature of the canister wall under the specified fire conditions. If a test is conducted, the integrity of the canister shall be verified by a leak test. The leak rate of the canister after the fire test must be at or below the maximum allowable leak rate established by the canister leak tightness requirement. If a calculation is used to verify compliance with the fire resistance specification, the burst strength shall be assumed to be no greater than the yield strength of the canister material at the maximum temperature. The results of these tests and/or caculations must be submitted to the DOE for approval before the canister will be accepted for disposal. Alternatively, DOE may ultimately conduct waste canister acceptance tests and analyses that could be referenced by waste producers in their Waste Certification Plan (see Appendix B).

After approval of a particular waste canister design, administrative controls and inspections of canisters fabricated by qualified vendors are necessary to ensure that this requirement is met. The administrative controls and inspection requirements shall be documented in the waste producer's Waste Certification Plan. 


\subsubsection{Maximum Temperature of Waste Canister}

\section{Requirement}

The maximum surface temperature of waste canisters fabricated of stainless steel should not exceed $375^{\circ} \mathrm{C}$ and those fabricated of carbon steel should not exceed $250^{\circ} \mathrm{C}$, when stored in air.

\section{Basis for Requirement}

Thermal cegradation of waste canisters could potentially cause the canisters to fait. The purpose of this requirement is to establish a maximum temperature limit to minimize the effects of themal degradation of waste canister materials.

Several materials have been proposed for fabrication of waste canisters. The two most likely materials are two steel alloy types: austenitic stainless steels and carbon steels. In general, austenitic steels are used for high-temperature applications (above $430^{\circ} \mathrm{C}$ or $800^{\circ} \mathrm{F}$ ). Thus, they would be most appropriate for high-activity wastes, such as spent fuel, HLW and RH-TRU waste. Carbon steels are less desirable for high temperature applications because they have poor "creep" resistance at temperatures above $315^{\circ} \mathrm{C}$. Creep is a materlal jeformation process that occurs when materlals are subjected to Toads at relatively high temperatures for a long period of time and ultimately results in their failure. Austenitic stainiess steels are nore resistant to high temperature environments than carbon steels.

The surface temperature limit for stainless steel waste canisters is $375^{\circ} \mathrm{C}$ based on information developed by Jenks (1977) and information in DOE/EIS-0046F (DOE 1980). At higher temperatures (greater than $400^{\circ} \mathrm{C}$ ) ouring long-term storage in afr, austenitic stainless steels exhibit an increased susceptibllity to stress corrosion cracking. A conservative temperature $1 \mathrm{imit}$ of $250^{\circ} \mathrm{C}$ for carbon steels was chosen based on information in Rahn et a\}. (1984). 
The stainless steels are also more resistant to corrosion. It may be that TRU waste canisters, including 55-ga7 drums and various sizes of boxes and cylindrical canjsters, will ultimately have to be fabricated of stainless steel for the repository to meet certain minimum performance objectives. This would significantly increase the costs of the waste management system because stainless steels are also, in general, more expensive than carbon steels. Additional research is needed to determine whether or not all TRU waste canisters will be required to be fabricated of stainless steel.

\section{Assuring Compliance}

It will be necessary for waste producers to certify that the maximum temperature at the surface of their waste canisters does not exceed the limits specified above. Waste producers will need to characterize in detail the wastes they plan to ship to disposal, including an assessment of the maximum expected surface temperature. This can be done either by measuring loaded actual waste canisters or by estimating the heat generation rate of the contained waste and calculating the maximum surface temperature. The heat generation rate is determined by the concentrations of radionuclides in the waste form. If the calculated or measured temperature is less than the specified maximum temperature, administrative controls are all that are necessary to assure compliance with this requirement. Administrative controls such as establishing maximum quantities of certain high-heat-generating radionuclides (e.g., Sr-90, C5-137, and Pu-238) per canister to control the heat generation rate will be needed. Measurements of the surface temperature of actual radioactive production waste canisters is not necessary, although it coulo be done on a sampling basis if the administrative controls are not adequate. The sampling frequency, temperature measurement procedures, and results of actual measurements would have to be documented. If the calculated or measured surface temperatures exceed the requirements, the wastes would have to be aged for a specified period of time to allow for radionuclide decay. The aging period could be calculated based on the concentrations of radionuclioes in the waste form and their decay characteristics. 


\section{2 .11 Quality Assurance}

\section{Requirement}

The waste producer shall implement a OA program with respect to waste package production that is based on the criteria in 10 CFR 50, Appendix 8 . This requirement applies to all waste types and all potential waste producers, including the MRS facility.

\section{Basis for Requirement}

The purpose of quality assurance (QA) is to provide adequate confidence that the subsystems and components of a facility (such as an MRS facility or repository) perform satisfactorily in service. The performance of the waste forms and waste canisters is an important aspect of the interim storage and/or geologic isolation system. QA must therefore be applied to the production of the waste forms and waste canisters since they are considered a subsystem of the geologic repository.

NRC reguiations in 10 CFR 60 indicate that the repository must implement a QA program based on the criteria of 10 CFR 50. Appendix $B$. In addition, 10 CFR 72. "Licensing Requirements for the Storage of Spent Nuclear Fuel in an Independent Spent Fuel Storage Installation," also requires a QA program based on the criteria of 10 CFR 50. Appendix B. (These regulations are currently being revised to establish 1984.) Consequently, the waste producer will al so be required to implement a $Q A$ program for all aspects of waste production based on on the requifements of 10 CFR 50 Appendix $B$.

In many cases, the waste producer must perform tests and analyses on simulated or production waste forms and waste canisters to demonstrate compliance with a particular specification. The waste producer will also be required to establish approprlate administrative controls and inspection programs that assure compliance with the acceptance requirements. After 
approval of the waste form/canister and QA Program has been given by the receiving facility (and the NRC), the waste producer's QA program will be relied upon to assure compliance; i.e., additional testing and analyses of production wastes and waste canisters are not needed except perhaps on a sampling basis. The waste producers $w 111$ be required to certify that their waste forms have been produced and waste canisters have been fabricated within the tolerances specified by the receiving facility. This certification procedure will be facil itated by the waste producer's $Q A$ program and associated quality control measures.

\section{Assurine Compliance}

The DOE will be responsible for establishing a $Q A$ program for the repository which complies with the requirements of 10 CFR 50 Appendix $B$. Waste producers will be responsible for establishing a OA program that addresses all aspects of their waste production and processing activities. The NRC is the agency responsible for approving the QA programs. In all cases, the applicant (the waste producer or DOE) must prepare a description of the $Q A$ program to be applied to the design, fabrication, construction, and testing of the structures, systems, and components of the factlity. The applicant must al so include information related to managerial and administrative controls to be used to assure safe operation. The description of the QA program shall inciude a discussion of how the applicable requirements of 10 CFR 50 Appendix 8 are satisfied. Approval of the $\mathrm{QA}$ program by the NRC will constitute compliance with this requirement.

\subsection{PROPOSED WASTE FORM ACCEPTANCE REQUIREMENTS}

The proposed requirements established for acceptance of TRU waste forms at a repository are discussed in this section. 


\subsubsection{Ihermal Qutput}

\section{Requirement}

Individual $\mathrm{CH}-\mathrm{TRU}$ waste canisters in which the average thermal output exceeds the following values shall have the themal power recorded in the data package. The values of thermal power are specific for the repository media and are $1.8 \mathrm{~W} / \mathrm{ft}^{3}\left(64 \mathrm{w} / \mathrm{m}^{3}\right), 2.4 \mathrm{w} / \mathrm{ft}^{3}\left(85 \mathrm{~W} / \mathrm{m}^{3}\right)$, and $1.3 \mathrm{~W} / \mathrm{ft}^{3}$

$\left(46 \mathrm{~W} / \mathrm{m}^{3}\right.$ ), for repositories located in salt, basalt, and tuff, respectiveiy.

The thermal output of Individual RH-TRU waste canisters shall not exceed the limits to be determined for each media. (This criterion is dependent upon repository design.)

\section{Basis for Requirement}

The thermal output or heat generation rate of waste canisters or packages strongly influences the designs of interim storage and disposal systems. For example, the themal loading of waste packages and the thermomechanical properties of the repository host rock determine the minimum allowable package spacing in repository emplacement rooms that would not cause serious degradation of the host rock. Thermal loadings must also be controlled to ensure that the temperatures reached in the waste form do not cause serious degradation of its capabilities to act as a containment barrier. (Maximum temperatures of the various waste forms are discussed in a separate criterion.) In addition, the heat generation rates must be controlied to ensure that temperatures reached in other components of the interim storage or disposa) system (including other waste package components such as the backfill or overpack) do not significantly reduce their performance capabilities.

Heat generation rates of waste packages help to determine the maximum temperatures of the near-field repository host rock (or interim storage system at the MRS facility), waste form, canister, overpack, and backfill. Heat 
generation rates are, in turn, determined by the properties of the waste form and the size of the canister.

Thermal analyses of repositories located in salt, basalt, and tuff have determined areal thermal loading limits ( $k W$ of heat generating waste per acre) that will not produce unacceptabie impacts on the host rock or surrounding environment. These local limits are to be determined.

The emplacement density of $\mathrm{CH}-\mathrm{TRU}$ waste in a commercial repository is approximately $80,000 \mathrm{ft}^{3}$ of waste per acre (based on stacking of waste packages g-ft. high in disposal rooms and assuming a 50 percent stacking efficiency). Using the $75 \mathrm{kH} /$ acre limit for salt (Westinghouse 1984), this would allow an average heat generation rate of $1.8 \mathrm{~W} / \mathrm{ft}^{3}$ or $13.2 \mathrm{~W}$ per 55-gal drum. For basalt and tuff, these 1 imits are $2.4 \mathrm{~W} / \mathrm{ft}^{3}$ ( $\left.16.8 \mathrm{~W} / \mathrm{drum}\right)$ and $1.3 \mathrm{~W} / \mathrm{ft}^{3}$ (8.8 $\left.\mathrm{W} / \mathrm{drum}\right)$, respectively, based on loca? thermal limits of $190 \mathrm{~kW} / \mathrm{acre}$ for basalt and 100kW/acre for tuff (Westinghouse $1983 \mathrm{a}$ ).

Contact-handled wastes generally have low heat generation rates and will not approach the local areal thermal loading limits. Thus, it will not be necessary to piace stringent controls on thermal power limits of CH-TRU wastes. However, some inventory control of high heat generating wastes would be prudent to prevent localized hot spots in waste storage or disposal arrays. This would be facilitated by requiring waste producers to record in the data packages heat generation rates of $\mathrm{CH}$-TRU waste canisters that exceed the thermal fower 1 imits calcuiated above.

The emplacement plans for RH-TRU wastes are substantially different among repository media. In addition, the designs of interim storage concepts and the repository emplacement rooms have not been finalized. Since RH-TRU wastes will be handled similarly to HLW and spent fuel, the same thermal limits will apply. Thermal analyses of al1 three potential geologic media have been performed to support waste package design activities (Westinghouse 1982, 1983b, and 1983c). Emplacement room design parameters, such as borehole (or canister) spacing and 
the dimensions of the rooms, were input to the thermal analyses. These parameters are different among repository media because the heat transfer capabilities of each type of rock are different. Therefore, different therma? 1 imits are needed for wastes to be emplaced in each media.

As discussed previously, the design of the storage rooms is a function of the heat generation rate of the waste packages (or vice versa). For example, PH-TRU wastes with high heat generation rates must be placed further apart than waste with low heat generation rates. Since neither the designs of emplacenent rooms nor waste packages have been finalized, a range of potential heat generation rates and room designs for each media are possible. More detailed thermal analyses cannot be perfomed until either the waste package design or the emplacement plan is finalized.

\section{Assuring Cempliance}

Administrative controls would be the primary method of assuring compliance with these criteria. It is assumed that the waste producers will track and analyze waste streams, including sampling and laboratory analysis. Accurate inventories of significant radionuclides contained in each waste stream will be maintained. The heat generation rates can be calculated from the radionuclide inventory. The backup and verification method for the radionuclige inventory are radionuclide assay techniques. Active (differential die-away and electron linear accelerator) and passive neutron assay combined with passive gamma spectroscopy can identify all TRU radionuclides, most fission products, and reveal information about the waste form matrix (Caldwell et al. 1983). Alternatively, the heat generaticn rates can be calculated from measured surface temperatures and thermal emissivities. An adaptation of commercial infra-red imaging techniques may be capable of detecting any localized hot-spots in waste canisters. 


\subsubsection{Nonradioactive Hazardous Materiais}

\section{Requirement}

The waste form shall not contain explosives, compressed gases, toxic and other hazardous matertals (as defined in 49 CFR 173) in an amount that would compromise the function or performance of the waste package or the performance objectives of the repository.

\section{Basis for Requirement}

The purpose of this requirement is to prevent the repository from becoming a disposal system for anything but radioactive wastes. Requirements related to a number of nonradioactive materials are considered separately in this document (see requirements concerning pyrophoric and organic materials, gas generation and maximum pressure) because of considerations unfque to each. Discussions concerning these materials are not repeated here.

The WIPP-WAC (Westinghouse 1984) do not allow explosives or compressed gases and in addition, no hazardous materlals are acceptable unless they exist as co-contaminants with transuranics. Adding hazardous materials to TRU waste streams for disposal is not allowed. This is primarily because WIPP (and the commercial repository) will not be designed to handle these materials. Their presence in the waste form in significant quantities could also contribute to waste canister or waste package degradation, are likely to increase the probability of failure, and may enhance the mobility of radionuclides in the repository. It is expected that such hazardous nonradioactive materials will be disposed of, where possible, by other means (e.g., other types of hazardous waste dumps such as shaliow land burial).

Similar criteria (1isted below) are also specified in 10 CFR 60.135 for HLW and by inference are applicable throughout the waste management system: 
"Packages for HLW shall be designed so that the in situ chemical, physical and nuclear properties of the waste package and its interactions with the emplacement environment do not compromise the function of the waste packages..."

"The waste package shall not contain explostves... or chemically reactive materials in an amount that could compromise the ... performance objectives."

"The design criteria shall include, but not be limited to consideration of the following factors: oxidation/reduction reactions, ... fire and explosion hazards ..."

\section{Assuring Compliance}

Administrative controls will provide training to operators to prevent loading of nonradioactive hazardous materials into waste canisters.

The waste producer will be required to provide the chemical composition for nonradioactive materials in terms of weight percent for all components greater than 0.5 percent, as suggested in criteria developed at NNWI (Oversby I984) for such materials in HLW. These data can be used to demonstrate that hazardous materials are not in the waste form or in the free volume of the canister.

Operators 111 be required to $f 111$ in a waste form checklist that describes the contents of each waste canister. The waste producer would then be required to certify that the actual radioactive production wastes do not contain these nonradioactive hazardous materials. X-ray real-time radiography may be used to demonstrate that these materials are not present in actual production wastes. Aiternatively, waste producers could open and visually inspect a representative sample of waste canisters to demonstrate that this requirement is met.

\subsubsection{Eyrophoric Materials}

\section{Requjrement}

The maximum amount of non-fixed radioactive pyrophoric materials that may be present within a waste canister is 1 wty. Any larger quantities shall be 
dispersed in a homogeneous manner and fixed throughout the waste canister to el iminate the potential hazaro associated with self-ignition.

\section{Basis for Requirement}

Pyrophoric materials (as defined in 49 CFR 173 Subpart E) are those that may ignite spontaneously under amblent conditions of shipment or storage. This could contribute to a breach of the waste canister and/or waste package followed by release of contained radioactivity and exposure of operating personnel and the public to radionuclides in the waste form.

Zirconium from fuel hulls is one of the primary concerns for initiating fires from materials associated with spent fuel and its hardware but will not be a significant concern uniess or until reprocessing is utilized. Pyrophoric metallic fines from plutonium and uranium, if present, are also of concern. Metallic pyrophoric fines must be prevented from concentrating into pockets in the waste canister and becoming a fire hazard.

Regulatory guidance can be inferred throughout the waste management system from current HLW design criteria presented in 10 CFR 60.135 b, that states:

\footnotetext{
"The waste package will not contain...pyrophoric materials or chenicaliy reactive materials in an amount that could compromise the ability of the underground facility to contribute to waste isolation or the ability of the geoiogic repository to satisfy the performance objectives."
}

Recent1y, the WIPP-WAC (Westinghouse 1984) established a conservative 1 imit of 1 percent for pyrophoric forms of radionuclide metals distrituted in a moderately homogeneous manner in the TRU waste form. This was based on studies at Rocky Flats Plant (RFP 1974) that indicated that a thoroughly dispersed oistribution of 3 percent pyrophoric plutonium in plutonium oxide would not self-ignite. This 1 imit is assumed to be applicable to commercial TRU wastes. 


\section{Assuring Compljance}

It is assumed that waste producers will be required to characterize in detaij the physical and chemical properties of the wastes they pian to dispose of in a repository. Presumably, this woulo include an assessment of the concentrations of radioactive contaminated pyrophoric materials expected to be generated. If a waste producer detemines there would be less than 1 wt\% of pyrophoric materials in the wastes, treatment to render the pyrophorics nonhazardous would not be needed. Administrative controls would then be needed to ensure that operators do not load more than 1 wt\% pyrophorics into waste canisters and that the pyrophorics are oistributed as homogeneously as practical. If pyrophoric materials are determined to be present in the wastes in excess of $1 \mathrm{wt} \%$, the waste producer must define and describe in detail an appropriate waste treatment method and provide evidence that the proposed treatment method will render the materials nonpyrophoric. This could be done either by oxidizing the pyrophorlcs to a nonpyrophoric form (e.g., convert Pu metal to $P($ oxide), or fixation of the pyrophoric materials into a cement or other suitable waste matrix. Administrative controls, process monitoring, and feed sample analyses would then be used to demonstrate that the pyrophoric content of the waste form is with in acceptable limits. Demonstration of the waste treatment process using nonradioactive simulated wastes and subsequent destructive evaluation of the waste form may be used as evidence that he treatment process adequately mitigates the hazaros of pyrophoric materials. Destructive evaluation of actual radioactive waste forms should not be needed.

\subsubsection{Qrganic Materials}

\section{Requirement}

Organic $\mathrm{CH}-\mathrm{TRU}$ and $\mathrm{RH}-\mathrm{TRU}$ waste materials shall be treated so they are rendered noncombustible and so they will not generate gases or chelating agents in concentrations that would compromise the integrity of the waste form or waste canister or the performance objectives of the repository. All waste materials will be packaged in noncombustible canisters. 


\section{Basis for Requirement}

A large fraction of the existing and future TRU wastes contains or will contain substantial amounts of organic materials (e.g., paper, wood, piastics, rubber). The concerns regarding disposal of contam Inated organic materials are:

- organic materials are combustible and thus present a potential fire hazard

- organic materials could contribute to or cause the formation of explosive concentrations of gases such as hydrogen and methane within waste canisters, or cause the formation of sufficient quantities of gases which could overpressurize the waste canister

- organic materials could contribute to the formation of complexes, colloias, polymers, etc., that could enhance waste form leach rates andor radionuclide mobility.

These issues are addressed below.

The first issue addresses the combustibility of organic materials which may result in a fire hazard during transportation, handling, interim storage, or disposal operations. The combustibility issue was addressed by NRC in 10 CFR 60 which states that combustible wastes shall be reduced to a noncombustible form unless it can be shown that a fire will not compronise the integrity of other waste packages, safety-related systems or components, or the geologic isolation system.

Organic materials, besides being combustible, are subject to thermal, radiolytic, corrosive, and bacterial degradation that coulo contritute to significant gas generation within waste packages. A requirement related to gas generation is discussed in a separate section.

Waste form and canister degradation have al so been show to produce chemical compounds whose interactions with the waste can reduce radionuclide sorption (or increase migration) in the geologic media (Westinghouse 1984). 
Thus, organic materials coula contribute to the formation of chelating agents, which are chemical compounds that enhance the mobility of radionuciides. These agents are used in the nuclear industry as decontamination agents to remove radioactive materials from contaminated equipment and materials. Research is needed to determine the types and amounts of chelating agents that woulc be produced during long-term isolation and their effects on the performance of the waste package/repository system. Due to this uncertainty, it would be prudent at this time to exclude untreated organic materials from the repository. This is consistent wih the conclusions presented in NUREG/CR-2333 Vol. 2 (NRC 1982). The authors of that document also pointed out that 1) combustible organic materials will almost certainly not meet a numerical performance criterion applied to the reposttory, 2) no credit can be given to the as-generated TRU waste form as an engineered barrier, and 3) processing techniques are well established (e.g., incineration and acid digestion). Because of the difficulty of proving that there are no interactions between organic materials and other wastes in the repository, it may be necessary to incinerate these wastes. However, this criterion is not consistent with the WIPP-WAC in which the overall conclusion was that combustible wastes would be acceptable at WIPP if they are packaged in noncombustible canisters (Westinghouse 1984).

The cost impact of eliminating combustible materials is not anticipated to be prohibitive. According to Mckee at a). (1984), provioing for incineration of combustible wastes is estimated to increase the cost of the waste management systern (including treatment, transportation, and repository costs) by approximately 5 percent when compared with compaction of the wastes (based on treatment of reprocessing wastes). However, it was also determined that incineration of combustible wastes produces a net systen cost savings when compared with a minimum treatrient (i.e., packaging oniy) option. This conclusion is also consistent with the conclusions of Ross et al. (1985). Since incineration (with subsequent incorporation of the ash in cement) woulo result in a more stable waste form and does not produce a net system cost increase, this waste treatment concept is more favorable than no treatment or minimum treatment. Another potential method of eliminating combustibles would be to 
shred combustible wastes and incorporate the shredded wastes in cement. This would produce a more stable waste form than the minimum treatment option and is Tikely to be less expensive than incineration. Based on this discussion, it is concluded that eliminating combustibles from the repository wili produce a more stable waste form but will not result in major increases in waste management system costs.

\section{Assuring Compliance}

The organic content of TRU waste materials can be certified by a combination of administrative controls, testing of representative samples, and inspection of out going waste canisters by the waste producer. Administrative controls would include instructing operators not to load organic or other combustible materials into waste canisters and requiring preparation of checklists of drum contents at the waste source. OA audits of operators and verification, on a sampling basis, of canister contents with the checklists would be needed to certify that no untreated organics are present. It is noted that the DOE, in addition to the controls discussed above, is planning to inspect defense TRU wastes for organic materials using $X$-ray real-time radiography (RTR) units (see Section 5.0). However, these units are expensive and also require detailed operator training. Thus, it is not iikely that producers of small quantities of TRU wastes could justify he expense of such a unit.

\subsubsection{Eree Liquid}

\section{Requirement}

TRU wastes shall contain no detectable amounts of free 1 iquids that could be drained from the waste canisters or that could compromise the integrity of waste canisters. 


\section{Basis for Requirement}

Free liquios of concern include water, aqueous 501 utions, and organic solvents. The requirements for organic materials are dealt with in a separate criterion where untreated forms of these materials have been determined to be not acceptabie. TRU waste sludges, water and aqueous solutions can provice a source of brine formation. Brines can corrode canister materials, leach the waste form, and produce a mobile fluid that contains radionuclides. This process is a concern because the structural integrity of the canisters and waste packages may be degraded by the liquids during long-term storage. In addition, siudges or these liquids may provide a mechanism for pressure bulldup due to radiolysis and a mechanism for corrosion of waste canisters.

Regulatory gujance for IRU wastes can be inferred throughout the waste management system from current HLW design criteria presented in 10 CFR 60.135b, that states:

"(2)Free liquids. The waste package shall not contain free liquids in an amount that could compromise the ability of the waste package to achieve the performance objectives relating to containment of HLW (because of chemical interactions or formation of pressurized vapor) or result in spillage and spread of contamination in the event of waste package perforation during the period through permanent closure."

This is assumed to be applicable to commercial TRU wastes, also.

\section{Assuring Compliance}

Waste producers will be required to certify that their wastes do not contain free 1 iquids that could be drained from the waste canister. Detailed characterization of the physical and chemical properties of the as-generated wastes will be needed, including an assessment of the free liquid content. If an excessive amount of free liquids are expected to be introduced into waste 
canisters, the wastes must be treated. A solidification compound could be added to the wastes to act as a water "getter" materiai to ensure the absence of free water. The solidification compound should be added to waste canisters in amounts that would ensure there is 50 percent more solidification compound than is required to absorb the amount of water in the waste canister. Administrative controls during loading of the waste canister will assure the proper addition of this material to each canister. X-ray real-time-radiography coufd also be used to demonstrate that free liquids are not present in the waste canister.

\subsubsection{Maximum Jemperature of Waste Form}

\section{Requirements}

The maximum temperature of a cenent waste form shall not exceed $100^{\circ} \mathrm{C}$.

Other waste forms, such as metals, ceramics, and glass, shall not exceed temperatures that cause the waste canister temperature limit to be exceedeo (see Section $4.2 \cdot 10)$.

\section{Basis for Requirement}

The purpose of this requirement is to help ensure the mechanical integrity and radionuclide release properties of TRU waste forms.

The properties of cements currently proposed for TRU waste encapsulation are degraded after prolonged exposure to temperatures in excess of $100^{\circ} \mathrm{C}$ (Lea 1971, Nevilie 1981). After such exposure, water trapped in pores and capillarjes within the cement is lost. This loss leads to significant microcracking of the waste form which would increase the dispersibility of the waste. The limit identifled in the requirement was chosen to ensure that cement waste forms remain intact and are not significantly aitered by the encapsulated waste's neat generation. The temperature limit specified for other waste forms is substantially below any temperatures where any significant 
physical changes are likely to occur. For example, the limit suggested for borosilicate $\mathrm{HLW}$ glass is $500^{\circ} \mathrm{C}$. (a)

\section{Assuring Compliance}

The composition of a waste form could be determined from process measurements, particularly from feed analyses. These analyses would include determinations of the amounts and types of heat generating radionuclides. With this information, the heat generation rate of the waste form could be determined. With a knowledge of the therma? properties of the waste form/package the maximum expected temperature of the waste form could be calculated. The waste producer would then be required to certify that the radionuclide content of the wastes produced do not exceed the 1 inits at which an unacceptable temperature of the waste form would be reached. This could be demonstrated by measuring the radionuclide content of each waste canister prior to releasing it for transport. Radionuclide content could be estimated by measuring the surface dose rate and applying conversion factors for each isotope that are determined by the waste producer or by processing loaded waste canisters through gamma and neutron assay systems.

\subsubsection{Leach_Resistance}

\section{Requirement}

The average release rate of radionuclides from TRU waste forms shall be 1 ess than or equal to one part in 1000 per year as indicated by the slope at 28 days of the MCC-1 leach test (Kuhn, Peters, and Simonsen 1983) performed in deionized water. This requirement does not apply to any radionucilide which is released at a rate less than 0.1 percent of the release rate limit.

\section{Basis for Requirement}

This requirement is needed to ensure that a minimum level of radionuclide containment is provided by the waste form. This is needed in the event of a

\footnotetext{
(a) Ross, W. A. et al. 1984. See page 4.9.
} 
preclosure accident involving a flood in the repository or a severe transportation accident involving a body of water, or in the event of fiooding at the MRS facility. It is also needed to help ensure radionuclióe containment after the waste form is emplaced at the repository. Testing of waste forms, which is implied by this requirement, is not meant to demonstrate a repository-relevant radionuclide release rate. Demonstration of the radionuclioe release that will occur from a repository wili be the responsibility of the DOE.

The release rate exemption for radionuclides with release rates less than 0.1 percent of the release rate 1 imit is based on the similar exemption found in 10 CFR 60.113 .

Release rates of radionuclides can be limited by the solubilities of the radionuciides themselves, by mass transfer resistance in groundwater (e.g., sorption by the host geology) and/or by the rate at which they are leached from the waste form. Solubility and mass transfer resistance will iimit the release rates of most actinides and may other radioisotopes from the waste package (Kuhn, Peters and Simonsen 1983). Such releases will be several orders of magnitude lower than the rate of release due to waste form leaching alone, and should easily meet the NRC radionuclide release limit of less than one part in $10^{5}$ per year (10 CFR 60). The release of some elements, such as Cs, may be limited only by the durability of the waste form. The limit set in this requirement of 1 part in 1000 is based on the performance that could be achieved by cement or borosilicate glass waste forms. Other engineered barriers and the repository's geochemistry will be avallable to further 1 imit the release rate from the repository.

\section{Assuring Compliance}

Testing of doped simulated waste form material will be performed to demonstrate the waste form's leach rate in the MCC-1 test. This testing should be performed with the purpose of qualifying the range of waste form 
compositions, waste loadings, etc. which are anticipated from the process for producing a particular waste form. The task of assuring compliance with this requirement then becomes one of demonstrating that the material produced is with in the range of compositions which has been qualified. This would be done through the use of process measurements such as feed sample analyses.

\subsubsection{Immobilization}

Requirement

The fractions of the waste forms, both as-produced and after the impact test specified elsewhere, being converted to particles less than 200 microns in diameter shall be 1 imited to 15 wty or less for dispersion control and particles less than 10 microns in diameter shall be 1 imited to $20 \mathrm{Cl}$ of $\mathrm{Pu}-239$ equivalent isotopes or less for control of respirable particulates. These requirements apply to both $\mathrm{RH}-$ and $\mathrm{CH}-\mathrm{TRU}$ wastes.

\section{Basis for Requirement}

There are two principal concerns regarding immobilization of the waste form. These are: 1) long-term radfonuclide mobility enhancenent in the repository and 2) radionuclide dispersibility and inhalation after a waste container is breached during an accident. The first concern is addressed el sewhere (see leach resistance and free 1 iquids requirements) and the latter concern is addressed here.

Radionuclide dispersibility and inhalation hazards exist to the general public and waste handing personnel if finely divided powders or potentialiy airborne waste forms are routinely transported and handled. If a waste container was to become breached, a finely divided waste form could cause widespread contamination. Studies have shown that particles less than 10 microns in diameter pose the greatest hazard of being inhaled and retained in human 1 ungs and particles less than 200 microns in diameter are readily dispersible (ONWI 1983, Hestinghouse 1984). Aithough respirable particles are 
substantially more hazardous than dispersible particles, particles that are readily jispersibie woulo contaminate the immediate vicinity of a breached waste container. This type of event would require decontamination of the area involved and associated occupational radiation exposures and cleanup costs. Therefore, it is desirable to minimize the amounts of respirable and dispersible particles in any waste container.

The amounts of respirable and dispersible particles within any as-produced waste container is assumed to be 1 imited to $20 \mathrm{Ci}$ of Pu-239 equivalent isotopes and $15 \mathrm{wt} \%$, respectively. The former limit is based on NRC transportation regulations in 10 CFR 71.63 which requires that shipments of waste materials that contain more than $20 \mathrm{Ci}$ of Pu-equivalent material must be doubly contained during transport, unless an exemption 15 granted by the NRC. The Federal Register notice that established this requirement (39 FR 20960) stated

"Since the double containment provision compensates for the fact that the plutonium may not be in a 'nonrespirable' form, solid forms of plutonium that are essentially nonrespirable should be exempted from the double containment requirement."

Thus, it is believed that an exemption from the double containment requirement should be pursued for nonrespirable TRU wastes. The $20 \mathrm{Cl} 1$ imit placed on the Pu-equivalent content of respirable particles is based on the proposed definition of the term "essentially nonrespirable" (McClure et al. 1985). The use of the $20 \mathrm{Ci}$ limit is currentiy being proposed by the Transportation Technology Center (TTC) to support the use of a single containment shipping container for transporting test containers to the WIPP. The 15 wtr 1 imit of dispersible particuiates is based on the WIPP-WAC (Westinghouse 1984).

These limits are assumed to apply to the waste form after the drop test specified elsewhere (see impact resistance requirement); i.e., these limits must a] so be met in order for a particular waste form/container configuration to be approved with regard to the impact test requirement. This requirement effectively el iminates finely divided powders and other potentially airborne 
waste forms from the repository (and MRS facility, as well). For exampie, incinerator ash would not be acceptable unless it were immobilized in cement or other suitable material. According to the WIPP-WAC, these limits appear to be achievab1e.

\section{Assuring Compliance}

The waste producer will be required to certify that their waste forms meet the immobilization requirement. The producers will be required to evaluate their wastes and identify any waste materials that coulo potentially be affected by this requirement. If a finely divided powder will be disposed of that will not meet this requirement in its as-generated form, the waste producer will be required to treat the wastes in some manner and provice evidence le.g., the results of tests or analyses) that indicates the waste form/contalner configuration will meet this requirement. The results of the waste source evaluations and any tests or analyses are anticipated to be submitted to the DOE for approval. Once approval is obtained, administrative controls (waste source evaluation), representative sampling of waste streams, nondestructive examinations of the final waste form, or combinations thereof, are necessary to assure compliance. A waste form checklist is a likely method for waste producers to demonstrate that the immobilization requirements are met, particularly for wastes that will be packaged with little or no treatment. The $O A$ representative will be required to make periodic inspections of as-produced wastes to assure the checklists are accurate. Operators will also be instructed not to load finely-divided powders into waste containers that will not be processed through an immobilization system.

If a waste producer determines that some as-generated wastes will not meet the immobilization requirement, the producer will be required to treat the waste stream(s) in such a manner that the requirement will be met. Several options are available for immobilizing the wastes, such as incorporating them into a cement, glass, or ceramic waste matrix. The waste producer will need to select an appropriate treatment process, specify the composition of the treated wastes, 
and certify that the wastes meet the immobilization requirement. Several alternatives for producers of small quantities of TRU wastes to treat their wastes are presented in Section 5.0

\subsubsection{Maximum Pressure}

\section{Requirement}

For 200 years following the fabrication of an RH-TRU waste form, the normaily occurring pressure within the waste-form's primary container shall not exceed 50 percent of the container's inftial burst strength.

\section{Basts for Requirement}

This requirement is needed to ensure that RH-TRU waste canisters do not fail due to overpressurization during storage at the producer's facility, during normal transportation, during MRS storage, and during the repository's operational periad. The 200 year requirement results from assurned maximum storage times of 10 years by the producer and 100 years by the MRS, and a retrievability period of 90 years at the repository.

"Initial burst strength" is specified in the requirement because this strength is not expected to degrade significantiy during long periods of air storage. If containers are not overpacked at the repository, this strength may degrade due to the action of groundwater. In essence, the producer will certify that the containers will not burst due to overpressurization as long as they are kept away from prolonged contact with water.

The pressures which are the subject of this requirement will be generated by radiolysis, degradation of organics in the waste form, and alpha decay. Pressurization of $\mathrm{RH}-\mathrm{TRU}$ and $\mathrm{CH}-\mathrm{TRU}$ waste containers which results from a potential fire accident is discussed in a separate requirement (see Volatility Limit requirement). 
This requirement does not apply to $\mathrm{CH}$-TRU waste packages because it is assumed that these packages will each incorporate a filterec pressure vent for the release of gases (e.g., methane and hydrogen) generated insioe the waste container. This vent witl be incorporated because it will not be economicaity feasible to construct $\mathrm{CH}-\mathrm{TRU}$ waste pakages to withstand the potential pressures that may occur. The vent would be mechanically sealed during transportation to decrease the chance of release in a severe accident and because vented canisters would not meet DOT Type A shipping container requirements. Filtereo venting should be acceptable during storage or disposal as significant amounts of radioactive gasses will not be released by $\mathrm{CH}-\mathrm{TRU}$ wastes. The radioactive gases (e.g., Rn) which would be released and might accumulate at an MRS or repository would be dealt with by the facility's ventilation system.

Filtered venting would probably not be practical for RH-TRU waste containers due to the need to open and close the vent remotely. If this could be accomplished and sealable vents were incorporated in the RH-TRU waste container design, the need for this maximum pressure requirement would be el iminated.

\section{Assuring Compliance}

As mentioned previously, TRU waste producers will be required to perform a detailed assessment of the wastes they plan to ship to a repository. This evaluation should include an assessment of the gas generation potential of the waste form. The pressures that will occur in a container can be determined from 1) gas generation rates calculated for anticipated waste form compositions, 2) anticipateo container leak rates, and 3 ) anticjpated void volume in the canister. This pressure can then be compared to the burst strength of the waste canister.

The burst strength of waste canisters can be determined by calculation or by testing containers of nonradioactive wastes that have experienced the conditions to be expected during processing. Examples of processing woulc 
include, for example, seal welding and, in the case of containers that will contain a glass waste form, an appropriate heat treatment. The burst strength analyses or testing must be documented.

\subsubsection{Velatility Linit}

Requirement

The pressure in a loaded TRU waste canister which is subjected to an $800^{\circ} \mathrm{C}$ fire with a duration of 15 minutes shall not exceed 50 percent of the canister's burst strength.

\section{Basis for Requitrement}

The purpose of this requirement is to ensure that TRU waste canisters remain intact in the event of a fire.

The pressure that will exist in a FH-TRU waste container as a result of an external fire will be caused by the volatilization of waste form material, and from the heating of existing gases within the container. A portion of these existing gases will have resulted from normal gas generation within the waste form (e.g., radiolysis products or He generated by alpha decay).

It has been specified in these requirements that each $\mathrm{CH}$-TRU waste canister will be fitted with a sealable filtered pressure vent rather than be designed to withstand the pressures that will be generated by the waste form (see Maximum Pressure requirement). Therefore, the pressure within a CH-TRU waste canister which results from heating will be caused by the volatilization of waste form material and the heating of void space gases originaliy at atmospheric pressure. During transportation (when a severe fire is more credible) the vent will be sealed and burst strength determinations must take this into account. Fire accidents could, however, occur at other times wen the canister is vented (i.e., the seal is removed). Burst strength determinations, therefore, must also consider the strengith of the fitter and the maximum rate at which it can vent excess pressure. 
Burst strength determinations must also take into account the possibie degradation of $\mathrm{CH}-\mathrm{TR}$ U waste canister strength that may occur during storage at the waste producer's facility (10 years) and storage at an MRS facility. This strength may degrade to the point that the canister would not be able to withstand the pressures generated during the design-basis fire. Overpacking of these canisters may be required at the repository.

\section{Assuring Compliance}

The fallure strength of TRU canisters can be determined by testing of prototype canisters which have experienced the conditions to be expected during processing. This would include, for example, seal welding and, in the case of RH-TRU waste canisters, an appropriate heat treatment (for some waste forms). This would also include the effects of aging during storage by the producer or at an MRS facility.

The pressures that will occur as a result of the design basis fire can be determined from 1) iaboratory data that indicates the amount of material that will be volatilized from the waste form, 2) a predication of the pressure of existing gas in the canister (applies to RH-TRU waste canisters), and 3) estimates or measurements of the void space that will be present in the canister. These anaiyses will presumably determine the maximum allowable quantities of volatile materials that can be loaded into a single waste canister. Aministrative controls and feed analyses will be needed to verify that the composition of production wastes is less than or equal to the specified 1 imits. This process would be facilitated by preparation of a waste form checklist, similar to that shown in Appendix $B$.

\subsubsection{Gas Generation}

\section{Requirement}

No specific requirements are established here. Meeting the waste acceptance requirements for organic materials, maximum pressure, and free liquids will ensure gas generation is not a probiem. 


\section{Basis for Requirement}

Packaged wastes are subject to degradation by several mechanisms, including radiolytic, thermal, corrosive, and bacterial degradation. Degradation of the waste form could potentialiy produce significant quantities of gas. This gas could potentially buildup within waste canisters to a point in which an explosive gas mixture is accumulated or the internal pressure causes the canister to fail. In addition, if significant quantities of gas are liberated from waste canisters or packages, the capabilities of the geologic isolation system may be impaired [e.g., gas buildup in a salt repository coulo potentially pressurize the emplacement rooms and induce fractures in the surrounding rock (Westinghouse 1984)]. The former concerns are related to near-term transportation and waste handling safety whereas the latter concern is related to long-term isolation of the wastes.

A number of studies have been performed to characterize the gas generation problem. According to Westinghouse (1984), bacterial degradation of organic materials and radiolytic degradation are the dominant mechanisms of gas generation. Even using a series of conservative calculations (including estimated gas production rates, organic material contents of waste canisters and gas permeabilities of rock salt), Westinghouse (1984) concluded that pressurization of storage rooms as a result of gas generation was not a concern The National Academy of Science reviewed these calculations and indicated that bacterial degradation could be considered only a minor problem for two reasons: 1) the humidity in emplacement rooms in a salt repository is likely to be too $10 \mathrm{w}$ (less than 60 percent) to support bacterial growth and 2) bacteria] metabolic activity is poisoned by the accumulation of metabolic products (NAS 1984). The NAS also found that pressurization of $\mathrm{CH}$ waste canisters from radiolysis is not likely to be a problem because the canisters (other than seal-welded RH waste canisters) employ a standard mechanical elastomeric seal that is not leak-tight. This has the effect of allowing waste canisters to "breathe" and slowly release the accumulated gases. Furthermore, hydrogen is not expected to build up in waste canisters to explosive concentrations because 
it diffuses rapidly through elastomers. Because of these conditions, the NAS recommended that the restrictions on gas generation indicated in the WIPP-WAC should be relaxed if the humidity in the repository emplacement rooms is below 60 percent. Gas generation is assumed to not be a probiem to the long-term stability of emplacement rooms in tuff and basalt repositories because of the extensive fracturing of the geologic media that is already or will be present. Therefore, even in a high humidity environment (such as would be produced by flooding of the repositoryl, the gases liberated from the waste canisters would not be expected to cause pressurization of the storage rooms.

The gas generation issue is related to the organic content of the waste form and the maximum allowable pressures within waste canisters. Untreated organic materials have been eliminated from the repository, partiy based on uncertainties related to gas generation (see "Organic Materials" requirement), and thus, bacterial cegradation wil] be effectively prevented. A vent system has been proposed for $\mathrm{CH}$ waste canisters that would effectively prevent their overpressurization. However, the vent would probably have to be plugged during transport and handing operations to satisfy requirements for transportation so the potential for gas buildup exists while the plug is installed. This could potentially cause accumulation of explosive gas concentrations due to radiolysis within the waste canisters or shipping canisters. However, the presence of free iquids in waste canisters has been Timited to insignificant amounts that wil? not produce large quantities of gas. In addition, the production of helium by alpha decay was reported to be negiigible (NAS 1984). Therefore, because of restrictions placed on untreated organic materials and free liquios and the incorporation of a vent system in $\mathrm{CH}$ waste canisters, no specific requirements regarding gas generation is proposed.

\section{Assuring Compliance}

No specific requirements are needed to assure compliance. The assurance requirements related to the waste acceptance requirements for organic materials, maximum pressure, and free liquids are assumed to adequately control and/or imit gas generation. 


\title{
4.3 .12 Criticality Safety
}

\section{Requirements}

The average concentration of fissile or fissionable materials (Pu-239 fissile gram equivalents) for any 5 liters of a waste form with a maximum 50 percent void space shall be no greater than:

\author{
$1.9 \mathrm{~g} / \mathrm{L}$ for $\mathrm{PH}$ waste forms \\ $0.95 \mathrm{~g} / \mathrm{L}$ for $\mathrm{CH}$ waste forms packaged in cylindrical canisters, and \\ $0.75 \mathrm{~g} / \mathrm{L}$ for $\mathrm{CH}$ waste forms packaged in boxes.
}

\section{Basis for Requirement}

This type of requirement is needed to ensure that any assembly of waste canisters or waste packages remafns subcritical during storage, transportation, and disposal.

Criticality must be prevented to protect the health and safety of waste handling personnel and the general public. The fissile material concentration 7 imits for $\mathrm{CH}-\mathrm{TRU}$ wastes packaged in cylindrical canisters and RH-TRU wastes are taken from the WIPP-WAC (Westinghouse 1984). The 1 imit for WIPP-WAC CH-TRU wastes in boxes is based on the limit for waste forms packaged in cylindrical canisters (e.g., drums) and a consideration of the greater packing density of boxes compared to cylindrical drums. Both $\mathrm{CH}-\mathrm{TRU}$ and RH-TRU waste limits will result in the same fissile material density per unit of storage volume. These limits were based on criticality analyses that assumed hypothetical "worst-case" $55-$ gai drums containing a homogeneous mixture of $200 \mathrm{~g}$ of Pu-239 and $91 \mathrm{~kg}$ (200 1bs.) of graphite. The analyses are considered to be conservative because: 1) "real" wastes are not homogeneous; 2) no mixture of "real" TRU waste materials can be as effective in moderating neutrons as the graphite; and 3) the concentration of fissile materials in worst-case drums is substantially higher than the concentration in "real" drums of defense TRU waste. These three items are considered applicable to commercially-generated TRU waste. 
The higher fissile material density allowed for RH-TRU waste forms is due to the neutron absorbing fission product content of these waste forms.

\section{Assuring Compliance}

Waste producers will be required to perform an evaluation of the TRU wastes they plan to deliver to a repository, including an assessment of the fissile or fissionable material concentration. If these concentrations are significantly below the specified 1 imits ( 10 percent or less), administrative controls are al) that are deemed necessary to provide evidence of compliance with this requirement. Administrative controls would include instructions to operators not to load certain high-fissile-content materials into waste canisters in large quantities. The high-fissile-contact materials, if present, would be identified during the waste source evaluation. If waste canisters are expected to contain fissile materials in concentrations that represent a significant fraction of the specified 1 imits (greater than 10 percent), waste producers will be required to provide documented evidence that the fissile content of their wastes does not exceed the specified limits. Radionuclide assay data should be presented to show that the fissile content complies with these limits. These data are also required for the data package. 


\subsection{ALIERNATIVE TRU WASTE CERTIEICAJION AND TREATMENT STRAIEGIES}

The results of the IRU waste producer survey indicated that there were a relatively large number of potential sources with only small quantities of TRU wastes. Most of these wastes are not expected to meet the waste acceptance requirements presented in Section 4.0. For exampie, most of the producers indicated they had some organic wastes such as paper, rubber, and clothing that were essentially packaged without treatment. This procedurewill not be allowed for wastes for disposal in a commercial repository because untreated organic materials have been excluded (see Section 4.0 ). Thus, this type of material will require some form of treatment. Also, TRU wastes must recelve a fair amount of nondestructive examination (NDE) and assaying in order to be certified as wastes that meet applicable acceptance requirements. One alternative for determining the acceptability of these wastes for repository disposal is for the producers to certify the wastes themselves. However, most of the potential waste producers are not equipped with facilities to certify wastes as required by the acceptance requirement presented in section 4.0. These types of certification facilities are costly and difficult to justify on a cost-benefit basis for producers of small quantities of IRU wastes. As a result, provisions are needed that will allow small-quantity producers to treat and certify thelr TRU wastes. This section presents several alternatives that would provide these capabilities. These alternatives are illustrated in Figure 5.1.

\subsection{USE OE EXISTING OR PLANNED DOE EACILITIES}

Large volumes of TRU waste are generated annualiy in defense-reiated activities at several DOE sites. Disposal of these wastes is planned in the Waste Isolation Pilot Plant (WIPP) after their retrieval, processing, and/or certification. (These wastes may be certifiable to the WIPP-WAC without opening their containers or may require processing to meet the WIPP criteria.) As a resuit, the DOE is currently developing concepts and constructing facilities to provide waste processing and certification capabilities for defense TRU wastes. 
Alternative

TRU Waste Treatment

and Certification

$$
\text { Strategies }
$$

Commercial

Nuclear Waste

Storage and/or

Disposal System
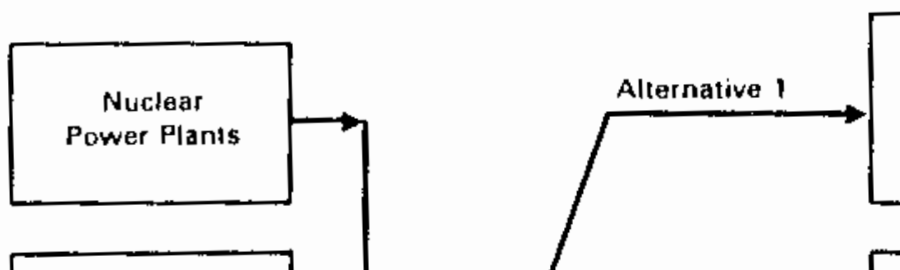

Producer Provides Weste Treatment and Certification Facilities

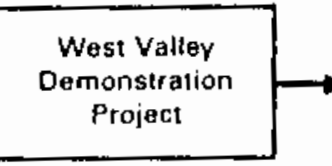
Decontamination
and
Decommissioning
Demonstrations
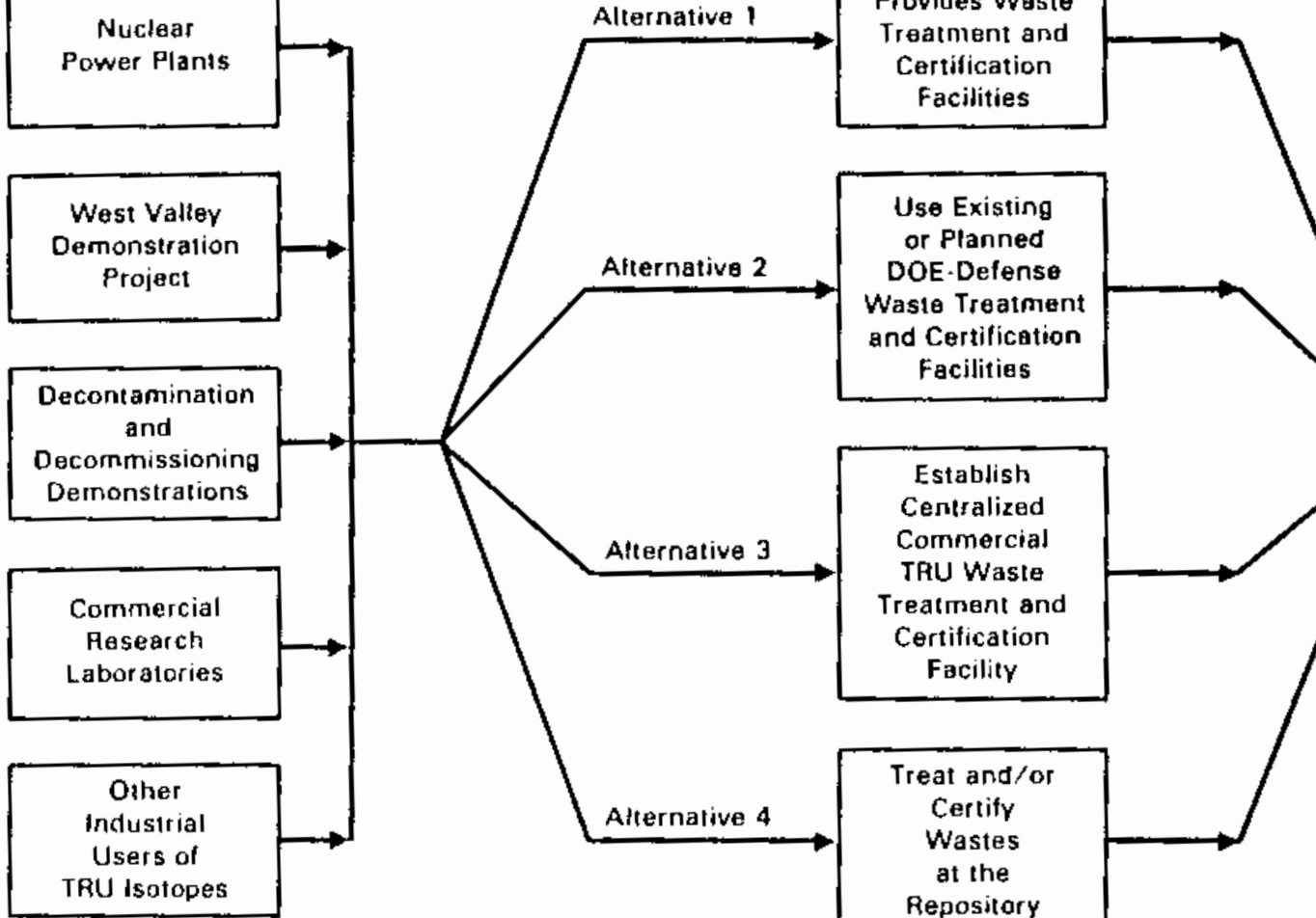

Establish
Ceritralized
Commercial
TRU Waste
Treatment and
Certification
Facility

Federal MAS Facility (Storage) or Aepository (Disposal)

FIGURE 5.1. Il lustration of Four Alternative TRU Waste Treatment and Certification Strategies 
It may be possible for producers of small quantities of commercial TRU wastes to utilize these DOE facilities for processing and/or certifying their wastes. This would eliminate the need for these small-quantity producers to construct and operate costly facilities for this purpose. Some potential DOE facilities that could be used are described below.

\section{Stored Waste Examination Pllot Plant}

The Stored Waste Examination Pilot Plant (SWEPP), to be located at the Idaho National Engineering Laboratory (INEL) is being developed to certify INEL-stored CH-TRU wastes without opening waste containers or processing the wastes. The NDE and assay techniques that wiTl be used in the SWEPP include (McKinley et al. 1983, D'Ambrosía et al. 1984, Clements et a1. 1984):

- active neutron interrogation; determines fissile inventory, including actual quantitfes of $\mathrm{U}-235, \mathrm{U}-233$, and Pu-239

- passive neutron counting; determines alpha activity within containers; alpha activity is used to calculate thermal power and TRU isotopic content

- weighing equipment

- standard health physics instruments and techniques; determines surface radiation dose rate and surface contamination levels

- real-time X-ray radiography (RTR) system; determines content of waste packages from the size, shape, and relative density of contained materials; system will be used to identify free 1iquids, sludges, organic material content, quantity and size distribution of particulates, pyrophoric materfals, explosives and compressed gases, and toxic and corrosive materials; the system produces images of the contents of waste containers that are displayed on TV-type monitors 
- ultrasonic system; performs waste container integrity examinations, including determination that container wall thicknesses are adequate, that the internal surface is corroded or not, and that the 1 ifting and hand ing features are not deteriorated.

These facilities will determine whether or not the IRU wastes can be certified without further processing and will also be used to collect data for the data packages. Construction of the SWEPP facility is scheduled to be completed in FY-1985. Similar facilities are planned for other major defense TRU waste generating sites.

\section{Process Experimental P jlot Plant}

The primary objective of Process Experimental Pilot Plant (PREPP) is to experimentally demonstrate ful1-scale methods for processing the uncertifiable INEL-stored TRU wastes into a form that conforms to the WIPP-WAC (Tait 1984, Clements et a]. 1984). Waste containers that cannot be certified at SWEPP will be sent to PREPP for treatment. Initlally, PREPP will be provided with a Tow-speed shredder system for opening waste contalners and sizing the wastes, a rotary kiln for waste incineration, and a cementing systern for waste immobilization. The off-gases generated by the incineration will be treated through a quencher, Venturi scrubber, moisture eliminator, and HEPA fîters before release from the facility. PREPP is designed to process the uncertifiable IRU wastes at a rate up to $6.4 \mathrm{MT} /$ day. The facility is scheduled to begin 7 imited TRU waste processing experiments in 1 ate 1986.

\section{Waste Receiving and Packaging Facility}

The Waste Receiving and Packaging Facility (WRAP) facility, which is being developed for the Hanford site, is conceptually designed to provide inspection, processing, packaging, and/or certification capabilities for CH-TRU wastes. The INEL experience in the SWEPP and PREPP projects will be factored into the design of the WRAP facility. As a result, the design of the WRAP facility is not as far along as the SWEPP and PREPP facility designs. 
The WRAP facility conceptual design inciudes the following processes and/or equicment:

- size reduction; repackages wastes that are in oversize containers, waste container opening system, dismantiling tools, nibblers, mechanical saws, abrasive saws, electric saws, plasma torches, and/or lasers

- nondestructive assay and evaluation; similar to equipment and processes in SWEPP

- waste shredder/immobilization system; shreds uncertifiable or unacceptable waste forms and, if appropriate, immobilizes shredded material in cement.

The WRAP facility is scheduled to be constructed in the 1990 to 1992 time frame.

RH-TRU Waste Handling Facility

The DOE has recently completed a feasibility study and preliminary design for the RH-TRU Waste Handling Facillty (RWHF) (ORNL 1984). This facility is designed to characterize, process, package, and certify RH-TRU wastes for disposat at WIPP. The facility can process approximately 95 percent of the $\mathrm{RH}$-TRU wastes that are either retrievabiy stored or expected to be generated at Hanford, INEL, Oak Ridge National Laboratory (ORNL), and Los ATamos Nationa? Laboratory (LANL) over the next 10 to 15 years. The facility is designed to process RH TRU wastes on $7 y$ to the extent required to meet the WIPP-WAC (i.e., volume reduction will only be that required for sizing large components so they are compatible with the internal jimensions of RH-TRU waste canisters).

The RWHF is designed to handle and repackage neariy all types of defense RH-TRU wastes. The RWHF will be provided with active and passive neutron interrogation systems, a gamma assay systen, an X-ray RTR systen, weighing equipment, and standard health physics instruments (counters, smear-sample equipment, etc.) to certify that the wastes meet WIPP-WAC requirements. The 
facility will also be provided with a cutting head (a shear or saw) to cut large objects into smaller pieces so they will fit into the RH waste canister. A cement addition system is also provided that will be used, if needed, to meet WIPP-WAC requirements for immobilization, free liquid content, surface dose rate, etc. Currentiy, there are no plans for installing an incinerator system. The RHHF could startup as early as 1991. No site has been selected at this $\operatorname{tin} \theta$.

\section{Savannah River Laberatory}

The Savannah River Laboratory (SFL) is a multi-purpose DOE laboratory. SR is the site of the Defense Waste Processing Facility (DWPF) that will be used to process defense HLW into a borosilicate glass waste form for disposal. An alpha-contaminated Disassembly and Decontamination (AD\&D) Pilot Facility has al so been constructed at the SR (Wobser 1983). The AD\&D facility is designed to demonstrate processing of noncombustible wastes, such as gloveboxes, cabinets, and other large items of contaminated equipment. The facility includes a chemical spray decontamination system (the resulting liquid wastes are planned to be incorporated into glass in the DWPF), remote disassembly and sectioning equipment (for site reduction), and facilities for packaging and certifying the treated wastes for disposal at WIPP. SR researchers al so have developed and tested a full-scale controlled air incinerator for treatment of solid, combustible TRU wastes (Freed 1982). Thus, the SRL appears capable of performing a11 waste treatment and certification activities needed to prepare and certify commercial TRU wastes for disposal.

\section{West Valley Demonstratjon Project}

As discussed previousiy, the West Valiey Demonstration Project (WVDP) wil) generate a large fraction of the commercial TRU wastes expected to be generated. The WVDP includes facilities for volume reduction (compaction) of solid wastes, 
for evaporation of liquid wastes and subsequent immobilization of the concentrates in cement, and for assaying and certification of TRU wastes to meet the WIPP-WAC (Cwynar et al. 1984). The assay systems include a gamma scanner, a passive neutron counting system, direct gamma spectroscoplc and aipha survey equipment, and radiochemical analysis equipment for analyzing samples of liquids prior to immobilization (inciudes liquid scintil)ation counting, gamma spectroscopy, and low-energy photon spectroscopy). The WVDP expects to treat, package, and certify TRU wastes to meet the WIPP-WAC with these facilities. These wastes are anticipated to be disposed of in a commercial repository. Presumably, these facilities would also be capable of performing these operations for commercial TRU wastes, as well.

\section{Rocky flats Plant}

The Rocky Flats Plant (RFP) is a DOE site that generates a large amount of defense TRU wastes. RFP will ship their TRU wastes to WIPP for disposal, and thus, must certify their wastes to meet WIPP-WAC. RFP researchers have designed, constructed, and demonstrated a fluidized bed incinerator for treating a wide variety of TRU contaminated liquid and solid combustible wastes (Melle et a1. 1982, Erfurot 1983, Hickle 1984). The ash produced by the incinerator will presumably be immobilized in cement. RFP is al so developing an Advanced Size Reduction Facility (ASRF) for remotely size reducing and decontaminating gloveboxes and other metallic wastes. Equipment within the ASRF includes remote disassembly tools, a plasma arc torch for cutting glovebox walls, and an electrolytic decontamination system. RFP researchers have al so developed passive nondestructive assay instruments, gamma spectroscopy systems, and orum and crate assaying equipment.

\section{Qak Ridge National_Laboratory}

Oak Ridge National Laboratory (ORNL) is another multi-purpose DOE laboratory that will be disposing of their defense $\mathrm{CH}-$ TRU wastes at the WIPP. Thus, ORNL is also developing the facilitfes and equipment needed to certify their TRU wastes in accordance with the WIPP-WAC. A nondestructive assay system 
for the quantification of TRU isotopes has been in operation at the ORNL since 1982 (Schu1tz et a1. 1985). This facility is referred to as the TRU Waste Drum Assay Facility (TWDAF). The TWDAF inciudes a neutron assay system (NAS) and a segmented gamma scanner (SGS). The SGS provides a list of the gamma-enitting isotopes that are contained in sufficient quantities in the drum. The NAS provides the total mass of fissile materlal and estimates the total TRU content of the drum. This information is currently used to segregate TRU wastes from low-level wastes but could alternately be used to generate data needed to certify TRU wastes for disposal at WIPP.

\subsection{ESTABLISHMENT OF A CENTRALIZED COMMERCIAL WASTE TREATMENI AND CERIIEICATION FACILITY}

This aiternative would establish a single, centralized facility that commercial TRU waste producers could send essentially as-generated wastes and have then treated and/or certified for repository disposal. The purpose of this facjlity would be to receive the wide variety of untreated commercial TRU wastes from the many potentiat sources and produce TRU wastes that are homogeneous (to the maximum practical extent) and that meet applicable waste acceptance requirements. This concept would eliminate the need for organizations with sma11 quantities of TRU wastes to install expensive waste treatment and certification facilities of their own. Such a centralized facility might include waste shredding, compaction, incineration, and immobilization systems, as well as state-of-the-art waste assaying facilities. The facility could be located at the repository, MRS facility, or other suitabie location. More research is needed to determine the costs and benefits of this approach.

Although the waste producers would not necessarily have to meet alt of the waste acceptance requirements (see Section 4.0), they would have to provide the treatment facility with detailed waste characteristics data. The repository operator would need this information to devise a suitable processing and/or certification scheme for each waste container. For example, untreated combustible materials would have to be treated in some manner before they can 
be certified for disposal, however, metallic wastes do not require treatment in most cases and thus, would only require NDE and assaying prior to disposal. Therefore, the waste producer should segregate their wastes according to physical or chemical form (i.e., individual waste containers should exclusively contain only one type of waste, such as combustibles, metallics, etc). This would facilitate identification of the appropriate processes needed to certify each waste container or disposal. If the producers do not segregate their wastes, the treatment facility would need to provide a system to perform the segregation operations with increased cost and complexity of facilities. 


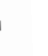




\section{REFERENCES}

Abei, K.H. et al. 1983. Residual_Radjonuclide Distribution and Inventory at the Humboldt Bay Nuclear Power Plant. PNL-4628, Pacif ic Northwest Laboratory, Richland, Washington.

Baker, D.A. 1984. List of DOE Radioi sotope Customers With Sumary of Radiojsotope Shipments - FY $=1983$. PNL-5126, Pacific Northwest Laboratory, Richland, Washington.

Bishoff, J.R. and R.J. Hudson. 1979. Early Waste Retrieval Final Report. TREE-1321, EGsG Idaho, Inc., Idaho Falls, Idaho.

Caldwe11, J. T. et al. 1983. Measurements of the Transuranic Content in Wastes," Nuc. Chem. Waste Management, Vol. 4, pp. 11-17.

Clements, T. L. et al. 1984. Processing and Certification of Defense Iransuranic Waste at the INEL. EGG-M-26083, EG\&G Idaho, Inc., Idaho Fal1s, Idaho.

Cline, J.E., K.L. Wright, and J.W. Hollcroft. 1980. Activity Levels of Iransuranic. Nuc]jdes in Low-leyel Solid Wastes from U.S. Power Reactors. EPRI-NP-1494, Prepared by Science Applications, Inc. for the Electric Power Research Institute, Paio Alto, California.

Crynar, J. C. et al. 1984. "Low-level and TRU Waste Management at West Valley." Proceedinos of Waste Management 1984, March 11-15, 1984, Tuscon, Arizona.

D'Ambrosia, J. T. et a]. 1984. "The Certification of Transuranic Waste." Proceedings of Waste Management 1984, March 11-15, 1984, Tuscon, Arizona.

Dennis, A.W. et a1. 1984. NWWSI Repository Operational orocedures for Receiving, Packaging, Emplacinge and Retrieving High-level and Iransuranic Waste. SAND83-1166, Sandia National Laboratories, Albuquerque, New Mexico.

DOE 1980. Einal Environmental_Impact Statement: Management of Commerciajly Generated Radioactive Waste, DOE/EIS-0046F, U.S. Department of Energy, Washington, D.C.

DOE. 1983. Spent Fuel and Radioactive Waste Inventories, Projections, and Characteristics. DOE/NE-0017/3, U.S. Department of Energy, Washington, D.C.

DOE. 1984. Spent Fuel and Radioactive Waste Inventories, Projections, and Characteristics, DOE/RW-0006, U.S. Department of Energy, Washington, D.C.

DOE. 1985. Mission Plan For the Civilian Radjoactive Waste Management Program. DOE/RW-0005. U.S. Department of Energy, Washington, D.C. 
Erfurdt, R. J. 1983. Chemical Systems Engineering Progress Report: January through December 1981. RFP-331, Rocky Flats Plant, Rockwe11 International, Golden, Colorado.

Freed, E. J. 1982. SRL Incinerator Components Test Facility. DP-1640, E. I. du Pont de Nemours and Co., Savannah River Laboratory, Aiken, South Carolina.

Gause, E.P. et al. 1983a. Characterization of the Radioactive Large Quantity Waste Package of the Unjon Carbide Corporation. NUREG/CR-2870, BNL-NUREG-51576, Brookhaven National Laboratory, Upton, New York.

Gause, E.P. et a1. 1983b. Characterization of the Class B Stable Radioactive Waste Packages of the New England Nuclear_Corporation. NUREG/CR-3018, ENL-NUREG-51787, Brookhaven National Laboratory, Upton, New York.

Hickle, G. L. 1984. Waste Systems_Progress Report: March 1983_through Eebruary 1984_. RFP-3682, Rocky Flats Plant, Rockwell Internationa1, Golden, Colorado.

Jenks, G.H. 1977. Maximum Acceptable Jemperatures of Wastes and Contafners During Retrievable Geologic Storage, Y/OWI/TM-42. Office of Waste Isolation, Union Carbide Corp., Oak Ridge, Tennessee.

Kempf, C.R. et a1. 1984a. Characterjzation of the Low-Ievel_Radioactlve Wastes and Waste Packages of General Electric Yallecitos Nuclear Center, NUREG/CR-3864, BNL-NUREG-51791, Brookhaven Nationa] Laboratory, Upton, New York.

Kempf, C.R. et a7. 1984b. Characterization of the Low-level Radieactixe Waste Packages of the Minnesota Mining and Manufacturing Co. NUREG/CR-3844, BN-NUREG-51787, Brookhaven Nationa] Laboratory, Upton, New York.

Kutrn, H.L., R.D. Peters, and S.A. Simonsen. 1983. "Development of a Leach Model for a Commercial Nuclear Waste Glass." Nuclear_Jechnelogy. Vol. 63. October, 1983. American Nuclear Society, LaGrange Park, Illinois.

Lea, F.M. 1971. Ihe Chemistry of Cement and Concrete. Th1rd Edition. Chemical Publishing Co. Inc., New York, New York.

Lepel, E.A. et al. 1984. Residual_Radjonuclide Distribution and Inventory at Indianfoint Station, Unit lne. PNL-5020, Pacific Northwest Laboratory, Rich1 and, Washington.

McClure, J. D. et al. 1985. Iechnical Criteria and Guidelines for Single Containment of Plutonjum-Bearing Solids for Transportation. SAND82-1715, TTC-0330, Sandia National Laboratories, Albuquerque, New Mexico.

McKee, R.W. et a1. 1984. "Economic Analys1s of Waste Management System A1ternatives for Reprocessing Wastes." Proceedings of Waste Management 1983. March 11-15, 1984, Tuscon, Arizona. 
Mckinley, et al. 1983. "The Stored Waste Examination Pilot Plant (SWEPP) at the INEL." Proceedings of Waste Management 1983, February 27 to March 3, 1983, Tuscon, Arizona.

Meile, L. J. 1982. Rocky Elats.PlantFluidized Bed Incinerator. RFP-3249, Rocky Flats Plant, Rockwell International, Golden, Colorado.

Mengeng, C.A., and G.R. Thayer. 1984. Beneficjal Uses of Am-24l. LA-10075-MS, Los Alamos National Laboratory, Los Alamos, New Mexico.

National Academy of Sciences (NAS). 1984. Reviey of the Scientific and Iechnical Criteria for the Waste Isolation Pilot Plant (WIPP). DOE/ DP/48015--1, Nationa I Academy Press, Washington, D.C.

Neville, A.M. 1981. Properties of Concrete. Third Edition, Pitman Publishing Inc., Marshfield, Massachusetts.

NRC. 1982. Nuclear Waste Management Technical Support in the Development of Nuclear Waste Form Criteria for the NRC; Task 2-Alternative IRU Technologies NUREG/CR-2333 Vol 2, U.S. Nuclear Regulatory Commission, Prepared by Brookhaven National Laboratory, Upton. New York.

NRC. 1984. Environmental Assessment for 10 CFR Part 72 "Licensing Requirements for the Independent Storage of Spent Fuel and High-level Radioactive Waste." U.S. Nuclear Regulatory Conmission, Division of Engineering Technology, Washington, D.C.

ORNL. 1984. Eeasibility Study for RH-IRU Waste Handling Facjlity. Oak Ridge Nationa 7 Laboratory, Oak Ridge, Tennessee.

Oversby, V.M. 1984. The Nevada Nuclear Waste Storage Investigations Project Interim Acceptance Specifications for Defense Waste Processing Facility and West Valley Demonstration Project Waste Forms and Canistered Waste. UCID-20165, Lawrence Livermore National Laboratory, Livemore, California.

ONWI. 1983. Conceptual Waste Package_Interim Product Specifications and Data Requirements for Disposal of Glass Commercial High-level Waste Forms in Salt Geologic Repositories. BMI/ONWI-521, Office of Nuclear Waste Isolation, Battel le Menorial Institute, Columbus, Ohio.

Parsons, Ralph. M.C. 1985. Integral Monitored Retrievable Storage (MRS). Eacility Conceptual Design Report. Voi. I, Book 2 "Design Description." MRS-11. Prepared for U.S. Department of Energy, Richtand Operations Office, Richland, Wastington.

Rahn, F.J. et a]. 1984. A Guide to Nuclear Power Technology. John Wil ey and Sons, New York, New York. 
Rockwe11. 1984. User's Manual for Remote-Handied_Iransuranic Waste Container. RHO-RE-MA-7, Rockwel? Hanford Operations, performed for Pacific Northwest Laboratory, Richland, Washington.

RFP. 2974. Plutonium in Oxide to be Shipoed to the Savannah River Plant. FET 898-74-116, Rocky Flats P1ant, Golden, Colorado.

Ross, W.A. et a1. 1985. Analysis of Ireatment Strategies for Iransuranic Wastes from Reprocessing Plants. PNL-5130, Pacific Northwest Laboratory, Richl and, Washington.

Schultz, F.J. et al. 1985. Neutron and Gamma-Ray Nondestructive Examination of Contact-Handled Iransuranic Waste at the_ORNL TRU Waste Drum Assay Facility. ORNL-6103, Oak Ridge National Laboratory, Oak Ridge, Tennessee.

Snyder, 8. J. 1984. Management of Solid Radioactive Waste from the TMI-2 Accident." Broceedings of Waste Management 1984. March 11-15, 1984, Tuscon, Arizona.

Stinebaugh, R.E. 1984. The Underground System for Disposal of Contact_Handled Iransuranic Waste at the NNWSI Repositorye SAND83-0343, Sandia National Laboratory, Albuquerque, New Mexico.

Tait, T. D. 1984. "Treatment of TRU Waste in the Process Experimental Pilot P1ant." Irans. Am. Nucl. Soce 46:113-114, American Nuclear Society, LaGrange Park, Il]inois.

Westinghouse. 1982. Waste Package Concepts for Use in the Conceptual Desion of the Nuclear Waste Repository in Basalt. AESD-TME-3142, Westinghouse Electric Corp., Pittsburgh, Pennsylvania.

Westinghouse. 1983 a. Engineered Waste Package System Design Specification. ONWI-4Z3, Westinghouse Electric Corp., Pittsburgh, Pennsylvania.

Westinghouse. 1983b. Engineered Waste Package Conceptual Desion: Defense High-level Waste (Form 1) Cammersial High-level Waste (Form 1), and Spent Euel (Form 2) Disposal in Salt. ONH I-438, Westinghouse Electric Corp., Pittsburgh, Pennsytvanja.

Westinghouse. 1983c. Cenceptual Waste Package Designs for Disposal of Nuclear Waste in Tuff. ONWI-439, Westinghouse Electric Corp., Pittsburgh, Pennsylvania.

West inghouse, 1984. IRU Waste Acceptance Criteria for the Waste Isolation Pllot Plant. WIPP-DOE-069 Rev. 2, Westinghouse Electric Corp, WIPP Technica? Support Contractor, Albuquerque, New Mexico.

Hobser, J. K. 1983. Nonradieactive Demonstration of the Alpha D8D Pilot Eacility, DP-MS-83-42, E. I. du Pont de Nemours and Co., Savannah River Laboratory, Aiken, South Carolina. 


\section{APPENDIX A}

RESULTS OF A SURVEY

OF POIENTIAL PRODUCERS OF

IRANSURANIC WASTES

$\checkmark$ 
APPENDIX_A

\section{RESULIS OF_A SURVEY OF \\ POTENTIAL PRODUCERS OE \\ IRANSURANIC WASTES}

This appendix presents the results of a survey of potential producers of TRU wastes. The wastes described in this appendix may ultimately be disposed in a commercial (or combined commercial/defense) radioactive waste disposal repository. This appendix provides summary information regarding these wastes. Additional details regarding waste forms, waste containers, and physical and radiological characteristics of the wastes were presented in Section 3.0

The information in this appendix is organized along the same 1 ines as Section 3.0. The summary table shown here corresponds to each subsection of Section 3.0. Show below is a 1 ist that cross-references the summary tables of which appendix with the corresponoing subsection of Section 3.0, that contains additiona 7 information.

Summary Table

Table A.I

Table A.2

Table A.3

Table A.4

Table A.5

\section{Cross-Reference}

Section 3.2.1

Section 3.2 .2

Section 3.2.3

Section 3.3.1

Section 3.3 .2

Some information in the following tables has been abbreviated. "Drums" means 55-gal drums unless specified otherwise. Where the term "1 iner" is used, the volume of the liner is $200 \mathrm{ft}^{3}$. "Box" is defined as a $4 \mathrm{ft} \times 4 \mathrm{ft} \times 4 \mathrm{ft}$ metal box. "N/A" means data was not provided or was "not gualtable." 
TABLE A.1. Summary of TRU Waste Quantities Generated at Commercial Nuclear Power Plants

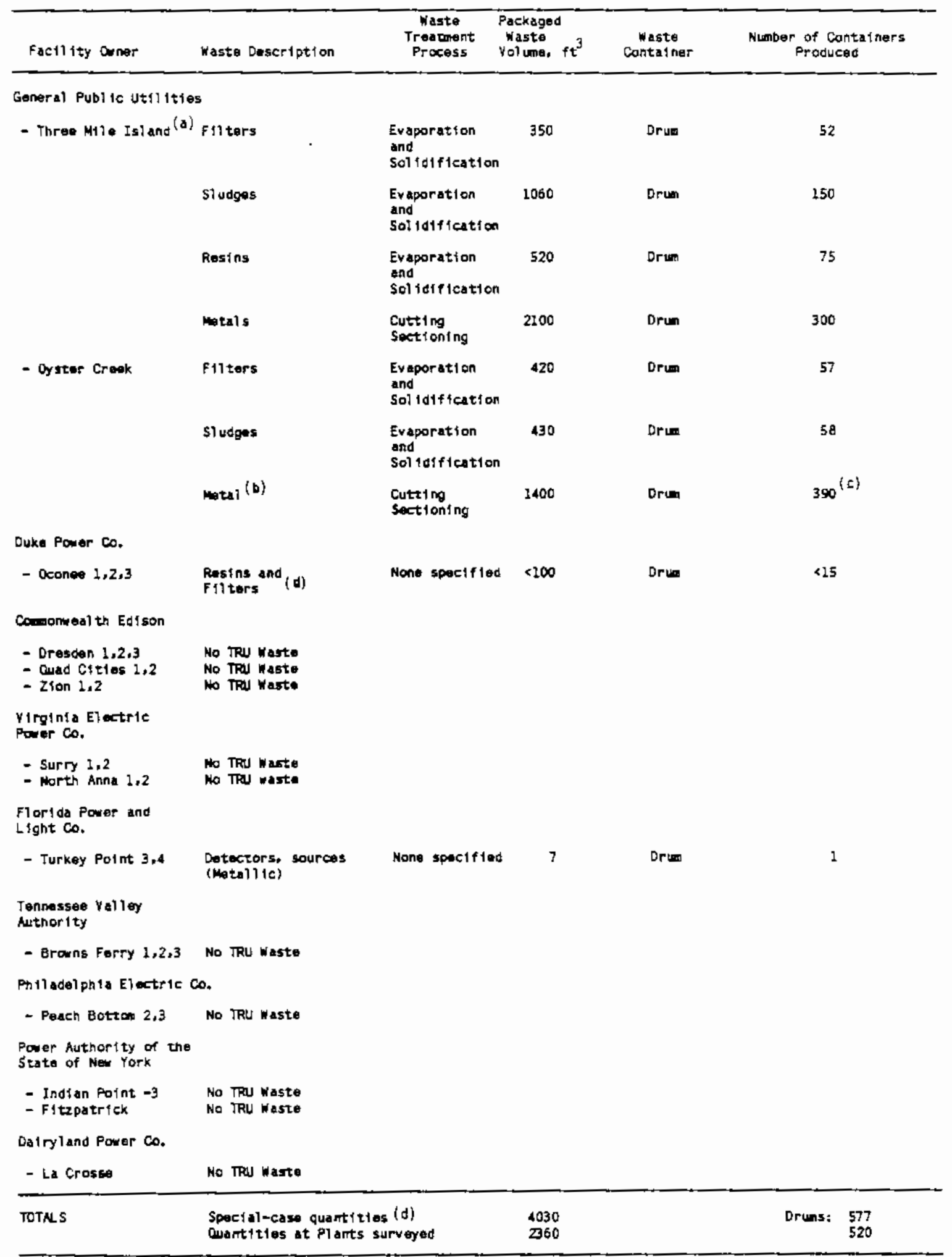

(a) Includes wastes from ThI-2 on $1 y$.

(b) Metal waste is irradiated equipment for which activity is unknown. May or may not be TRU nasto.

(c) Wastes are assumed to be packaged in 55-gal arums. A 50 packing fraction was assumed to calculate the number of containers producod.

(d) Activity is uncertain. May or may not be Thu wasto. 
TABLE A.2. Sumnary of TRU Waste Quantities Generated by the West Valley Demonstration Project (WVDP)

\begin{tabular}{|c|c|c|c|c|c|c|}
\hline WYOP Phase & Waste Description & $\begin{array}{l}\text { Trestment } \\
\text { Process }\end{array}$ & Yal une, $\mathrm{ft}^{3}$ & $\begin{array}{l}\text { Wasto } \\
\text { Contalnor (a) }\end{array}$ & $\begin{array}{l}\text { Nunter of } \\
\text { fro }\end{array}$ & $\begin{array}{l}\text { canta inars } \\
\text { ducad (b) }\end{array}$ \\
\hline \multirow[t]{4}{*}{ Pro-solidification } & Rubbish, trash & Compection & 2.000 & Dru & 270 & $(0)$ \\
\hline & $\begin{array}{l}\text { Spant resins and } \\
\text { f\$1 ters }\end{array}$ & $\begin{array}{l}\text { Dr1ed and } \\
\text { solidifted }\end{array}$ & 200 & Orian & 29 & $(200)$ \\
\hline & $\begin{array}{l}\text { Deconcanination } \\
\text { Solutions }\end{array}$ & $\begin{array}{l}\text { Drifed and } \\
\text { Sol } 1 \text { difled }\end{array}$ & 6.000 & Drun & 800 & $(100)$ \\
\hline & $\begin{array}{l}\text { Contao inated } \\
\text { Equi pment/ harowara }\end{array}$ & $\begin{array}{l}\text { Ot somantl a } \\
\text { and eut }\end{array}$ & 14,500 & Box & 175 & $(50)$ \\
\hline \multirow[t]{4}{*}{ Sol idtfication } & Rubbish. trash & Compacted & 5.500 & Orum & 750 & $(0)$ \\
\hline & $\begin{array}{l}\text { Spem resins and } \\
\text { flit tors }\end{array}$ & $\begin{array}{l}\text { Dried and } \\
\text { solfdifted }\end{array}$ & 500 & Drum & 73 & $(100)$ \\
\hline & $\begin{array}{l}\text { Decortam ination } \\
\text { Sol utions }\end{array}$ & $\begin{array}{l}\text { Orted and } \\
\text { Sol idis fed }\end{array}$ & 200 & Orum & 25 & $(100)$ \\
\hline & Fa17 ed Equipment & $\begin{array}{l}01 \text { mantle } \\
\text { and curt }\end{array}$ & 500 & $80 x$ & $E$ & $(50)$ \\
\hline \multirow[t]{6}{*}{ Post-sol idif lcation } & Rubo1sh, trash & Compact i on & 4.000 & Drun & 550 & $(0)$ \\
\hline & $\begin{array}{l}\text { Spent resins and } \\
\text { f } 91 \text { ters }\end{array}$ & $\begin{array}{l}\text { Dried and } \\
\text { solldif iad }\end{array}$ & 200 & Drum & 28 & $(100)$ \\
\hline & $\begin{array}{l}\text { Decontam } 1 \text { nat } \\
\text { Sol utions }\end{array}$ & $\begin{array}{l}\text { Dried and } \\
\text { 5olidified }\end{array}$ & 7.800 & Orum & 1,050 & $(200)$ \\
\hline & $\begin{array}{l}\text { Contan I nated } \\
\text { Equipment/ ha roware }\end{array}$ & $\begin{array}{l}\text { Dismartie } \\
\text { and cut }\end{array}$ & 16,000 & $B C x$ & 190 & $(50)$ \\
\hline & $\begin{array}{l}\text { Waste retrieral } \\
\text { equ1pent }\end{array}$ & $\begin{array}{l}\text { Disenamt } \theta \\
\text { and cut }\end{array}$ & 2,500 & Box & 30 & 1503 \\
\hline & $\begin{array}{l}\text { Contaminated } \\
\text { rubole }\end{array}$ & None & 11.500 & Box & 140 & $(0)$ \\
\hline \multirow[t]{2}{*}{ TOTALS } & & & 71.400 & Qrum & 3,587 & $\langle 56\rangle$ \\
\hline & & & & Box & $\$ 41$ & $(40)$ \\
\hline
\end{tabular}

(a) Waste contal ners are as fol tows: DRUM = 55-ga1 druma $1.7 \mathrm{~m} \times 1.4 \mathrm{~m} \times 1.0 \mathrm{~m}$

(b) Nunbers in parenthesis indicate the parcentage of the waste containers treated as remote nandied. 
TABLE A.3. Summary of TRU Waste Quantities Generated During Decontamination and Decommissioning of Mixed Oxide Fuel Fabrication Facilities

\begin{tabular}{|c|c|c|c|c|c|}
\hline Facility Owner & Waste Description & $\begin{array}{l}\text { Waste } \\
\text { Treatment } \\
\text { Process }\end{array}$ & $\begin{array}{l}\text { Packaged } \\
\text { Waste } \\
\text { Volume, ft }\end{array}$ & $\begin{array}{l}\text { Waste } \\
\text { Container }\end{array}$ & $\begin{array}{c}\text { Number of Containers } \\
\text { Produced }\end{array}$ \\
\hline \multirow[t]{2}{*}{$\begin{array}{l}\text { Nuclear Fuel Services } \\
\text { Irwin, TN }\end{array}$} & $\begin{array}{l}\text { Glove boxes and } \\
\text { associated equipment } \\
\text { (metallic) }\end{array}$ & $\begin{array}{l}\text { Cutting } \\
\text { Sizing }\end{array}$ & 5300 & Drum & 800 \\
\hline & $\begin{array}{l}\text { Liquids from } \\
\text { decontamination } \\
\text { operations }\end{array}$ & $\begin{array}{l}\text { Evaporation } \\
\text { and } \\
\text { solidifi- } \\
\text { catton }\end{array}$ & $\begin{array}{l}\text { Small } \\
\text { Volumes } \\
\text { Included } \\
\text { Above }\end{array}$ & Drum & Included above \\
\hline $\begin{array}{l}\text { Exxon Nuclear } \\
\text { Richland, WA }\end{array}$ & Metal11c wastes & None specified & 250 & Drum & 34 \\
\hline $\begin{array}{c}\text { Babcock and Wilcox } \\
\text { Lynchburg, VA }\end{array}$ & $\begin{array}{l}\text { Glove boxes and } \\
\text { associated equipment } \\
\text { (metallic); decon- } \\
\text { tamination solutions; } \\
\text { contaminated concrete, } \\
\text { soil, and bullding } \\
\text { rubble }\end{array}$ & $\begin{array}{l}\text { Metals-cutting } \\
\text { and sizing; } \\
\text { Solutions- } \\
\text { evaporation } \\
\text { and solidi- } \\
\text { fication; } \\
\text { Others-None }\end{array}$ & 1500 & Drum & 210 \\
\hline $\begin{array}{l}\text { Sequoyah Fuels Corp. } \\
\text { Oklahoma City, OK }\end{array}$ & $\begin{array}{l}\text { Glove boxes, storage } \\
\text { tanks, filters, pulse } \\
\text { columns (metallic); } \\
\text { glass; paper; plastics }\end{array}$ & $\begin{array}{l}\text { Metals-cutting } \\
\text { and sizing; } \\
\text { Others-None }\end{array}$ & 16,600 & Drums & 1840 \\
\hline
\end{tabular}




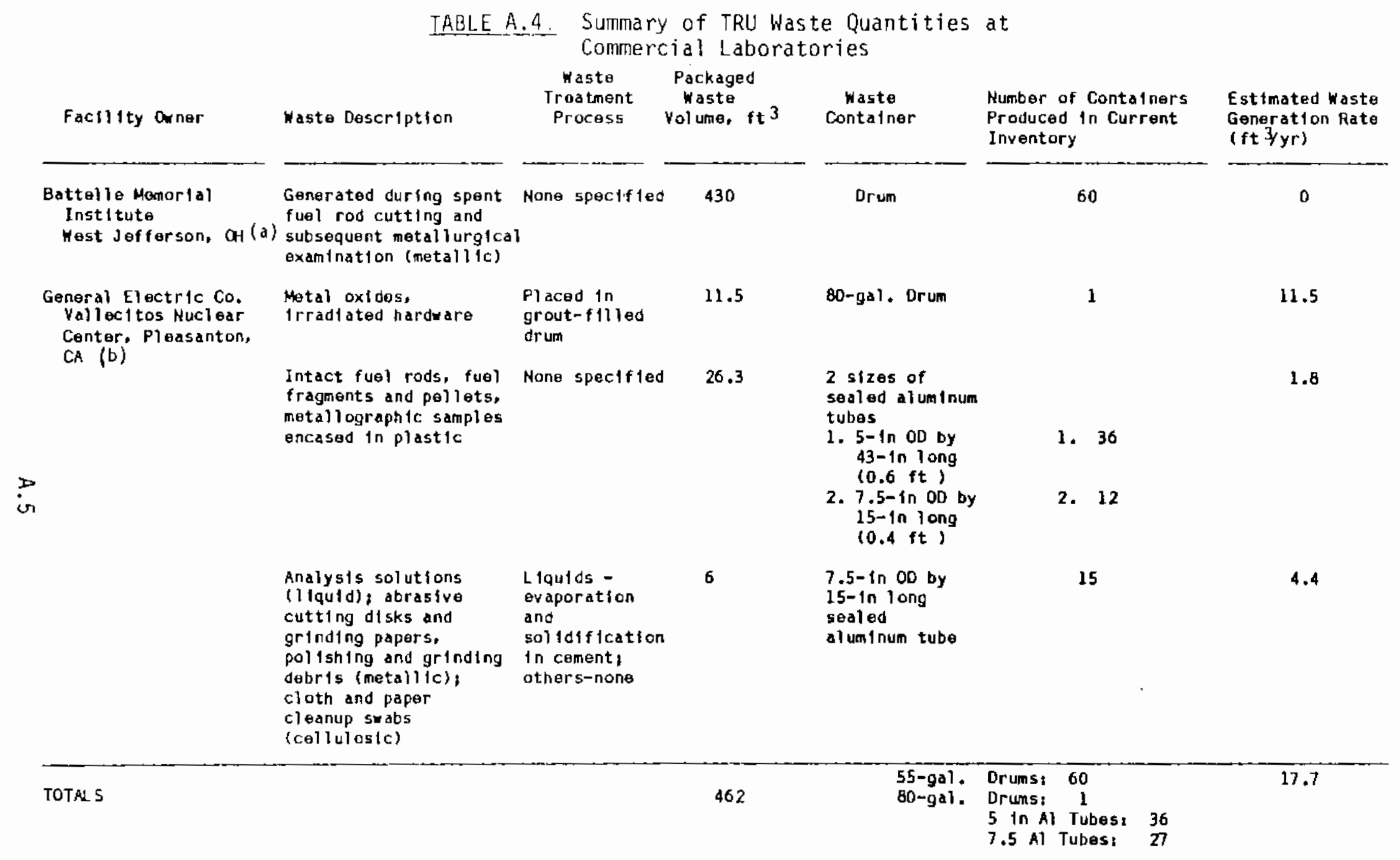

(a) Data obta1ned by telephone contacts uith Battelle staff.

(b) Data obtat ned from Kempf et al. $\{1984\}$ and telephone discusstons *Ith GE staff follored by a letter. 
TABLE A.5. Summary of TRU Wastes From Other Industrial Users of TRU Isotopes

\begin{tabular}{|c|c|c|c|c|c|}
\hline Factlity ouner & Waste Descriftion & $\begin{array}{l}\text { Kasto } \\
\text { Traatment } \\
\text { Process }\end{array}$ & $\begin{array}{l}\text { Fackaged Waste } \\
\text { Vol ume in Current } \\
\text { Inventory. ft } 3\end{array}$ & $\begin{array}{c}\text { Waste } \\
\text { Contatnor }\end{array}$ & $\begin{array}{c}\text { Est1mated Waste } \\
\text { Generat on Rate } \\
(\mathrm{ft} 3 / \mathrm{yr})\end{array}$ \\
\hline $\begin{array}{l}\text { Montanto Research Corp. } \\
\text { Davton, of }\end{array}$ & $\begin{array}{l}\text { Product 1on Trash (6cos } \\
\text { are combustibie papors } \\
\text { and plast fcs; } 10 \% \\
\text { I faulds; } 30 \text { tals) }\end{array}$ & $\begin{array}{l}\text { Licuidos - } \\
\text { ovaporated } \\
\text { and } \\
\text { solleftiod; } \\
\text { Othersenome }\end{array}$ & 550 & Drum & $110(a)$ \\
\hline$\cdot$ & $\begin{array}{l}D \text { atd } 0 \text { of gofolete } \\
\text { glova boxes }(b)\end{array}$ & $\begin{array}{l}\text { Remoral and } \\
\text { soct } 1 \text { oning }\end{array}$ & 800 & Orum & $0^{(b)}$ \\
\hline $\begin{array}{l}\text { Mershen Corp. } \\
\text { Arl ington HE., ILL. }\end{array}$ & $\begin{array}{l}\text { Tissue, paper, plastic, } \\
\text { folt }\end{array}$ & Hone spectifted & $T \mathrm{RJ} ; 0$ & Drum & $\operatorname{TR} ; 0$ \\
\hline \multirow{4}{*}{$\begin{array}{l}\text { Nuci adr Radiati on } \\
\text { Devel opment. Inc., } \\
\text { Grano Islanc. NY }\end{array}$} & $\begin{array}{l}\text { Wetall ic Eaul proent } \\
\text { (density } 50 \text { los } / \mathrm{ft} \text { ) }\end{array}$ & None specifiad & 83 & Drum & $g^{(c)}$ \\
\hline & $\begin{array}{l}\text { Scrap neta) (imcludes } \\
\text { Smoke detector foll; } \\
\text { dens1ty } 30 \text { ibs/ft } 3 \text { \} }\end{array}$ & None specif tod & 450 & Drum & $50\{d\}$ \\
\hline & $\begin{array}{l}\text { Conbust1b1es } \\
\text { (collulosics) } \\
\text { (density } 30 \text { lbs/ft }{ }^{3} \text { ) }\end{array}$ & Comoacti an & 1000 & Orwen & $140 / \mathrm{yr}$ \\
\hline & $\begin{array}{l}\text { Siudges } \\
\text { (density } 30 \mathrm{ibs} / \mathrm{ft} 3 \text { ) }\end{array}$ & Evaporation & 48 & Orum & $7(e)$ \\
\hline $\begin{array}{l}\text { Nucl bar Sources and } \\
\text { Services. Inc. } \\
\text { Houston, Tx }\end{array}$ & Sedied sources & No Tत्य Waste & & & \\
\hline $\begin{array}{l}\text { Ner Engiand Nuclear } \\
\text { Corp.. N. Billorica. } \\
\text { MA }\end{array}$ & $\begin{array}{l}\text { Combustible laboratory } \\
\text { trash (glores, bootles. } \\
\text { paper, atc.) }\end{array}$ & None spectefled & 350 & Drum & so \\
\hline \multirow[t]{2}{*}{$\begin{array}{l}\text { Gamma Industries } \\
\text { Baton Rouge, LA }\end{array}$} & Giov boxes (metallic) & None speciffied & 22 & NA & $\mathrm{N} / \mathrm{A}$ \\
\hline & Offagas f 11 ters & None specifled & $N / A$ & $N / A$ & $N / A$ \\
\hline $\begin{array}{l}\text { Isotops Products } \\
\text { Laboratorles } \\
\text { Burdank. Ch }\end{array}$ & $\begin{array}{l}\text { Mixed (Daper, stoe } \\
\text { covers, smail tools, } \\
\text { ion exchange resins) }\end{array}$ & None spectifiod & 7 & Drum & $7(f)$ \\
\hline $\begin{array}{l}\text { Gulf Nucloar, Inc. } \\
\text { wesstar. Tx }\end{array}$ & No TRU vastes & & 0 & $N / A$ & 0 \\
\hline $\begin{array}{l}\text { Radiatfon Service } \\
\text { Organfzation } \\
\text { Laure1, Mo }\end{array}$ & $\begin{array}{l}\text { Dedi orimarily with Lill: } \\
\text { not expected to produce } \\
\text { TRU wastes in lorge } \\
\text { volumes }\end{array}$ & & 0 & $N / A$ & 0 \\
\hline $\begin{array}{l}\text { Coratomics } \\
\text { Indiana. PA }\end{array}$ & $\begin{array}{l}\text { Heart pacemaker } \\
\text { fabricator; uses Pu= } 238 \\
\text { but does not generate } \\
\text { RUU nastes }\end{array}$ & & 0 & $N / A$ & 0 \\
\hline $\begin{array}{l}\text { E. A.0. Watallurofcal } \\
\text { Tondwanda. NY }\end{array}$ & No TRU rastes & & 0 & $N / A$ & 0 \\
\hline $\begin{array}{l}\text { Nuclear Researen Carp. } \\
\text { Warrington. PA }\end{array}$ & No TRU ustes & & 0 & NA & 0 \\
\hline $\begin{array}{l}\text { Tenneidec } \\
\text { Dak R1dge. Th }\end{array}$ & No TRU vastes & & 0 & $N / A$ & 0 \\
\hline $\begin{array}{l}\text { Amtech, Inc. } \\
\text { Tucson, } R Z\end{array}$ & No Try nastes & & 0 & $N / A$ & 0 \\
\hline
\end{tabular}

TOTNS

3310

Drums: 365

(a) Annual Ta्d waste generate rate is estimated to be 16 arwas/yr.

(b) These wastes are planned to be produced in the future when Monsanto decides

to reolace some oosolece glore box units. Thus these vaste are considared "spectal-case" uastes.

(c) Annual oroduction rate estimated to be $B \mathrm{ft} 3 / \mathrm{yr}$.

(d) Annual production rate estimated to be $50 \mathrm{ft} / \mathrm{yr}$.

(a) Annual production rate as not provlded by Nro.

(f) This company oroduces tro to throe drums of LLK annually. 
APPENDIX B

A CONCEPTUAL WASIE CERTIEICATION PLAN

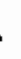




\section{A CONCEPTUAL WASTE CERTIFICATION PLAN}

Certification that TRU waste forms produced by various sources meet the waste acceptance requirements described previously witi be required. Waste producers will be required to establish a waste certification plan that describes the methods and procedures used to meet applicable TRU waste acceptance and quality assurance (OA) requirements. The certification plan describes the overall strategy of a certification program, including the identification of all activities, with their controls and supporting data, performed for the generation, processing, and certification of TRU wastes to be emplaced in a repository. The purpose of the certification plan is to document controls and supporting data to provide a traceable, auditable account of certification activities (Whitty et al. 1983).

Controls include specific processes and procedures that are designed to ensure waste packages are prepared which conform to applicable waste acceptance requirements. Control activities should be described in the certification pian, and may include references to such documents as procedures manuals for process operation, administration, nondestructive measurements and laboratory testing (including health physics measurements and testing). Whitty et a]. (1983) listed the following examples of process and OA-related controls, which included procedures for:

- waste generation

- waste classification/segregation

- waste treatment

- container preparation

- packaging

- color-coding and labeling

- data package preparation

- certification

- interim storage/shipment
- corrective actions

- records management

- personnel training

- inspection and testing

- procurement

- nonconforming item disposition

- design

- management control 
Supporting data includes documents and records that support and justify the provisions in the certification plan that are necessary to assure compliance with the waste acceptance requirements. Examples of such data include: 1) topical reports on waste form characteristics and waste form and container acceptance testing programs, 2) procurement specifications, and 3) calibration records. Process and QA-related supporting data would include information related to (whitty et ai. 1983):

- certifiable waste forms

- waste generation process

- waste treatment process

- procu rements

- container design/fabrication
- operations

- calibration records

- surveitlance/audit results

- personnel qualifications

- measurement control records

\section{B.1 ELEMENTS OF A CERTIFICATION PLAN}

The certification plan must address all the activities of a waste producer that are designed to ensure that waste containers and their contents are prepared in accordance with applicable waste acceptance requirements. The primary elements of a certification plan are shown in Table B.1. Each producer should use whatever equipment and procedures are necessary and appropriate for assuring compliance. These elements are described in detail by whitty et al. (1983) and are summarized in the following subsections.

\section{B.1.1 Purpose and Features}

A description is required of the purpose and requirements for certification, including an overview of waste-generating operations, and a description of the scope and organization of the plan. The requirements for certification would include the waste acceptance requirements, compliance requirements, DOE orders, NRC regulations, and site-specific health, safety and operational requirements. 
TABLEB.1. Elements of a Certification Plan (Whitty et al. 1983)

PURPOSE AND FEATURES

Purpose and Requirements for Certification

Overview of Waste-Generating Operations

Scope and Organization of the Certification Plan

WASTE GENERATION AND MANAGEMENT: ORGANIZATIONAL STRUCTURES

AND INTERFACES

General Organization Chart

Infrastructure of the Organization Chart

DATA COLLECTION AND ARCHIVING

CONTAINER PROCUREMENT AND HANDL ING

Oescription of Waste Containers

Control Methods

WASTE GENERATION AND TREATMENT

General Description of Primary Waste Generation and Treatment

List of Certifiable and Noncertifiable Waste Forms

SPECIFIC CERTIFICATION PROCEDURES: ATTACHMENTS TO THE PLAN

Introduction

Waste Form Description

Waste Form and Packaging Control Methods

Data Package

B.3 


\section{B.1.2 Waste Generation and Management; Organizational_Structures and Interfaces}

An outijne is required of the responsibilities and interfaces of the various departments within the waste producer's organization that participate in the certification program (including the QA department). The major lines of authority and communication that would exist should be identified. This section should aiso list the formal offjces and job titles of key personnel.

\section{B.1.3 Data Collection and Archiving}

Information and data relating to instrument calibrations, container loading logs, assay measurements, health physics examinations, administrative control records, corrective action reports on damaged and repackaged waste packages, and other pertinent requirements must be collected and stored. A storage period by the waste producer of at least 25 years may be appropriate.

Standardized data sheets similar to the waste form (see Figure B.1) and waste package (see Figure B.2) data sheets developed at the Oak Ridge National Laboratory (ORNL) (Box and Setaro 1985) should be developed by each waste producer. The data sheets and other appropriate records, including copies of the data packages, shipping records, and certification documentation, should be stored in a standard manner in a particular location.

\section{B.1.4 Container Procurement and Handing}

A number of requirements are placed on waste containers to ensure their acceptability as a part of the waste disposal system. For example, waste containers must be noncombustible and must be shown not to fail after a specified drop test. This section of the certification plan should describe in detail the waste containers and the controls used to ensure waste acceptance 


\section{FILL IN AND SIGN THE LOG-IN SHEET FOR EACH PACKET PLACED IN THIS DRUM}

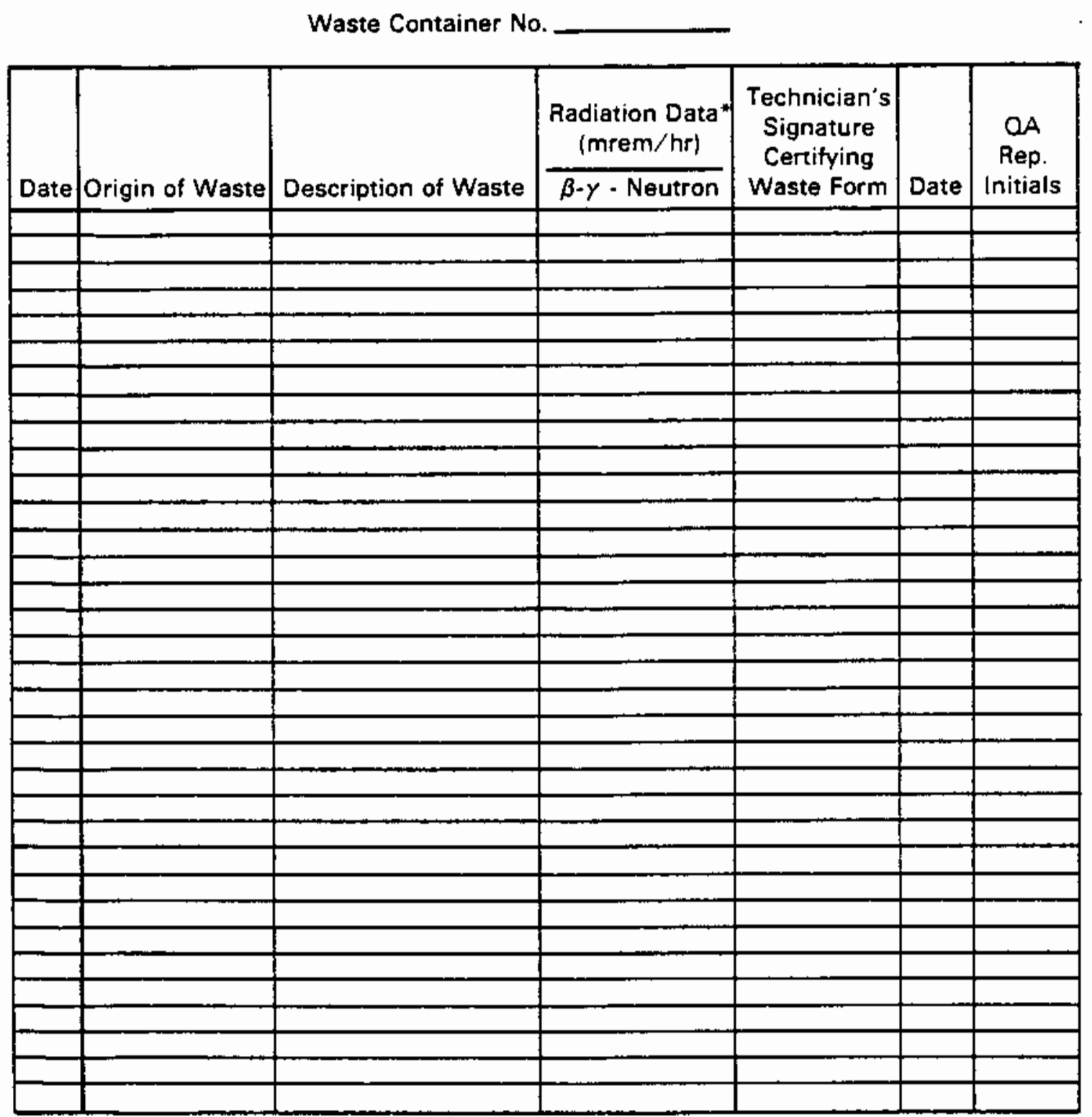

*If less than $5 \mathrm{mrem} / \mathrm{hr}$, record as $<5 \mathrm{mrem} / \mathrm{hr}$. If, after the packet has been placed in the drum, there is a $\beta-\gamma$ reading $>100 \mathrm{mrem} / \mathrm{hr}$ through the drum wall, have H.P. verify this dose rate.

FIGURE B.1. Waste Form Check List (Box and Setaro 1984) 


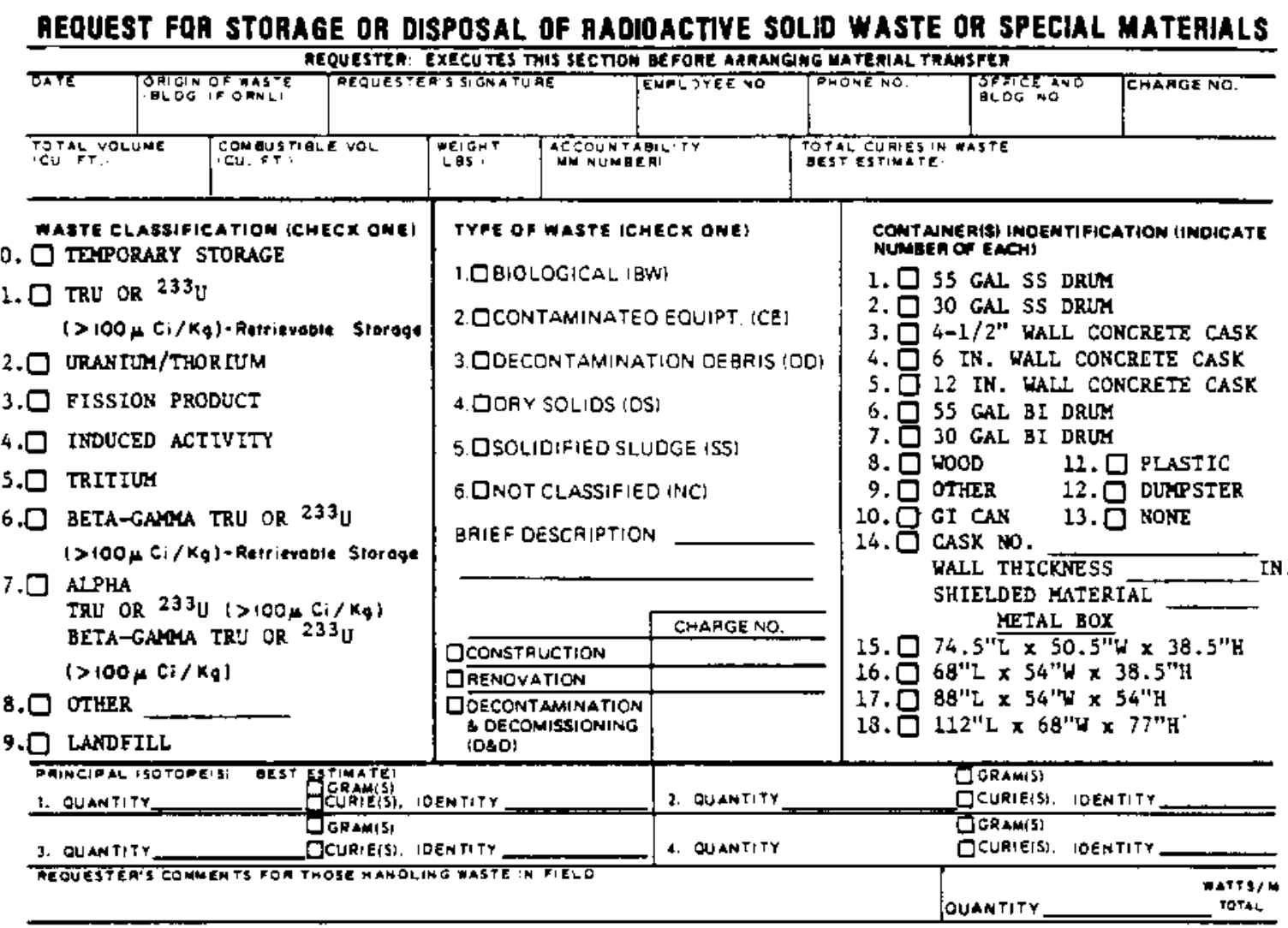

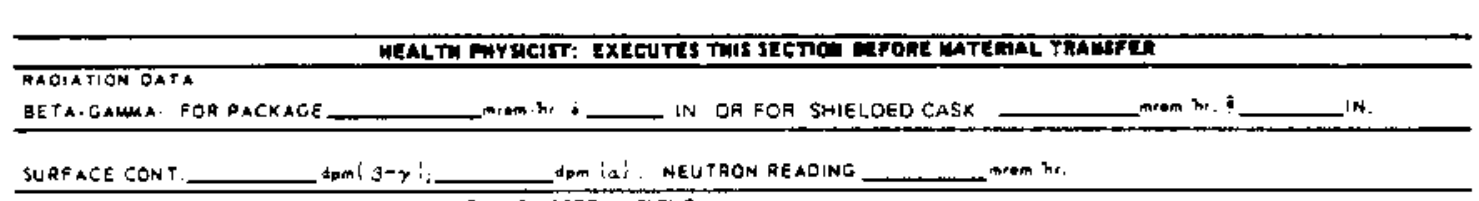

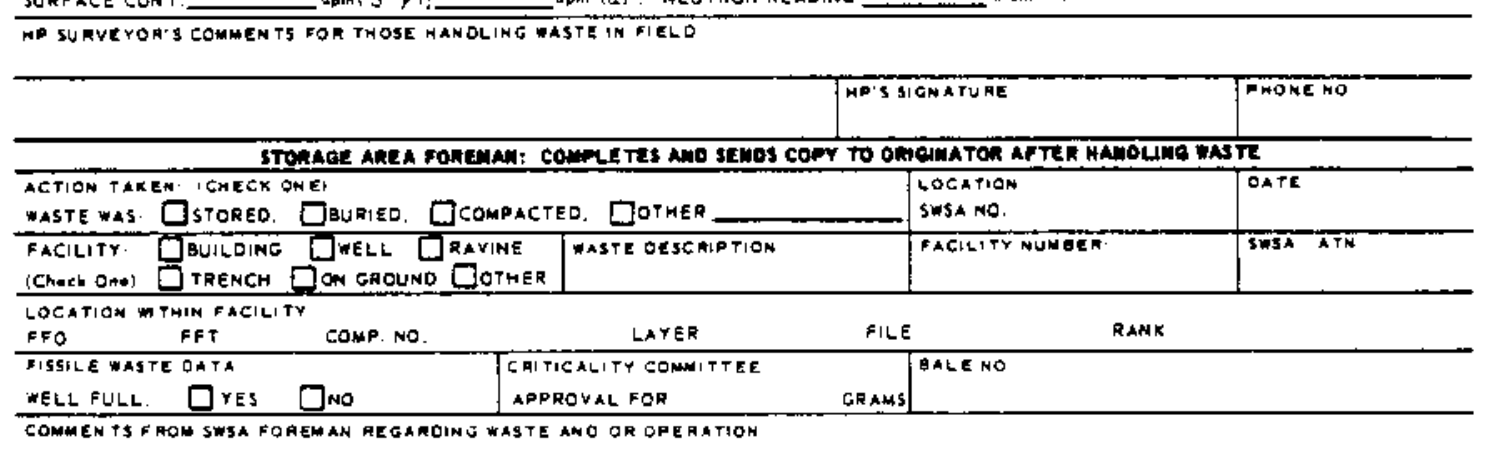

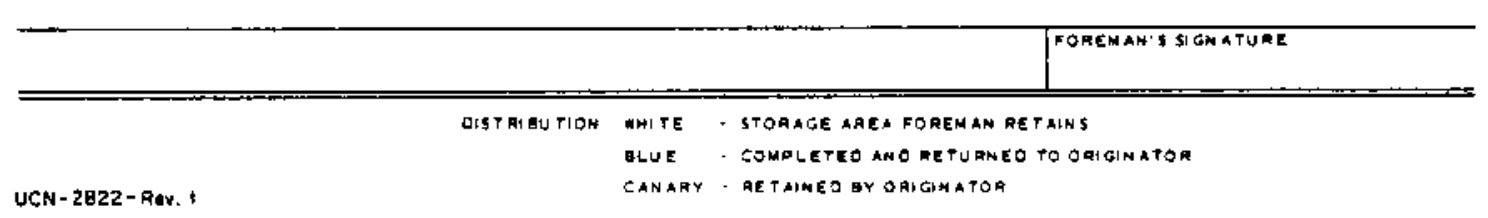

FIGURE B.2. Waste Package Data Sheet (Box and Setaro 1984) 
requirements are met, including procurement specifications and QA procedures. Controls on waste containers must ensure that they meet applicable waste acceptance requirements and that they are undamaged upon delivery to the waste producer as well as before and after waste packaging operations. Visual inspections may be used to certify that drums are undamaged.

\section{B.1.5 Waste Generation and Ireatment}

A general description is required of waste generation, treatment, handing, and packaging operations that are used to produce the certifiable wastes. A 7 ist of certifiable and currently uncertifiable waste forms should be presented, as well as discussions of the rationale that establishes a particular waste form as certifiable. Treatment processes to meet applicable waste acceptance requirements should be identified.

\section{B.1.6 Specific Certification Procedures}

A step-by-step description is required of the procedures that are necessary to ensure that each waste form and container meets applicable waste acceptance requirements. Separate procedures may vary among waste forms and shouid be written for each distinctly different waste form that is produced (e.g., noncombustible solids, incinerated and immobilized materials, 1iquids). It is recommended that the procedures for certification of each waste type should comprise a "stand-alone document" to facilitate updates and revisions to the certification plan.

Whitty et a1. (1983) suggests that each stand-alone document include a detailed description of the waste form, a discussion that 11 lustrates the progression of the waste form from generation through packaging and certification (including related control methods) and preparation of the data package. The data package, together with controls procedures and processes for assuring compliance, provides the bases for establishing that waste forms and containers are prepared in accordance with applicable waste acceptance requirements. Haste producers will be required to prepare a certification 
statement that indicaies that waste generation, treatment, handling and packaging operations have been performed properly. All information in the data package must be reviewed and each site's certifying authority must be confident that all data are correct and recorded properly.

Specific certification procedures associated with each waste acceptance requirement are described in Section 5.0 under the heading "Assuring Compliance." These, or similar procedures must be used by the waste producer to ensure that the wastes meet applicable acceptance requirements. The certification procedures document(s) should include statements of all of the waste acceptance requirements as well as discussions of the certification procedures used to assure compliance.

\section{B.2 CERTIF ICATION QUALITY ASSURANCE REOUIREMENTS}

Quality assurance ( $O / A$ ) has been defined as all of those planned and systematic actions necessary to provide adequate confidence that a facility, structure, system, component, or process will perform satisfactorily in service. Quality assurance includes quality control ( $O C$ ), which comprises all those actions necessary to control and verify the features and characteristics of a material, process, product, or service to specified requirements (10 CFR 50, Appendix B; DOE Order 5700.6A, WIPP DOE 120, Rev. 1). If the QA activities are effective, the documentation related to waste certification will be valid and adequate for performing the waste package certification activities.

\section{B.2.1 Design of a Certification OA Plan}

DOE order 5700.6A requires all DOE programs and their contractors to have QA. It is likely that commercial TRU waste shipped to a repository will have to meet quality assurance requirements similar to those specified for defense TRU waste that will be shipped to the WIPP. These requirements (WIPP-DOE 120, Rev. 1) were adapted from the basic requirements of NQA-1. The following principies must be considered: 
- Primary emphasis shall be on achieving a high degree of operational success, recognizing that safety, environmental protection, reliability, and performance are integraily related through the compliance requirements.

- QA activities shall be identified to the extent to which the certification oA requirements shall be applíed.

- Organizational responsibility and authority for activities affecting waste processing and certification shall provide for the effective implementation of the certification program and command effective management support.

- The certification plan must be amenable to internal and external audits and surveillance.

These principles must be incorporated in the TRU wastes certification plan prepared by the waste producer. The plan should be an integral part of the overali QA plan enforced by waste producer. Administrative procedures must be developed to assure $\mathrm{OA}$ compliance and document operating procedures. These procedures will be specific to each waste producer.

\section{B.2.2 Eeatures of a Certification OA Plan}

The certification QA plan must define all those planned and systematic activities which will ensure that each waste producer's TRU waste certification program will perform satisfactorily. These activities have been defined in 10 CFR 50, Appendix B, and are summarized below.

\section{B.2.2.1 Organization and Responsibilities}

The TRU waste certification OA organization must be identified and described. The organization must have the authority, organizational freedom and access to relevant site management at a level where appropriate action can be effected. The organization and responsibilities of the OA function must be 
established by each waste producer. An organizational arrangement similar to the arrangement shown on Figure B.3 should be established by each producer.

\section{B.2.2.2 Design Control}

Design control should apply to waste containers, selected waste forms, packages and processes. New container designs should be subject to procedures for qualifying container designs to satisfy Department of Transportation (DOT) specifications or applicable waste acceptance requirements. Approved containers are covered under "Control of Purchased Equipment, Material and Services" below. However, waste producer and vendor or contractor personnel responsible for designs, as well as independent verification activities based on sampiing by $Q A$ personnet, must be identified.

It is likely that waste container design verification, waste form identification and specification and other design activities can be accomplished by design review, tests, or calculation methods. These administrative controls will be described in the OA plan that will be prepared for each TRU waste Certification Program.

\section{B.2.2.3 Erocurement Document Control}

Ordering divisions of each waste producer will be responsible for ensuring that documents necessary for procurement (such as plans, specifications, engineering drawings, instructions, procedures, codes, standards, requisitions, and purchase orders) are prepared and are made a part of the contracts with vendors. Quality-related subjects that are covered by documents such as these are source selection and evaluation, supplier's OA program, material inspections, nondestructive examination, fabrication, processing, documented supplier reports and due dates, supplier data packages, supplier certifications, supplier nonconformances, supplier deviations, OA audits, source surveillance and inspection, shipping, operating manuals, equipment acceptance tests, and qual ity records. 


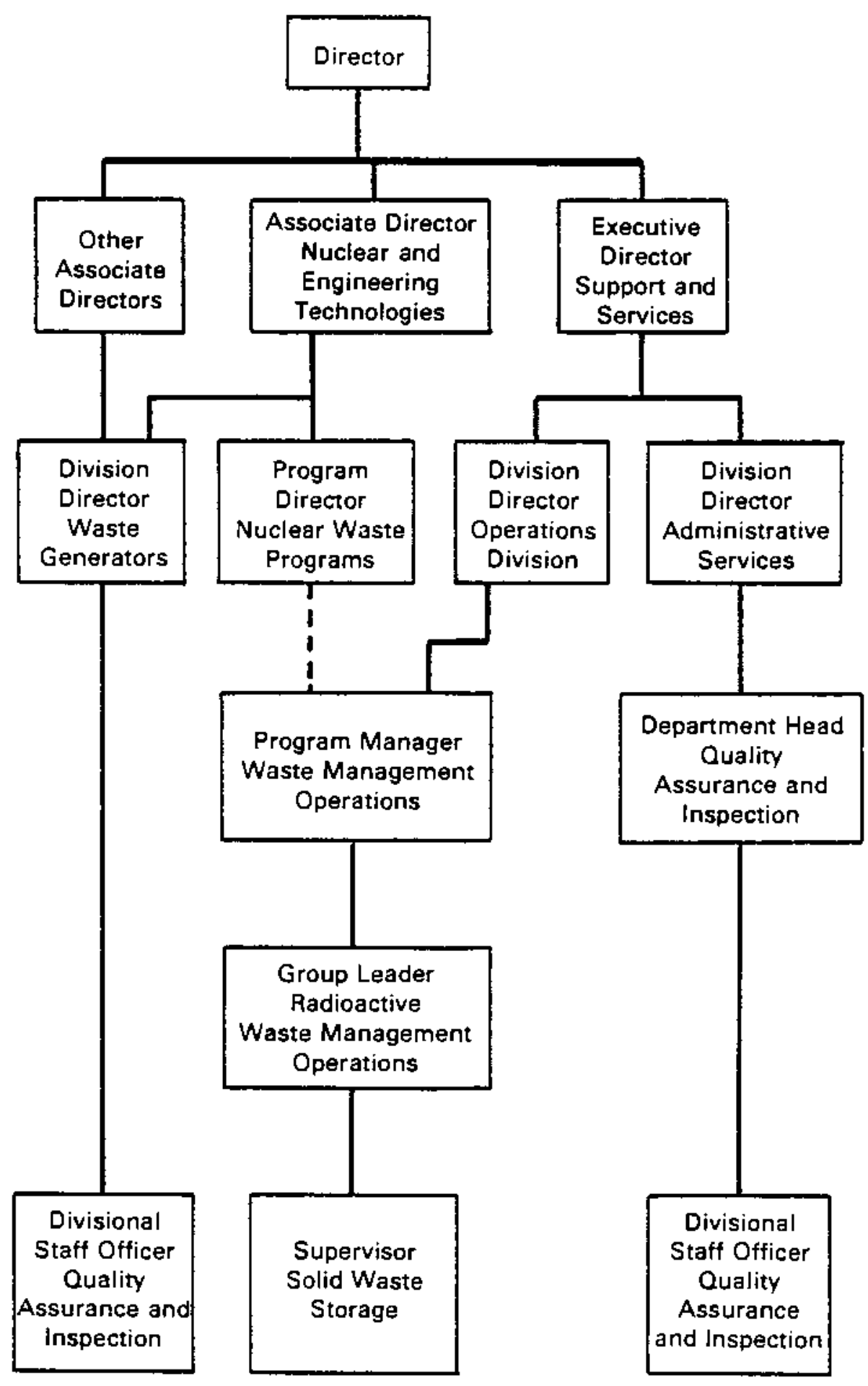

FIGURE B.3. Organization Chart of ORNL Quality Assurance Program (Box and Setaro 1984) 


\section{B.2.2.4 Instructions, Procedures and Drawings}

Activities affecting quality will be controlied by procedures contained in each waste producer's OA Manual. These procedures will be approved by division or program directors.

Operating procedures and/or work instructions w111 be prepared by the iine organization for predetermined conditions of startup, normal, shutdown, and emergency operations. Operating logs and check lists will be used to record actual operating events. Operational reviews will be conducted periodically to evaluate the methods and procedures used in operating the project.

\section{B.2.2.5 Document Control}

Documents (such as plans, drawings, speciflcations, procedures, and instructions) that establish the item description and quality requirements or that prescribe inspections and tests to determine compliance of the completed item with technical requirements are defined as quality-related documents.

Quality-related documents will be approved by a designated individual. These approvals verify that particular control requirements applicable to the document have been satisfjed and that the designated individual certifies that the document is acceptable for its intended use. Understanding and acceptance are fndicated by the signature and the date on the document.

The initial release and distribution of documents and changes thereto are the responsibility of a designated releasing authority. The releasing authority is also responsible for directing the user in how to dispose of obsolete quality-related documents previously issued and for obtaining any necessary verification that such action has been taken, whenever required by the complexity of the project.

Controlled quality-related documents will be uniquely numbered and identified on a controlled master 1 ist so that the letter or number to 
designate the current issue can be quickly and easily checked to ensure that the most up-to-date version of a document is used. This 1 ist will be updated on a periodic basis as documents are changed and reissued.

\section{B.2.2.6 Control of Purchased Material, Equipment and Services}

Source surveillance of supplies and manufacturers of purchased items and services that significantly affect certification will be performed by designated personnel during the course of a procurement. Surveillance personnel will include in their reports recommendations for any required corrective action. A11 purchased material will be inspected at the source or upon recefpt. These inspections wil1 be identified and documented.

Data packages on completed items will be submitted to the purchaser after being reviewed for compliance with technical and quality-related requirements. Receiving-inspection results and all quality-verification documentation submitted by the supplier w11l be transmitted to the purchaser. Nonconformances w11l be transmitted to the Contract Administrator of the waste producer's Purchasing Division so that contracts will not be closed out until corrective measures are taken and the item is fit for its intended use.

\section{B.2.2.7 Identification and Control of Items}

Special high-quality items (including instruments, materials, parts, components and subassemblies) will be identified in a manner that provides direct traceability to the documentation that verifies the acceptability of the items. This means of control will be established to ensure that nonconforming materials, parts, and components that have been rejected wili not be used. Supplier-provided items will be identified and documented by the supplier in a manner consistent with applicable codes or in the manner specified in procurement documents.

After the waste producer receives the materials, parts, and components, inspections $w i 11$ be made according to preplanned procedures and test 
specifications. If the items are incorrectly identified or incorrectiy documented, they will not be accepted until the condition is resolved.

A system will be developed to assure that the flow of TRU waste is identified from receipt at the receiving dock of the waste producer through waste treatment, certification and shipping.

\subsubsection{Control of Processes}

The use of nondestructive testing techniques le.g., x-ray, neutron, gamma, 41 trasonics), weided containers, and other specialized equipment makes process control necessary for each waste producer. The application of a special process will be specified on the applicable drawing of the component, system, or structure. Special processes wi11 be performed in accordance with written procedures or instructions, and means will be provided for recording evidence of verification of the processes.

Personnel, procedures, and equipment associated with metai joining and nondestructive examination (NDE) will be qualified, and the results documented in accordance with the requirements of ASME or other applicable codes, or in accordance with specially developed procedures. The supervisors of special processes will be responsible for ensuring that personnel under their supervision are qualified to perform a particular process. When qualification records are required, they will be maintained by the cognizant supervisor of the particular special process.

\section{B.2.2.9 Inspection}

Al1 material received from suppliers is routinely inspected for damage, quality, and item descriptions. Special inspections are performed, when required, in accordance with requirements contained on purchase requisitions. 
Quality control inspection procedures witl be defined for waste forms, waste containers and waste packages. A11 inspections will be performed by independent inspectors using written procedures. Independent monitoring of processing methods, equipment and personnel shall be described that will satisfy inspection requirements, when direct inspections are not possible.

\section{B.2.2.10 Test Control}

Test control consists of NDE of the waste package prior to certification. The NDE methods will include $x$-ray examination to ensure compliance with waste form criteria (immobilization, free liquids, sludges, compressed gases, combustibilityl and neutron interrogation and gamma assaying to ensure compliance with radioactivity criteria. The records generated in these tests will be retained onsite for 25 years (or other suitable period) after shipment to the repository.

\section{B.2.2.11 Control of Measuring and Test Equiement}

Calibration control will be achieved by following procedures that describe calibration techniques and requirements for the frequency of calibration of the operating instruments. This means control will ensure that all instruments, gauges, and related equipment are calibrated to the required accuracies. The supervisor responsible for operations will ensure enforcement of the calibration controls. Calibration records will be documented.

\section{B.2.2.12 Handling, Storage and Shipoing}

Special requjrements for handling, storage, shipping, cleaning, and preservation will be specified on drawings, specifications, instructions, and work-authorizing documents. These documents will be verified via a review and approval procedure by qualified project and $Q A$ personnel. Special handing tools and equipment $w i l l$ be inspected and tested in accordance with requirements on drawings, specifications, and work-authorizing documents. 


\section{B.2.2.13 Inspection, Testing and Operating Status}

Each package will be subjected to inspection and testing by gamma and neutron interrogation assay systems and $x$-ray examination. The status of each package will be plalnly marked on check sheets or on tags attached to the package. Any package containing treated waste that fails to meet the repository waste acceptance requirements will be returned to the treatment facility for additional processing. Approved packages will be identified and segregated in preparation for shipment.

\section{B.2.2.14 Control of Packages}

Written procedures will govern the action that should be taken upon discovery of nonconforming items and also govern their control, identification, reporting, and disposition. The control actions specified in these procedures will be applied through tests and inspections during inplant or vendor manufacture, receiving of purchased items, installation, and preoperational evaluation. Items that do not conform to required specifications will be documented, segregated, and evaluated. Provisions will be made for disposition of nonconforming items, which shall be appropriately marked to ensure their proper disposition.

\section{B.2.2.15 Corrective Action}

Unusual or unplanned events that have an adverse effect on quality (such as malfunctions, unapproved deviations, and other quality problems) will be noted in nonconformance reports, unusual occurrence reports, or quality investigation reports. Where such conditions indicate that the quality system requires improvement or modification, actions will be taken to identify the particular problem and to determine appropriate measures that will correct the condition and preclude a recurrence. The identification, cause, and corrective action resulting from unusual events will be documented and reported to appropriate levels of management. Follow-up action will be taken to verify that corrective actions have been successful. 


\section{B.2.2.16 Certification Recerds}

Records pertaining to the purchase, fabrication, and approval of waste containers to be used for shipment of waste to the repository will be maintained by the waste producer. In addition, operating logs, design reviews, inspection data, test results, calibration documents, nonconformance reports, drawings, specifications, procurement documents, audit reports, and qualification records for procedures, personnel, and equipment will be collected and stored for 25 years (or other suitable perlod). The individuals who collected the information, and the means used to collect and record the information will be descríbed.

\section{B.2.2.17 QA Audits}

An independent audit program will be developed to determine effectiveness of the waste producer's Certification Program. The audits will be performed by trained, independent auditors using written procedures or checklists. Audit findings will be documented and distributed to the DOE and waste producer. An independent check shall be made to assure that deficiencies are corrected.

Quality assurance and QC audits of suppliers will normally be conducted by qual ified personne? from the waste producer and/or by other experts selected by the waste producer's management. These audits are scheduled by the waste producer's management on the basis of quality requirements. 


\section{REFERENCES FOR APPENDIX B}

Box, W. D. and J. Setaro. 1984. Certification Docunient for Newly Generated Contact-Handled_Iransuranic Waste. ORNL/5985, Oak Ridge National Laboratory, Oak Ridge, TN.

Code of Federal Regulationse Titie 10, Part 50, Appendix B "Qual ity Assurance Criteria for Nuclear Power Plants and Fuel Reprocessing Plants."

Quality Assurance Program Requirements for Nuclear Facilities. ANSI/ASME NOA-1 (1983 edition), American Society of Mechanical Engineers, New York, New York.

U.S. Department of Energy (DOE) 1981. Quality Assurance, DOE Order 5700-6A, Washíngton, D.C.

Westinghouse. 1983. Qual ity Assurance Requirements for Certification of TRU Waste for Shipment to the WIPP. WIPP-DOE-120, Rev. 1, Westinghouse Electrical Corporation, Albuquerque, New Mexico.

Whitty, W. J. et a). 1983. Guidelines for Developing Certification Prosrams for Newly Generated TRU Waste, RFP-3554, Los Alamos, National Laboratory, Los Alamos, New Mexico. 
$\mathrm{PNL}-5597$

UC -70

DISTRIBUTION

No. of

Copjes

Ne_. of

Copies

OEESITE

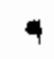

R. W. Bown

$R W-30$

Office of Civilian Fiadoactive Waste Managenent U.S. Department of Energy Washington, D.C. 20585

J. H. Carlson

$\mathrm{R} k-32$

Office of Civilian kágioactive Waste Managerient

U.S. Department of Energy Washington, D.C. 20585

C. W. Conner

$\mathrm{RW}-33$

Office of Civilian Radioactive Waste Mana gement U.S. Department of Energy Washington, D.C. 20585

F. P. Falci

$\mathrm{DP}-123$

U.S. Department of Energy Washington, D.C. 20585

Mark Frei

$\mathrm{RW}-23$

Office of Civilian fiadioactive Waste Management U.S. Department of Energy Washington, C.C. 20585

J. R. Hilley

$\mathrm{RN}-30$

Office of Civitian Radioactive haste Management

U.S. Department of Energy

Washington, D.C. 20585

T. H. Issacs

$\mathrm{FW}-42$

Office of Civilian Radioactive Haste Management U.S. Department of Energy Washingtor, D.C. 20585
M. M. McFadden

U.S. Department of Energy

Albuquerque Operations Ciffice

P. O. Box 5400

Albuguergue, N!M 87115

V. M. Oversby

Law rence Livermore National Laboratory

University of CaTifornia

P. O. Box 808

Livernore, CA 94550

W. A. Carbiener

Eattelle Merorial Institute $505 \mathrm{King}$ Avenue

Col umbus, $\mathrm{OH} 43201$

R. A. Robinson

Battel le Niemorial Institute $505 \mathrm{King}$ Avenue

Col umbus, OH 43201

R. W. Lambert

Electric Power Research Institute

3412 Hillview Avenue

Palo A7to, CA 94303

2 Ed Benz

Roy F. Heston

2301 Research Blvd.

Third Floor

Rockvitie, MD 20850

Rebecca Hansen

Roy F. Weston

2301 Research Elva.

Thiro Floor

Rockville, MD 20850

30 DOE Technical Information Center 


\section{OFFSITE}

J. O. Neff

National Haste Terminal

Storage Program

$505 \mathrm{King}$ Avenue

Columbus, CH 42301

S. Mann

U.S. Department of Energy

9800 S. Cass Avenue

Argonne, IL 60439

K. A. Klein

$\mathrm{BN}-32$

Office of Civilian Radioactive Waste Managerent

U.S. Departrent of Energy

Washington, D.C. 20585

T. D. Nguyen

$\mathrm{FW}-33$

Office of Civilian Radioactive Waste Management

U.S. Department of Energy

Washington, D.C. 20585

R. Philpott

$\mathrm{RW}-33$

Office of Civilian Raloactive Waste Management

Washington, D.C. 20585

B. Rawles

Battelle Memorial Institute

$505 \mathrm{King}$ Avenue

Columbus, $\mathrm{OH} 43201$

E. L. Wiาmot

$R W-33$

Office of Civilian Radioactive Waste Management

U.S. Department of Energy

C. W. Forsberg

Oak Ridge National Laboratory

P.0. Box $X$

Oak Ridge, TN 37380

J. A, Klein

Oak Ridge National Laboratory

P. 0. Box $X$

Oak Ridge, TX 37830
D. L. Vieth

U.S. Departrient of Energy

Nevada Operations Office

P.0. Box 14100

Las Vegas, NV 89114

G. Ishmae1

U.S. Department of Energy Chicago Cperations Cifice 9800 S. Cáss Rivenue

fijonne, IL 60439

\section{ONSITE}

5 CSE Richiand Operations

\section{Office}

P. D. lzatt

D. Crouter

D. C. Langstaff

O. L. 01 sen

J. J. Sutey

2 Rockwell_Hanford

Qperations

K. H. Henry

E. H. Randk 1 ev

\section{Pacific Northwest}

Laboratory

W. W. Ballard

J. L. Brajtrian

B. M. Cole

C. A. Counts

P. M. Daling (5)

J. F, Fletcher

R. J. Hall

G. M. Holter

J. D. Ludwick

A. T. Luksic

J. L. McEl roy

R. W. Mckee (10)

G. B. Mellinger

R. E. Rhoads

K. J. Schneijer

M. R. Shay

R. I. Smith

M. K. White

T. W. Hood

Publishing Cooroination (2)

Technical Information (5) 